\title{
A POLÍTICA DE CRÉDITO RURAL E A SUBORDINACGAO DA AGRICULTURA AO CAPITAL, NO BRASIL, NO PERIODO DE 1970-75
}

BASTIAAN PHILIP REYDON

Orientador: RODOLFO HOFFMANN

Dissertação apresentada ă Escola Superior de Agricultura "Luiz de Queirōz", da Universidade de São Paulo, para obtenção do título de Mestre em Agronomia, ārea de con centração: Economia Agrāria.

PIRACICABA

Estado de São Paulo-Brasil

Fevereiro, 1984 
As pessoas que sofreram as consequências do doloroso processo de Modernização da Agricultura Brasileira.

Para Helô e Patrĩcio por razões diversas que eles sabem. 
AGRADEÇO A

Rodolfo Hoffmann que com muita atenção e dedicação me orientou em minha formação na ESALQ e na elaboração deste trabalho.

FAPESP pelo incentivo financeiro.

Żi ida Paes de Barros Mattos e a Cicely M.Amaral pela leitura e atenta crîtica à versão original deste trabalho.

Josē Graziano da Silva pela oportunidade de participar de seu Projetos de Pesquisas.

Ziłmar, Taffner e Raimundo pela colaboração. 
INDICE

Pāgina

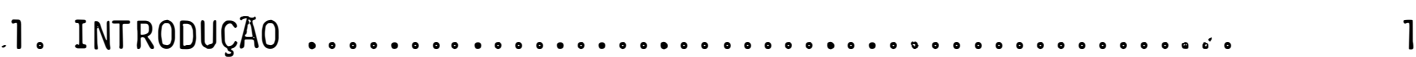

2. A MODERNIZAÇÃO CONSERVADORA E A SUBORDINAÇÃO DA AGRICULTURA ........................................ 3

2.1. Modernização Conservadora ..................... 3

2.2. Subordinação da Agricultura ao Capital ........... 6

2.3. Industrialização da Agricultura ............... 10

2.3.1. Industrialização da Agricultura Brasileira: Al gumas evidências ....................

2.3.1.1. Progresso Técnico por Estrato de Area ........................ 24

2.3.1.2. Progresso Técnico por Estado de Federação .....................

2.3.1.3. Uma Tentativa de Sỉntese do Progresso Técnico ................. 46

2.3.2. Alterações na Distribuição da posse da Terra 52

2.4. Resumo do Capîtulo ........................... 54

3. A POLITICA DE CREDITO RURAL ...................... 60

3.1. Crédito Rural - Principais Características ........ 66

3.1.1. O Crescimento dos Montantes Distribuídos ... 66

3.1.1.1. O val.or do crédito por hectare de lavoura....................... 68

3.1.1.2. 0 Crédito: o crescimento dos montantes ...................... 72

3.1.2. A Grande Concentração do Crédito Concedido . 74

3.1.3. O Direcionamento do Crédito para alguns Produtos .............................. 81

3.1.4. A Concentração Regional ............... 83

3.2. Resumo do Capítulo ....................... 84

4. A QUESTAOO DA ELEVAÇÃO DO PREÇO DA TERRA ............... 86

4.1. 0 Preço da Terra: Algumas Anālises ............. 87 
P.āgina

4.2. o Crescimento do Preço da Terra no Brasi1: uma con-

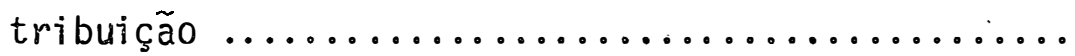

4.2.1. Um Estudo Econométrico para o Preço da Ter-

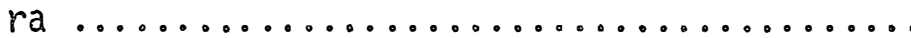

4.2.2. Algumas Conclusões acerca do Comportamento do Preço da Terra ........................ 105

5. CONSIDERAÇÕES FINAIS ....................... 107

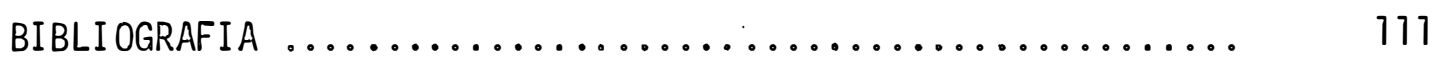

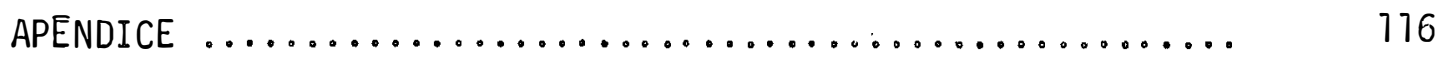


TABELA 2.1: Porcentagem do total de estabelecimentos que se utilizam de força humana, força animal, força mecānica, força animal e mecānica - Brasil, $1960-1970-1975(\%) \ldots \ldots \ldots \ldots \ldots \ldots \ldots$

TABELA 2.2: Porcentagem do total de estabelecimentos que se utilizam de arados de tração animal, arados de tração mecānica, tratores e colhedeiras - Brasil $-1960-1970-1975(\%) \ldots \ldots \ldots \ldots \ldots \ldots$

TABELA 2.3: Porcentagem do total de estabelecimentos que usam adubos, defensivos, terras irrigadas, trabalho temporärio, trabalho permanente e serviços de empreitada. Brasil 1970/1975 (\%) ......

TABELA 2.4: Pessoal ocupado na agricultura por categoria Brasil 1960, 1970, 1975 - Milhões de pessoas..

TABELA 2.5: Taxas médias de crescimento da produção, por Grupos de Produtos e Regiões, 1968/76 (\%) .....

TABELA 2.6: Taxas médias de crescimento da produtividade, por Grupos de Produtos e Regiões, 1968/76 (\%) .

TABELA 2.7: Area de Lavoura e Area Total para o Brasil 1950/60/70/75 e Taxas de Crescimento Anuais ...

TABELA 2.8: Rendimento por homem ocupado - Brasil - 1970/ 1975 - cr\$ 1.000 de $1977 \ldots . . . \ldots . . . . . . . . .$.

TABELA 2.9: Porcentagem de estabelecimentos que usam a força humana, animal, mecānica e animal e mecānica, Brasil 1970 e 1975 ......................... 
TABELA 2.10: Porcentagem de estabelecimentos que usam:tratores, arados de tração animal, arados de tração mecānica, colhedeiras, adubos e defensivos -

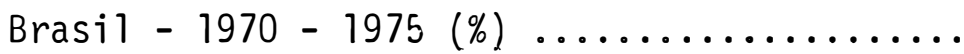

TABELA 2.11: Porcentagem de estabelecimentos que se utilizam de irrigação, trabalho temporário e trabaTho permanente. Brasil, 1970-1975 (\%) ......

TABELA 2.12: Média anual de força de trabalho em equivalentes - homem contratado por empreiteiros - Brasil - $1970-1975$........................

TABELA 2.13: Participação das categorias de trabalho no total de emprego. Brasil - 1970-1975 (\%) ......

TABELA 2.14: Número de pessoas das categorias de trabalho por estabelecimento e por unidade de área ocupada. Brasil - 1970-1975 - nümero de pessoas ...

TABELA 2.15: Uזilização de terras no Brasil 1970-1975 (\%).

TABELA 2.16: Porcentagem do total dos estabelecimentos que se utilizam dos diversos tipos de força - 17 Estados - 1970/1975 ........................

TABELA 2.17: Nūmero de máquinas e instrumentos por mi1 hectare de lavoura; porcentagem de estabelecimenios que se utilizam de adubos - 17 Estados -

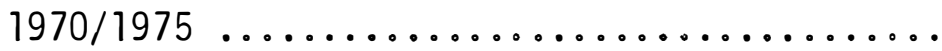

TABELA 2.18: Variações dos valores reais de despesas por hectare, 17 Estados - 1970 e 1975 ..........

TABELA 2.19: Porcentagem do total de pessoal ocupado - Algumas categorias - 17 Estados ...............

TAEELA 2.20: Valor da produção total por hectare de lavouraRendimento por homem empregado e pela área total - Cr $\$$ mil de $1977 \ldots \ldots \ldots \ldots . . . . . . .$. 
TABELA 2.21: Matriz de Correlações - Indicadores de capita1.ização e tecnificação 1970 - 17 Estados .....

TABELA 2.28: Matriz de Correlações - Indicadores de capitalização e tecnificação 1975 - 17 Estados ....

TABELA 2.23: Pesos dos Fatores do nỉvel de tecnificação 1970 - 11 variäveis para 17 Estados ..........

TABELA 2.24: Pesos dos Fatores de nỉvel de tecnificação 1975 - 11 variāveis para 17 Estados ..........

TABELA 2.25: Correlações do 10 componente principal com preço da terra, crëdito total e rentabilidade por homem empregado - 1970 e 1975 - 17 Estados ....

TABELA 2.26: Indice de Gini $\left(G^{*}\right)$ da distribuição da posse da. terra pelos estabelecimentos agropecuārios, no Brasil, por Unidades de Federação, de acordo

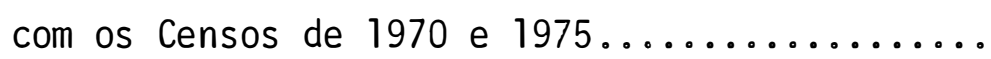

TABELA 2.27: Nīivel de Tecnificação e capitalização,obtido pelo método de componentes principais para 1970 e 1975 e sua taza de crescimento anual........

TABELA 3.1: Renda Interna do Setor Primārio e o Volume de Recursos concedidos pelo Sistema Nacional de Crédito Rural - 1969-1979 (Em Cr\$1.000.000) -

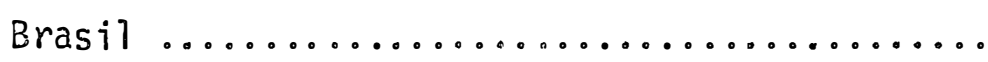

TABELA 3.2: Financiamentos concedidos à lavoura ..........

TABELA 3.3: Crëdito para lavoura por hectare de lavoura ... 
TABELA 3.4: Crédito Rural - Taxa Real de Crescimento Anual

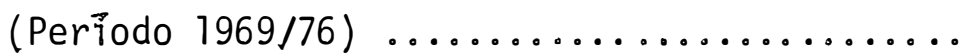

TABELA 3.5: Distribuição do Crēdito Rural do Banco do Brasil no Brasil e em alguns Estados - 1975: Indice de Gini (G), Indice de Theil (T), porcentagem do crédito agrīcola correspondente aos contratos menores do que a mediana (C50-) e aos maiores do que o $95^{\circ}$ percentil $(\mathrm{C} 5+)$, média (m) e a mediana (D) em salārios mīnimos .......

TABELA 3.6: Porcentagem de estabelecimentos que obtēm crēdito - 1970/1975

TABELA 3.7: Distribuição do Crēdito Rural do Banco do Brasil e em alguns Estados para 1975: Indice de Gini corrigido $\left(G^{\prime}\right)$ e Indice de Theil corrigido

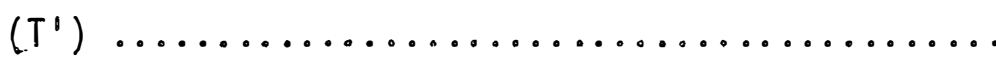

TABELA 3.8: Correlações entre grau de concentração do crēdito, os montantes de crédito por hectare, 0 nivel tecnolögico e a produtividade por homem empregado - 16 Estados - $1975 \ldots . . . . . .$.

TABELA 3.9: Participação do crëdito para certos produtos agrïcolas no total de crédito de custeio e participação do valor da produção desses mesmos produtos no valor bruto da produção total em $1975(\%)$

TABELA 3.10: Participação do Produto e do crédito agrĩcola das regiões brasileira no Produto Agrīcola Total e no Crēdito Agrīcola Total - 1975 - Porcentagem

TABELA 4. 1: Taxas geomëtricas anuais mëdias de crescimento do preço real da terra de lavoura - 1969/1976 17 Estados 
TABELA 4.2: Preço real de venda da terra de lavoura - 17 Es tados - 1970/1975 - Cr\$/ha de $1977 \ldots \ldots \ldots \ldots$

TABELA 4.3: Equação de regressão do preço da terra de lavoura em função do crēdito rural total - Coeficiente de correlação, Coeficiente de regres

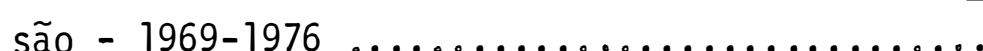

TABELA 4.4: Equações do preço da terra, Coeficientes de Regressão; Coeficientes de Determinação Mūitipla $\left(R^{2}\right)$; teste Durbin-Watson - 1970-1975 ....

TABELA 4.5: Correlações entre nīvel técnico e de capitalização com crēdito, preço da terra e rentabilidade da agroēcuāria - 1970-1975 - 17 Estados (preços correntes)

TABELA 4.6: Correlações entre crēdito à Agropecuāria, preço da terra de lavoura, rentabilidade da agropecuāria, preço de arrehdamento e urbanização - 1970 - 17 Estados - Preços correntes.....

TABELA 4.7: Correlações entre crëdito,preço da terra, rentạ bilidade da agropecuāria, preços de arrendamento e urbanização - 1975- 17 Estados - iPreços Correntes.

APENDICE

TABELA 1: Preço da terra de lavoura - 17 Estados, dezem

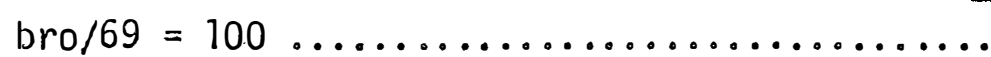

TABELA 2: $\quad$ Ocupação da fronteira em ha - 17 Estados

TABELA 3: Preço médio da terra - Brasil - 1970/1980 .....

TABELA 4: Crēdito total real concedido à agropecuäria 17 Estados - Dezembro/69 $=100$ 
GRAFICOS

GRAFICO 1: Evolução do īndice real de crēdito para a agropecuāria e do indice real do preço da terra - São Paulo $-1969=100$.

GRAFICO 2: Evolução do indice real de crëdito para a agropecuäria e do indice real do preço da terra - Alagoas $-1969=100$.

GRAFICO 3: Evolução do īndice real de crēdito para a agrop̄ecuāria e do indice real do preço da terra - Pernambuco $-1969=100$.

GRAFICO 4: Evolução do īndice real de crēdito para a àgropecuāria e do indice real do preço da terra - Bahia - $1969=100$. 
A POLITICA DE CREDITO RURAL E A SUBORDINAÇAO DA AGRICULTURA AO CAPITAL, NO BRASIL, NO PERÍODO DE 1970-75

\author{
CANDIDATO - BASTIAAN PHILIP REYDON \\ ORIENTADOR - RODOLFO HOFFMANN
}

\title{
RESUMO
}

0 presente estudo procura analisar o papel exercido pela política de crédito agrīcola nas transformações do setor rural durante a primeira metade da década de 70, observando-se basicamente como estas transformações viabilizam o processo de subordinação da agricultura ao capital, isto é, como surgiu na agricultura um profĩcuo espaço de aplicação de capitais.

$$
\text { Utilizamos, para este estudo, outras anālises sobre }
$$
questão e suas fundamentações teōricas; a apreciação de tabelas e gräficos; e métodos estatî́sticos tais como: correlações, regressões simples e mültiplas e o método de componentes principais.

Pudemos observar inicialmente que houve na agricultura brasileira, no perīodo 1970 a 1975, um intenso processo de elevação do uso de tecnologia moderna, havendo indicações de que o crédito rural tenha sido o grande indutor destas transformações.

$$
0 \text { maior uso de tecnologia parece ter estado intimamente }
$$
ligado à elevação da produtividade por homem empregado e aos grandes es:tabelecimentos, apesar de ter havido modernização entre pequenos estabelecimentos.

Evidenciamos que a expulsão do homem do campo, o aumento da concentração da posse de terra, mudanças na utilização da força de trabalho (surgimento do bóia-fria) e a acentuada el evação do preço da terra, foram, entre outras, as principais conseqüências do processo de mödernização da agricul tura brasileira. 
Fato que mereceu destaque no estudo foi a acentuada elevação do preço da terra rural no perỉodo 69/75, dada a importância que esta variável assume no setor rural e na interação com a economia como um todo. Constatou-se uma intensa relação entre a recente elevação do preço da terra rural e o crédito rural concedido.

0 estudo da acentuada ei evação do preço da terra nos indica que esta se origina tanto de um processo especulativo com terras e com crédito, quanto da el evação da utilização de tecnologia, que também ocorre com uma intensa participação da polîtica creditîicia.

Pudemos observar, ainda, que a acentuada elevação do preço da terra acabou por ser um importante catalizador do aumento c'a concentração da posse da terra e da riqueza na agricultura brasileira.

Por fim, pudemos concluir que tanto a modernização da agricultura, quanto suas principais consequenncias tem sido um importante elemento para o processo de subordinação da agricultura ao capital, no sentido de viabilizar o campo como um espaço da reprodução e da ampliação do capital. 
THE RURAL CREDIT POLICY AND THE RURAL SECTOR SUBORDINATION TO CAPITAL IN BRAZIL - 19:70/75。

\author{
CANDIDATE - BASTIAAN PHILIP REYDON \\ ORIENTATION - RODOLFO HOFFMANN
}

SUMMARY

The present study analises the role that the Rural credit Policy has had in the rural sector transformations, in Brazil, during the first half of the seventies. Special care has been taken in observing how these transformations have brought about the subordination of the rural sector to capital; in other words, how those transformations have opened a new range of possibilities for capital aplications.

In this study, we have used a) other analises about this matter, and their theoretical foundations; b) the analises of tables and diagrams; and c) statistical methods as: correlations, simple and multiple regressions and the method of principal components.

First of all we observed an intensification in the use of modern technology in the period of 1970 to 1975. There are indications that these transformations had the rural credit as their major promoter.

There is evidence that the use of modern technology has been linked to the increase of labor productivity, especially in large farms. But we have also noticed an increasing use of modern technology in some small farms.

We have seen that the recent modernization in Brazilian agriculture has brought some very important consequences as: the pushing out from agriculture of small farmers and farm labour, changes in the utilization of man power, stronger concetration of land property and a sharp increase of land price. 
A matter we gave special attention to, is the great increase of land price, in Brazil, because of its importance in the rural sector organization and its interaction whith the economy as a whoie. In this study we have also observed a great correlation between the increase of land price and the rural credit obtained.

The analysis of the sharp increase of the land price has shown that it was derived from a speculative process with land and rural credit (and its speculative use), as well as with the increase of the utilization of technology.

We have arso noticed that this land price increase had a special role in strengthening the concentration of 1 and property and wealth.

Finally, we were able to infer that the agriculture modernization, as well its main consequences, have been an important element in the process of agriculture subordination to capital, in the sense of creating conditions for capital reproduction and its accumulation in agriculture. 


\section{INTRODUÇÃO}

A. Política de Crédito Rural tem sido objeto de inúmeros estudos. Isto se deve ao fato de que esta política assumiu, dentro do desenvolvimento da agricultura, um papel fundamental, papel esite que passou a ser objeto de controvērsia. Alguns autores entendiam que a política de crédito rural era o principal elemento para viabilizar o rompimento dos laços tradicionalistas. Outros colocavam que a política, alēm de ser ineficiente em termos da elevação da produtividade, somenté possibilitava um ganho excedente para uma pequena parte dos produtores!

Neste sentido procuramos, neste trabalho, compreender 0 papel que esta política exerceu durante a período. 1970/75 no Brasil.

No discurso oficial hă a colocação de que o crédito rural visava a modernização, a integração e a melhoria do nível de vida dos pequenos produtores. Procuramos, entretanto, captar quais foram as consequências desta polîtica, a um nîvel mais estrutural.

A partir do entendimento de que a agricultura está inserida no contexto de uma economia que se caracteriza pelo desenvolvimento capitalista tardiol, esta agricultura se transformarā sintonizada com este desenvolvimento mais global. 
A transformação da agricultura constitui-se numa abertura que viabiliza, tambēm neste setor, o processo de valorização do va1or. Desenvolve-se, assim, o processo de subordinação da agricultura ao capital, que no Brasil se deu atravēs da Modernização Conservadora.

No Capítulo 2 procuramos desenvolver, sob um prisma global, o processo de subordinação da agricultura integrando-o à Modernização Conservadora. Mostramos como a industrialização do campo, viabilizada pela política de crédito agrícola, foi o principal motor da Modernização Conservadora.

No Capítulo 3 desenvolvemos um estudo acerca de como a política de crédito agrícola foi implementada, no período 1970-1975 no Brasil. Analisamos a forma que esta política assumiu e quais foram suas principais consequências. Entre as consequências da política de crédito agrīcola, destacamos a elevação acentuada do preço da terra.

Neste sentido, no Capítulo 4 procuramos desenvolver um estudo sobre o preço da terra, desde alguns aspectos teóricos atē uma anālise econométrica: sobre os principais fatores associados à formação do preço da terra.

Jā no Capítulo 5 procuramos sintetizar as principais conclusões a que o estudo conduz.

Por outro lado, procuramos, conjuntamente com a visão global da realidade, realizar uma série de estudos quantitativos, na tentativa de retificar. ou ratificar nossas concepções teōricas acerca desta mesma realidade. 
2. A MODERNIZAÇÃO CONSERVADORA E, A SUBORDINAÇAO DA AGRICULTURA

Neste capítulo pretendemos caracterizar a Modernização Conservadora como sendo a forma encontrada pelo capitalismo brasil eiro para subordinar a agricultura ao capital. Mostramos também que nesta Modernização Conservadora o Estado tem um papel preponderante.

\subsection{Modernização Conservadora}

Com o novo padrão de acumulação que se estabeleceu partir dos anos cinquenta, grandes alterações ocorreram no setor urbano da economia brasileira. Houve um incremento acentuado na produção industrial e na urbanização. A agricultura, basicamente atravēs da expansão de áreas, pode continuar a cumprir seus papēis principais, sem grandes alterações. Atē o final dos anos cinquenta, "o setor agrīcola não dependia, no seu processo produtivo, da indūstria: as técnicas de cultivo eram primitivas, e o emprego das máquinas, implementos e $e^{-i n s u-~}$ mos de origem industrial não era a regra. Entretanto, a agricultura desempenhava papēis de grande importância para a economia e, particularmente, para a acumulação na indūstria: fornecia divisas para a importação de bens de produção, era uma fonte de financiamento da acumulação atravēs de confisco cambial, produzia alimentos para a produção da força de trabalho urbana, que, em sua maior parte, veio do setor rura1. Pode-se afirmar, assim, que a produção industrijal dependia em boa medida do comportamento do setor agrî́cola, mas este, na esfera estri- 
tamente produtiva, pouco necessitava da indūstria"l.

A partir dos anos 60 surge também na agricultura um pro cesso de intensificação da produção, aliado a um processo de subordinação deste setor às necessidades de acumulação do capital. Esta mudança no sistema produtivo agrīcola ganha maior intensidade a partir dos anos setenta. Dā-se o nome de "Modernização Conservadora" a este processo, posto que ele, através de mecanismos geridos pelo Estado ${ }^{2}$, possibilita uma subordinação crescente do setor rural, com introdução de modernas técnicas, sem alterar previamente a estrutura fundiäria. A princīpio, este processo visava a modernização do latifúndio, para sua transformação numa grande empresa agrīcola. Mais recentemente tem-se dado concomitantemente um processo de tecnificação da pequena produção.

A "Modernização Conservadora" 3 se define enquanto mode1:0 de desenvolvimento para a agricultura apōs o pacto político que é selado no golpe de 1964, do qual participaram a burguesia nacional, as oligarquias agrārias e o capital internacional, alijando as classes trabalhadoras urbanas e rurais de qualquer participação.

Esta forma de modernização da agricultura tem no Estado o seu principal elemento indutor. Neste processo de transformação da agricultura num setor subordinado ao capital houve a implementação de

\section{${ }^{1}$ INCRA/UNICAMP (1978).}

2 Para maiores detalhes de como o Estado participa do processo de indução da subordinação vi de UNICAMP/FINEP (1981):

${ }^{3}$ Há uma discussão bastante pertinente a respeito da expressão "Modernização Conservadora", que segundo alguns autores não identifica claramente o processo de mudança que houve no setor rural. Entendemos que, na medida em que houve um processo de transformação da agricultura, que alterou no seu decurso tanto a estrutura fundiāria, quanto as relações de produção no setor, este não è um processo conservador. Dada a utilização comum da expressão, visando caracterizar o fato de que a agricultura passou por uma modernização que manteve e até aprofundou a dicotomia entre possuidores e não-possuidores dos meios de produção, enteridemos que sua utilização é vālida, apesar de salientar que, em alguns aspectos, o processo pode até ser considerado revolucionário. 
seis principais politicas, geridas pelo Estado:

1. Politica de crédito subsidiado

2. Politica de incentivos fiscais

3. Política de colonłzação

4. Política de preços mínimos

5. Política de comercialização

6. Política de assistēncia técnica.

Estas politicas tem um papel fundamental no processo de subordinação da agricultura, que no Brasil assumiu a forma da Modernização Conservadora. De uma forma simplificada podemos colocar que os incentivos fiscais se prestaram à ocupação da fronteira agrícola por parte de grandes empresas agrícolas. A política de colonização, per sua vez possibilitou a ocupação de pequenos espaços definidos da fronteira, com os pequenos produtores expulsos das regiões onde a modernização se dava, evitando graves conflitos sociais.

Por outro lado, a política de preços mínimos, apesar de pouco efetiva durante os anos 70, garantiu um espaço para o Estado como regulador do mercado agrícola. A política de comercialização, basicamente com a criação da COBAL e do CIBRAZEM, viabilizou uma integração entre a produção de bens agrícolas de consumo interno e o mercado. Mas esta integração passou a ser dominada por pequeno número de grandes comerciantes, que obtem altos lucros na comercialização destes bens.

A polîtica de Assistência Técnica, gerida pela EMBRATER / ABCAR, a nível nacional, visava basicamente difundir ao produtor a produ ção agrícola tecnificada, modernizada e mercantilizada. Tudo nos leva a crer que teve um papel bastante significativo na subordinação da agricul tura brasileira.

Hā indicações de que a Modernização Conservadora apesar de necessitar destas políticas acima arroladas, não seria viāvel sem a política de crédito. Pois, a polītica de crédito, como procuraremos mostrar nos capítulos subsequentes, ao fornecer recursos a baixo custo aos produtores, viabilizou uma produção mais tecnificada, integrada e mercantilizada. 


\subsection{A Subordinação da Agricultura ao Capital}

Dentro do conceito de Modernização Conservadora utilizamo-nos da idēia de subordinação da agricultura ao capital. Cabe explicitar o que entendemos por isso.

Para tal, devemos voltar ao conceito de Marx de que a essência do modo de produção capitalista é a valorização do valor. Para que o capitalismo possa persistir nesse processo de valorização do valor, que è um processo contīnuo e dinâmico, cada vez mais a produção tem de ser subordinada a ele. Como coloca Sergio Silva (1981, pp. 38), "a submissão da produção à lei do valor è, na verdade, a submissão da produção ao capital".. E dentro deste movimento devemos entender a agricultura passando de uma forma de produção na qual sua inserção no conjunto da economia dava-se basicamente atravēs da venda de sua produção, para uma produção mais integrada e determinada pelos demais setores da economia.

Colocando de forma mais clara, a submissão da produção à lei do valor ou, em outro nível, ao capital é um processo no qual este capital busca novos espaços para sua atuação e para sua valorização. Processo este que é a essência da dinämica do modo de produção capitalista e que hoje atinge de forma marcante a agricultura brasileira.

Neste sentido, a industrialização da agricultural $\bar{e} 0$ principal mecanismo deste processo de subordinação. Pois, com a industrialização, ou seja, maior utilização de insumos e de tecnologia mo-

\footnotetext{
${ }^{1}$ Uma definição especîfica de industrialização da agricultura encontramos em Tikhonov (1978). "Estes processos (total mecanização, amplo emprego da moderna genetica, etc.) em sua totalidade determina a transformação da agricultura em produção industrial que se caracteriza por um elevado grau de especialização e concentração, a diminuição e a subsequente eliminação da dependencia da agricultura do acaso e da espontaneidade da ação das forças naturais (...) o incremento do grau de continuidade e do ritmo da produção e na estabilidade das taxas de seu desenvolvimento". Mas este processo alēm de requerer prévias condiçöes para se efetivar, acaba por transformar significativamente as relações sociais de produção vigentes na agricultura.
} 
derna (física ebiológica), há uma maior possibilidade de subordinar tan-to o trabaltio quanto a terra às necessidade da acumulação do capital.

A expansão do compiexo agroindustrial, isto é, "o conjunto formado pelos setores produtores de insumos e maquinarias agrícolas, de transformação industrial dos produtos agropecuārios e de distribuição, e de comercialização, e de financiamento nas diversas fases do circuito agroindustrial" Sorj (1980, p. 29), tem um papel fundamental no processo de subordinação da agricultura. Na medida em que o complexo agroindustrial opera em todos estes setores, viabiliza um maior domínio por parte deste capital sobre a produção agrīcola. Devemos ter em mente que se este processo de transformação industrial fosse dominado por cooperativas, que não assumissem o papel de empresas capitalistas, nos quais os interesses dos pequenos agricultores fossem respeitados, terỉamos uma forma bastante distinta de subordinação da agricultura.

Ulma outra faceta desta subordinação ē o prōprio domīnio que o capitai passa a ter sobre o processo produtivo. Como exemplo disso podemos colocar a usina do setor canavieiro que passa a determinar o montante e a qualidade da produção, assim como os insumos e instrumentos que os fornecedores tem que utilizar. Esta caracterīstica è bastante marcante para vārias atividades agropecuārias, como a cultura do fumo e a criação de suĩnos, entre outras. Também na maior parte das coope rativas agrícolas faz-se presente a dominação destas sobre a produção dos cooperados, no sentido de sua subordinação. 1 Esta faceta da subordinação estā claramente vinculada à necessidade que o capital tem de homogeneizar a produção para a sua maior integração na produção capitalista e para que participe mais intensamente do processo geral de acumulação.

Não pretendemos aqui aprofundar muito a questão da subordinação, posto que este não $\bar{e}$ o objetivo deste trabalho. Desejamos apenas colocar que este processo estā em curso e caracterizar sua forma geral.

'Maiores detalhes acerca do papel das cooperativas agrỉcolas no capitalismo Brasileiro são apresentados por LOUREIRO (1981). 
Para GRAZIANO DA SILVA (1980) a subordinação da agrícultura ao capital dá-se via industrialização da agricultura, na medida em que esta subordinação ē o processo de subsunção do trabalho e da terra ao capital. E a industrialização da agricultura permite a sua subsunção, como veremos mais adiante.

Dentro do processo de subordinação da agricultura, a mercantilização da produção assume um papel de vital importāncia. Sem a mercantilização da agricultura, o processo de industrialização e a subordinação não seriam possīveis. Mas somente a mercantilização não viabiliza uma completa subordinação. LENIN (1979, p. 301) nos apresenta uma definição bastante clara do que ē mercantilização da agricultura: "El incremento de la agricultura mercantil crea mercado interior para el capitalismo. En primer lugar, la especializaciōn de la agricultura provoca el intercambio entre las diferentes zonas agrĩcolas, entre las diversas haciendas agrīcolas y entre los diversos productos del campo. Em segundo lugar, cuanto más se adentra la agricultura en la circulaciōn mercantil tanto más rapidamente crece la demanda de productos de la indūstria transformativa, que sirven para el consumo personal, por parte de la poblaciōn del campo; con tanta más rapidez, en tercer lugar, crece la demanda de médios de producciōn (...)".

No nosso entender a subordinação da agricultura ao capital é mais do que o processo de industrialização ou de "mercantilização" acentuada da produção. E o processo pelo qual a agricultura transforma-se para possibilitar a entrada do capital, no setor agrícola, enquanto valor que se valoriza. As modificações das relações de produção no setor agrícola, incluindo-se a perda de autonomia dos pequenos produtores, são o cerne do processo de subordinação da agricultura. A pequena produção passa crescentemente a ser determinada exogenamente (basicamente pelo grande capital e pelo Estado): os produtos a serem produzidos, como produzir estes produtos, e que tipos de instrumentos utilizar. Isto quando esta categoria de produtores consegue se manter como proprietāria de terras.

Mas o principal motor deste processo de subordinação ē a prōpria industrialização da agricultura que, alēm de ser estabelecida de acordo com às necessidades de acumulação do grande capital, visando

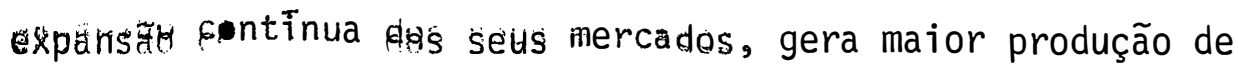
exce- 
dente na economia como um todo.

A vịabilízação da subordinação, fundamentalmente atravēs da industrialização, acaba por transformar significativamente a agricultura.

As características do modelo brasileiro, a partir de 1964, fazem com que os processos de subordinação e industrialização da agricultura sejam crescentemente geridos e orientados pelo Estado. E a principal politica adotada pelo Estado brasileiro neste processo foi a política de crédito rural subsidiado.

A polītica de crédito, na medida em que è a concessão de capital a juro subsidiado para algumas culturas predeterminadas, não deixa de ser uma forma de subordinar a produção agrīcola às necessidades de acumulação do capital.

Esta subordinação assume uma forma mais grave quando se observa que às vezes os produtores vendem sua colheita em fase de preços mais baixos apenas para poderem saldar sua divida com o Banco, normalmente para poderem contrair novo empréstimo.0 produtor torna-se assim, um eterno dependente da polîtica de crédito rural.

As formas indiretas de subordinação atravēs do crédito, se dão pela compulsoriedade de aquisição de certos pacotes tecnológicos e/ou montantes de adubos, com a obtenção do crédito.

Não podemos deixar de levar em conta que a própria industrialização da agricultura foi sustentada pelo crédito subsidiado.

Por outro 1ado, como pretendemos demonstrar ao longo deste estudo, o crédito na maneira como foi concedido possibilitou uma elevação acentuada do preço da terra assim como a prōpria concentração da produção e da propriedade da terra. Estes tambēm são elementos que tem uma importāncia fundamental no processo de subordinação da agricultura ao processo de acumulação capitalista. 


\subsection{A Industrialização da Agricultura ${ }^{1}$}

A principal forma de subordinação da agricultura ao capital é através de sua industrialização. Neste processo a subordinação se dá pela sujeição do trabalho e da terra ao capital atravēs da potenciação destes elementos.

A potenciação do trabalho se dā basicamente atravēs da utilização de inovações mecânicas, que possibilitam ao capital, além da ob.tenção de mais valia relativa, submeter 0 trabalho às suas necessidades $^{2}$.

Por outro lado, a potencialização da terra pode ser observada nas inovações biolōgicas e físico-quīmicas. Estas possibilitam desde a elevação da produtividade da terra atē uma melhor integração com as inovações mecânicas, subjugando as condições naturais da terra às necessidades do processo de acumulação.

0 que deve ser salientado è que o processo de industrialização não visa a elevação da produção e da produtividade do trabalho e da terra em si, mas busca, através destes mecanismos, fazer com que o processo de produção agrî́cola torne-se mais subordinado às necessidades de acumulação. 0 caso da colheita mecânica deixa isso bem claro, posto que, para alguns produtos, tecnicamente, a produçăo poderia ser totalmente mecanizada, mas continua a ser mais lucrativa a utilização do trabalho manual para este fim.

Um elemento fundamental $\overline{\mathrm{e}}$ que estas potenciações, tanto da terra quanto do trabalho, acentuam-se quando utilizadas conjuntamente. E muitas vezes, a utilização de uma inovação, para a obtenção de sua eficiência máxima, requer a utilização simultānea de outras inovações.

IMaiores detalhes vide GRAZIANO DA SILVA (1980)

${ }^{2}$ Para um estudo mais aprofundado dos efeitos da mecanização sobre a utilização da força de trabalho vide UNICAMP/FINEP (1981:). 
Esta industrialização da agricultura, ao elevar a produção e a produtividade tanto do trabalho quanto da terra, através da expansão no uso de tecnologia moderna, gera um aumento na demanda por bens industriais por parte do setor agrīcola. Dessa maneira, a expansão da agricultura se dā de uma forma mais subordinada e integrada ao setor dinâmico da economia.

A observação dos tipos de cultura que mais se modernizaram fornece claras indicações de como esse processo está altamente integrado. Is to $\bar{e}$, as culturas como o café, soja, trigo e cana, normalmente ligadas às exportações ou às agroindústrias foram ás mais modernizadas. Mais recentemente observamos a modernização de algumas culturas de consumo interno, indicando que houve necessidade de subordinar este setor da agricultura, para o processo geral de acumulação capitalista.

\subsubsection{Industrialização da Agricultura Brasileira: Algumas evidências}

Pretendemos nessa seção apenas mostrar que houve um processo bastante acentuado de incorporação de técnicas modernas no setor rural durante o quinquênio 70/75. Talvez esse processo esteja bem aquém do que possibilitaria o elevado montante de recursos distribuỉdos pelo crédito, mas esta argumentação, no nosso entender ${ }^{1}$, não invalida o papel que a política de crēdito teve no processo de subordinação da agricultura. Como veremos no capítulo que se segue, esta politica teve distintos papēis no processo de subordinação, um deles sendo a industrialização da agricultura.

Inicialmente faremos um estudo que abarque o Brasil como um todo, a fim de caracterizar as transformações que ocorrem durante 0 perīodo 60/75. Em seguida, mostraremos que tipo de propriedade, em termos de ārea total, mais incrementou o uso de tecnologia. 
Devemos ressaltar que os dados aqui utilizados são oriundos dos Censos Agropecuārios e que o conceito de estabelecimento não é sempre o mesmo. Os Censos de 1960 e 1970 determinam que estabelecimento $\bar{e}$ composto apenas pelas āreas contīnuas, ou seja, se hā um proprietārio com terras não contĩnuas, cada uma das āreas ē um estabelecimento. Jā no Censo de 1975 o conceito de estabelecimento inclui as āreas descontínuas, de maneira que todas as āreas localizadas em um setor censitārio, mesmo que descontinuas, sob a mesma administração são consideradas um ūnico estabelecimento. Estas ressalvas são importantes para anālises sobre a estrutura fundiāria, mas para o que pretendemos analisar este aspecto tem pequena interferêncial.

Ao anậisarmos a modernização da agricultura no Brasil devemos observar que este não é um processo contīnuo, mas sim, como coloca GRAZIANO DA SILVA (1980 a, p. 57), "a agricultura brasileira espelhava avanços e recuos de uma lenta e, por isso mesmo, dolorosa modernização, essa em sua maior parte sustentada "artificialmente" pelos generosos subsīdios estatais". Alēm disso, hā as grandes diferenças regionais, onde uma grande modernização para a produção de feijão no nordeste pode ser a utilização de arado a burro, ou mesmo a condição de se utilizar mais mão-de-obra, enquanto no sudeste a modernização está mais vinculada à utilização de implementos, de mão-de-obra temporāria e de adubos químicos.

Apesar das diferenças regionais, podemos notar, a partir da TABELA 2.1.,que hā um processo de Modernização no paīs como um todo. do: A quantidade de estabelecimentos que se utilizam apenas de força humana diminui significativamente entre 1960 e 1975. Pode-se notar que a Modernização, a partir de 1970, tem um carāter bastante marcante, pela observação dos dados de força animal e força mecānica. Somente entre 1970 e 1975 o número de estabelecimentos que se utilizam de força animal diminuiu, enquanto que o incremento na utilização de força mecãnica a partir de 1970 é bastante grande.

\footnotetext{
IPois se houve um pequeno decréscimo no nūmero total de estabelecimentos, também diminuirā o número de estabelecimentos que se utilizam das técnicas modernas, mantendo a proporção.
} 
Não devemos nos surpreender com os incrementos do uso da força mecânica que, apesar de serem significativos, espelham claramente o quanto pouco modernizada ainda se apresenta a agricultura brasileira.

No que se refere à porcentagens de estabelecimentos que se utilizam dos diversos tipos de máquinas e implementos, observamos, na TABELA 2.2, que comparativamente ao perỉodo 60/70, no quinquênio 70/ 75 houve um crescimento bastante acentuado deste uso, exceto no que se refere aos arados de tração animal e às colhedeiras. E esperado que a utilização do arado de atração animal decresça, pois é uma forma arcaica de potenciar a força de trabalho. 0 fato de a proporção de estabelecimentos que se utilizam de colhedeiras ter diminuĩdo neste perĩodo de tempo, alēm de advir de problemas de dados que jā foram discutidos, parece estar ligado à questão de que, dadas as dificuldades tēcnicas de mecanizar a colheita, e com a formação de um mercado de trabalho volante (os böias-frias), não houve necessidade tão preemente de ocorrer sua mecanização.

Os dados referentes à subordinação da terra são relativamente escassos, mas a TABELA 2.3 nos dá indicações de que a utilização de defensivos é bastante difundida a nivel dos estabelecimentos. Os defensivos assumem um papel cada vez mais importante à medida que novas variedades mais produtivas são criadas, e são cultivadas em condições que os tornam mais suscetiveis a pragas e doenças. 0 aumento da utilização de adubos e de irrigaçãol ${ }^{1}$ é bastante significativo no perỉodo $70 / 75$ dando clara indicação de que a potenciação da terra tem sido um mecanismo de fundamental importāncia para a subordinação da terra ao capital.

\footnotetext{
${ }^{1}$ A questão das sementes selecionadas não e analisada por não haver informação no Censo, mas esta também è, conjuntamente com os adubos ede.fensivos, uma forma fundamental de subordinação da terra ao capital.
} 
TABELA 2.1 - Porcentagem do total de estabelecimentos que se utilizam. de força humana, força animal, força mecânica, força animal e mecãnica - Brasi1, 1960 - 1970 - 1975 (\%)

\begin{tabular}{lccc}
\hline & 1960 & 1970 & 1975 \\
\hline Sö força humana & 76,6 & 65,8 & 60,1 \\
Força animal e humana & 22,0 & 27,9 & 25,4 \\
Força mecānica e humana & 0,5 & 2,3 & 8,6 \\
Força anima 1, mecânica e humana & 0,9 & 3,9 & 5,8 \\
\hline
\end{tabular}

Fonte: CENSOS AGROPECUARIOS 1960, 1970 e 1975

TABELA 2.2 - Porcentagem do total de estabelecimentos que se utilizam de arados de tração animal, arados de tração mecânica, tratores e colhedeiras - Brasil - 1960 - 1970 - 1975 (\%)

\begin{tabular}{lccc}
\hline & 1960 & 1970 & 1975 \\
\hline Arado tração animal & 18,2 & 23,1 & 23,3 \\
Arado tração mecânica & 3,0 & 2,0 & 3,8 \\
Tratores & 1,3 & 2,4 & 4,3 \\
Colhedeiras & - & 1,5 & 1,3 \\
\hline
\end{tabular}

Fonte: CENSOS AGROPECUARIOS 1960, 1970 e 1975. 
Uma discussão bastante importante, relacionada com 0 processo de industrialização, refere-se à utị ização de mão-de-obra nas suas diversas formas. Apesar dos dados do Censo não serem muito precisos neste āmbitol', a TABELA 2.4 nos dā indicação de que o nūmero de trabalhadores permanentes, apōs uma queda no perīodo 60/70, aumentou substantivamente entre 70 e 75. Isto se deve 'à transformação do antigo assalariado permenente (tipo colono) em trabalhador volante no perīodo 1960-1970. A partir de 1970.com a acentuada utilização de maquinarias e instrumentos, hā a necessidade de nova contratação de assalariados permanentes elevando sua participação na P.E.A. da agricul tura. Por outro 1ado, no processo de subordinação da agricultura ao capital, não tem sido um elemento fundamental a transformação dos responsāveis e dos membros não remunerados da famīlia em assalariados.: A tese de expropriação de pequenos produtores pelo capital tem sido avidamente defendida por alguns autores², como forma básica do avanço do capital sobre o campo. No nosso entender, as informações da TABELA 2.4 nos dão indicações de que a industrialização da agricultura, apesar de a longo prazo expropriar certo número de pequenos produtores, visa mais a sua subordinação via tecnificação ${ }^{3}$.

Mas o que de fundamental podemos captar è que a modernização da agricultura, que observamos, não tem intensificado a utilização de mão-de-obra. De acordo com os Censos Demogrāficos, em 1970. a População Economicamente Ativa do setor agrĩcola era de 13.090 mil pessoas, enquanto em 1980 atingia apenas $13.109 \mathrm{mil}$ pessoas. Isto nos mostra que houve uma saîda bastante acentuada de pessoas do campo para as cidades, que parece não ter comprometido a produção, caracterizando o desenvolvimento de uma agricultura com menor utilização de trabalho

\footnotetext{
${ }^{1}$ Nos dados do Censo não estão incluĩdos os trabalhadores temporārios por empreitada coletiva (bōias-frias), não sendo possîvel portanto, uma anālise mais detalhada acerca do assunto, jā que este $\bar{e}$ um dos trabalhadores que mais tem participado da produção. Maiores detalhes acerca deste assunto vide GRAZIANO da Silva, J. e KAGEYAMA, A. (1983).

${ }^{2}$ Entre eles encontramos SANDRONI (1980).
}

${ }^{3}$ No item seguinte deste capitulo procuraremos mostrar isto com mais pormenores. 
TABELA 2.3 - Porcentagem do total de estabelecimentos que usam adubos,. defensivos, terras irrigadas, trabalho temporário, trabaTho permanente e serviços de empreitada - Brasil - 1970/ $1975(\%)$

\begin{tabular}{lccr}
\hline & 1960 & 1970 & 1975 \\
\hline Adubos & 13,2 & 15,4 & 22,3 \\
Defensivos & - & - & 51,0 \\
Terras irrigadas & 1,0 & 2,1 & 3,0 \\
Trabalho temporärio & - & 7,6 & 8,0 \\
Trabalho permanente & - & 7,2 & 7,8 \\
Empreitada & - & 20,0 & 17,8 \\
\hline
\end{tabular}

Fonte: CENSOS AGROPECUARIOS 1960, 1970 e 1975.

TABELA 2.4 - Pessoal ocupado na agricultura por categoria Brasil 1960, 1970, 1975 - Milhões de pessoas

\begin{tabular}{|c|c|c|c|}
\hline & 1960 & 1970 & 1975 \\
\hline $\begin{array}{l}\text { Responsável e membros não remune- } \\
\text { rados da famîlia }\end{array}$ & $\begin{array}{c}7,85 \\
(63,0 \%)\end{array}$ & $\begin{array}{l}14,17 \\
(80,3 \%)\end{array}$ & $\begin{array}{l}16,37 \\
(80,4 \%)\end{array}$ \\
\hline $\begin{array}{l}\text { Empregados em trabalho permanen- } \\
\text { te }\end{array}$ & $\begin{array}{l}1,43 \\
(9,1 \%)\end{array}$ & $\begin{array}{l}1,16 \\
(6,6 \%)\end{array}$ & $\begin{array}{l}1,55 \\
(7,6 \%)\end{array}$ \\
\hline $\begin{array}{l}\text { Empregados em trabalho temporā- } \\
\text { rio }\end{array}$ & $\begin{array}{c}2,98 \\
(19,2 \%)\end{array}$ & $\begin{array}{l}1,49 \\
(8,5 \%)\end{array}$ & $\begin{array}{l}1,70 \\
(8,3 \%)\end{array}$ \\
\hline TOTAL & $\begin{array}{l}15,63 \\
(100 \%)\end{array}$ & $\begin{array}{l}17,58 \\
(700 \%)\end{array}$ & $\begin{array}{l}20,35 \\
(100 \%)\end{array}$ \\
\hline
\end{tabular}

Fonte: CENSOS AGROPECUARIOS 1960, 1970 e 1975. 
Um aspecto bastante controverso da industrialização da agricultura se relaciona ao fato da elevação da produtividade da terra ter sido bastante inexpressiva.

As TABELAS 2.5 e 2.6 nos dão uma clara amostra de que apesar de ter havido uma elevação da produção entre 1968 e 1976 pará quase toda as regiões e tipos de produtos, o mesmo não se observa em termos da produtividade da terra. Isto é, a ārea cultivada sofreu um incremento bastante acentuado. Por outro 1ado, na TABELA 2.6 podemos observar um crescimento da produtividade nas culturas de exportação apenas no NE e em São Paulo. Apesar da produção de produtos domésticos em São Paulo não ter apresentado crescimento, sua produtividade se elevou, podendo-se portanto concluir que sua área decresceu significativamente. Isto é, as āreas de culturas domésticas em São Paulo decresceram, mas a elevação da produtividade fez com que a produção permanecesse constante.

Jā o Nordeste observou um decrescimo bastante acentuado da produtividade por hectare dos produtos domésticos, enquanto os de exportação apresentaram um crescimento bastante razoável.

Em termos de Brasil as taxas de crescimento de 9,09 e 3,32 respectivamente dos produtos exportáveis e domésticos indicam que inclusive, a nỉvel da produção, os exportāveis apresentaram um maior crescimento. No que se refere à produtividade da terra, tanto os exportáveis como os domésticos apresentaram taxas de crescimento estatisticamente iguais a zero.

Neste sentido podemos concluir que no perīodo 1968/76, apesar das diferenças regionais e do crescimento da produtividade dos produtos exportáveis e domésticos em São Paulo, a produtividade por hectare dos exportāveis e domésticos não atingiu, a nīvel de Brasil, uma taxa de crescimento significativamente diferente de zero. 
TABEL.A 2.5 - Taxas médias de crescimento da produção, por grupos de produtos e regiões

$(\%)$

1. Exportāveis - Nordeste

5,77

2. Exportáveis sem café - Nordeste

5,38

3. Domésticos - Nordeste

$0,00^{\mathrm{a}}$

4. Exportāveis - Centro-Sul

12,51

5. Exportāveis sem café - Centro-Sul

18,55

6. Domésticos - Centro-Sul

5,01

7. Exportāveis - São Paulo

12,88

8. Exportāveis sem cafē - São:Paulo

6,63

9. Domésticos - São Paulo

$0,00^{\mathrm{a}}$

10. Exportāveis - Brasil

9,09

11. Exportāveis sem café - Brasi1

9,79

12. Domésticos - Brasil

3,32

13. Total - Brasil

5,11

Fontes: FIBGE e IEA

Extraîdo de Mendonça e Graham (1978)

OBS.: Taxas calculadas pela regressão da forma $X_{t}=a \cdot e^{b t}$

$a_{0 s}$ coeficientes estimados não diferem estatisticamente de zero. 
TABELA 2.6 - Taxas de crescimento da produtividade, por grupos de produtos e regiões

(\%) ao ario

1. Exportāveis - Nordeste

4,90

2. Exportāveis sem café - Nordeste

4,25

3. Domésticos - Nordeste

$-4,52$

4. Exportāveis - Centro-Sul

$0,00^{\mathrm{a}}$

5. Exportāveis sem café - Centro-Sul

$0,00^{\mathrm{a}}$

6. Domésticos - Centro-Sul

$0,00^{\mathrm{a}}$

7. Exportāveis - São Paulo $.72,59$

8. Exportáveis sem café - São Paulo

$0,00^{\mathrm{a}}$

9. Domésticos - São Paulo

8,02

10. Exportáveis - Brasil

$0,00^{\mathrm{a}}$

11. Domésticos - Brasil

$0,00^{\mathrm{a}}$

Fontes: FIBGE e IEA

Extraỉdo de Mendonça e Graham (1978)

OBS.: Ver Tabela 2.5

${ }^{a}$ Os coeficientes estimados não diferem estatisticamente do zero. 
Por outro 1ado, observamos, a partir da TABELA 2.7, que o crescimento da área total da agricultura foi mais intenso no perīodo 70 a: 75 do que no periodo anterior. No auge do processo de Modernização Conservadora hā uma grande incorporação de terras na fronteira agrīcola. Toda a política de incentivos fiscais, a partir do inīcio dos anos 70 , é o principal elemento dinamizador da ocupação destas āreas.

Estudos mais especifificos sobre a questão da ocupação da fronteira colocam que esta tem se dado com a utilizaçăo de tecnologia bastante sofisticada. Ou seja, mesmo a ocupação da fronteira faz uso da industrialização da agricultura. Diversos estudos, por outro lado, colocam que a ocupação da fronteira é uma forma arcaica de desenvolver a agricultura. Devemos compreender que para o processo de acumulação do capital o elemento fundamental è a busca de novos espaços para a sua valorização. E este processo pode se dar atravēs da ocupação da fronteira, com a elevação da produção, ou atravēs da intensificação da produção nas áreas jä ocupadas. Na medida em que os dois processos possibilitem uma maior subordinação da agricultura, eles são indiferentes ao capital.

Mas, na medida em que a Modernização Conservadora กล̃o acarretou grandes incrementos no rendimento por hectares, mas mesmo assim implementou uma política de grandesincentivos à industrialização, qual o seu verdadeiro sentido? A partir da TABELA $2.8^{1}$ podemos ter uma amostra do que tem sido a real consequência da recente modernização: uma grande elevação da rentabilidade por homem ocupado.

0 sentido desta anālise difere substantivamente da de HAYAMI-RUTTAN no aspecto de que estes pensam que o desenvolvimento tecnológico da agricultura, com o consequente aumento da produção e da produtividade,..."serā determinado, em grande parte pela dotação relativa de fatores". (in Contador-1975, pg. 10). Isto è, para estes autores a

${ }^{1}$ Apesar das informações da Tabela 2.8 possibilitarem uma comparação entre os 2 anos hă limitações: 0 valor da produção total não engloba alguns produtos como a banana e estoque de criações; e 0 pessoal ocupado e uma estimátiva da pesquisa UNICAMP-FINEP. 
tecnologia tem um papel especîfico de substituir o fator de produção (ter ra ou trabalho) que apresenta inelasticidade em sua oferta. Estas inelas ticidades fariam com que os preços dos fatores se elevassem, levando os agricultores a pressionar o governo para superar as limitações impostas pelas inelasticidades. A superação se daria atravēs das instituições go vernamentais de pesquisa e de assistência tēcnica, que, dada a pressão dos agricultores, gerariam e difundiriam tecnologia que aumentasse a elas ticidade da oferta dos fatores limitantes.

Assim sendo, para esses autores, a não elevação da prodụ tividade por hectare e a elevação da produtividade do trabalho indicariam que o fator terra tem grande elasticidade de oferta, enquanto o fator tra balho teria baixa elasticidade.

Mas parece bastante questionāvel este tipo de conclusão . pois, além de não ter havido inelasticidade de oferta de trabalho, houve uma grande expulsão de homens do campo. Isto ē, o grande crescimento da utilização de máquinas e o sentido da modernização de uma: forma geral , não ocorreram em função da pressão de preços relativos. E muito menos de correu da pressão dos agricultores sobre os örgãos oficiais de pesquisa e assistência técnica para a criação de tecnologia. Esta tecnologia veio em grande parte do exterior, na forma de pacotes, sendo apenas adaptadas aqui e transferidas para os agricultores de uma forma quase que autoritária. Portanto nos parece bastante difícil aceitar como explicação para 0 processo de modernização da agricultura brasileira o modelo de "inovações induzidas" "de Hayam e Ruttan. No nosso entender a modernização da agricưl tura como jā colocado voltou-se basicamente para a elevação da produtividade do trabalho.

Portanto a explicação da modernização atravēs da inelast cidade de oferta de fatores não condiz com a realidade. 0 verdadeiro sen tído da elevação da produtividade do trabalho no campo è que "viábiliza uma maior geração de trabalho excedente além de subordinar este trabalho, gerando tambēm no campo um espaço para o grande capital acumulado.

Neste sentido parece-nos bastante claro que o processo de industrialização da agricultura, atravēs de todos os mecanismos que o Es tado tem implementado, viabilizou um campo propỉcio à acumulação capitá 1ista. No processo de subordinar a agricultura, esta industrialização pos 
sibilitou uma produção com uma menor utilização da força de trabalho. Mas entendemos que no futuro, com o esgotamento da fronteira e com a necessidade que o capital tem de continuar a expandir seu espaço de valorização na agricultura, uma elevação do rendimento da terra far-se-ā necessāria.

TABELA 2.7 - Area de Lavoura e Area Total Ocupada para o Brasil 1950/ $60 / 70 / 75$ e Taxas de Crescimento Anuais

AREA DE LAVOURA

TAXA DE

MIL ha
CRESCIMENTO

ANUAL
- ĀREA TOTAL

TAXA DE

MIL ha

CRESCIMENTO

ANUAL

\begin{tabular}{lllll}
\hline 1950 & 19.095 & & 232.211 & \\
1960 & 28.712 & 4,16 & 249.862 & 0,74 \\
1970 & 33.984 & 1,70 & 294.145 & 1,64 \\
1975 & 38.909 & 2,74 & 323.896 & 1,95 \\
\hline
\end{tabular}

Fonte: CENSOS AGROPECUARIOS 1950, 1960, 1970 e 1975 
TABELA 2.8 - Rendimento por homem ocupado - Brasil - 1970 - 1975 Cr\$ 1.000 de 1977 (a)

1970 1975

Valor da produção total ${ }^{a}$ 305.044 .760 434.979 .700

Despesas correntes ${ }^{b}$

47.385 .221

61.343 .811

Valor da produção menos despesa

275.659 .540

353.635 .890

Total de pessoal ocupado (em equiva lente homem)

15.052 .775

17.325 .041

Rendimento por homem ocupado (em equivalente homem )

17,12 20,41

Taxa de crescimento do rendimento $3,6 \%$ a.a.

Taxa de crescimento do pessoal ocu pado $2,8 \%$ a.a.

a) Deflacionado pelo ĩndice de Preços Recebidos pela Agricultura (IPRA)

b) Total de despesas - salários - quota parte - empreitada - juros ban cários. deflacionado pelo Indice de Preços Pagos pela Agricultura (IPPA)

FONTE: CENSOS AGROPECUARIOS 1970 e 1975 UNICAMP/FINEP (1981) 


\subsubsection{Progresso Técnico por Estrato de Ārea}

A visão global do processo de utilização de técnicas modernas permite-nos apenas afirmar que a modernização ganhou uma dinâmica mais acentuada nos anos 70/75. Com a anālise que desenvolveremos neste item pretendemos destacar o tipo de estabelecimento, por estrato de ārea, que mais intensificou sua produção.

A partir da TABELA 2.9 podemos observar que nos menores estabelecimentos hā a utilização mais intensa de força humana, como forma exclusiva de força; contudo, apesar de decrecer em todos, foi nos maiores estabelecimentos que esta utilização mais decresceu. Por outro 1ado, no que se, refere à utilização de força animal, observamos que seu decréscimo se dá nas pequenas e médias propriedades, enquanto nas grandes hã um pequeno crescimento de sua utilização.

0 crescimento da participação de estabelecimentos que se utilizam de força mecânica foi maior entre os grandes, apesar de podermos perceber um crescimento apreciável em todos os estratos de ārea.

A TABELA 2.10 indica-nos inicialmente que as maiores participações em 1975 em termos de utilização de tecnologia moderna estão ligados aos grandes estabelecimentos. Isto se deve, como veremos mais adiante, à prōpria polîtica de crédito, entre outros fatores. A maior utilização de tratores, arados de tração mecânica, colhedeiras, defẹnsivos dão clara mostra do maior nīvel tecnológico dos grandes estabeleciinentos.

0 crescimento da utilização de tratores, arados de tração mecânica e adubos pode ser observado em todos os estratos. Entretanto, a utilização de tratores e arados de tração mecânica apresenta maior crescimento entre os grandes estabelecimentos.

Por outro 1ado, a utilização de adubos mais eresceu entre os pequenos (10-100) e médios (100 a 1.000) estabelecimentos. No nosso entender, o crescimento da utilização de adubos entre os pequenos estā ligado à polîtica do GERCA/I.B.C. para o café e de Crédito Rural que 
mui to o incentivou. Enquanto entre ós grandes estabelecimentos relativa mente poucos se utilizam de adubos, dadas as vastas āreas de pastagens nor malmente naturais.

Isto nos indica que apesar do progresso técnico ser predominante nos grandes estabelecimentos (mais de 1.000ha), entre os pequenos $(0$ a 100$)$ e médios $(100$ a 1.000) tambēm houve um progresso técnico bastante intensivo.

TABELA 2.9 - Porcentagem de estabelecimentos que usam a força humana, animal, mecānica e animal e mecânica-Brasil 1970 e 1975

\begin{tabular}{cccccccccc}
\hline $\begin{array}{c}\text { ESTRATOS } \\
\text { DE AREA }\end{array}$ & $\begin{array}{c}\text { APENAS FOR- } \\
\text { ÇA HUMANA }\end{array}$ & $\begin{array}{c}\text { FORÇA } \\
\text { ANIMAL } \\
(\mathrm{a})\end{array}$ & $\begin{array}{c}\text { FORCA } \\
\text { MECANICA } \\
(\mathrm{b})\end{array}$ & $\begin{array}{c}\text { FORÇA ANIMAL } \\
\text { E MECANICA } \\
(\mathrm{c})\end{array}$ \\
\hline \multicolumn{1}{c}{ ha } & 1970 & 1975 & 1970 & 1975 & 1970 & 1975 & 1970 & 1975 \\
\hline Menos 10 & 77,6 & 72,6 & 20,0 & 17,9 & 1,3 & 6,3 & 1,1 & 3,2 \\
10 a 100 & 51,7 & 45,3 & 39,6 & 36,0 & 2,6 & 9,4 & 6,1 & 9,4 \\
100 a 1.000 & 60,1 & 51,9 & 24,0 & 25,3 & 6,1 & 16,7 & 9,9 & 6,1 \\
1.000 a 10.000 & 56,8 & 44,0 & 14,7 & 18,8 & 13,3 & 31,7 & 15,1 & 5,5 \\
10.000 e mais & 45,1 & 32,9 & 7,6 & 10,3 & 31,7 & 54,1 & 15,6 & 2,7 \\
\hline \multirow{2}{*}{ TOTAL } & 65,8 & 60,1 & 27,9 & 25,4 & 2,3 & 8,6 & 3,9 & 5,8 \\
\hline
\end{tabular}

Fonte: CENSOS AGROPECUARIOS 1970 e 1975.

(a)Porcentagem de estabelecimentos que usam força humana e animal.

(b)Porcentagem de estabelecimentos que usam força humana e mecânica.

(c)Porcentagem de estabelecimentos que usam força humana, animal e mecänica. 
TABELA 2.10 - Porcentagem de estabelecimentos que usam: tratores, arados de tração animal, arados de tração mecância, colhedeiras, adubos e defensivos - Brasil - 1970 - 1975 (\%).

\begin{tabular}{|c|c|c|c|c|c|c|}
\hline \multirow{3}{*}{$\begin{array}{l}\text { ESTRATOS } \\
\text { DE AREA } \\
\text { Ha }\end{array}$} & \multirow{2}{*}{\multicolumn{2}{|c|}{ TRATORES }} & \multicolumn{4}{|c|}{ ARADOS } \\
\hline & & & \multicolumn{2}{|c|}{ TRAÇÃO ANIMAL } & \multicolumn{2}{|c|}{ TRAÇÃO MECĀNICA } \\
\hline & 1970 & 1975 & 1970 & 1975 & 1970 & 1975 . \\
\hline Menos 10 & 0,4 & 0,6 & 13,1 & 12,9 & 0,3 & 0,4 \\
\hline 10 a 100 & 3,0 & 6,1 & 36,0 & 37,6 & 2,5 & 5,5 \\
\hline 100 a 1.000 & 9,6 & 15,7 & 25,0 & 24,3 & 8,4 & 13,9 \\
\hline 1.000 a 10.000 & 22,8 & 35,0 & 20,5 & 16,6 & 19,3 & 29,7 \\
\hline 10.000 e mais & 44,5 & 57,5 & 10,3 & 6,3 & 26,4 & 34,7 \\
\hline TOTAL & 2,4 & 4,3 & 23,1 & 23,3 & 2,0 & 3,8 \\
\hline
\end{tabular}

\begin{tabular}{ccccccc}
\hline $\begin{array}{c}\text { ESTRATOS } \\
\text { DE AREA }\end{array}$ & \multicolumn{2}{l}{ COLHEDEIRAS } & \multicolumn{2}{c}{ ADUBOS } & \multicolumn{2}{c}{ DEFENSIVOS } \\
\hline \multicolumn{1}{c}{ Ha } & 1970 & 1975 & 1970 & 1975 & 1970 & 1975 \\
\hline Menos 10 & 0,3 & 0,1 & 11,3 & 13,9 & n.d. & 34,2 \\
10 a 100 & 2,4 & 1,8 & 20,5 & 32,3 & n.d. & 67,8 \\
100 a 1.000 & 3,9 & 5,3 & 16,8 & 28,0 & n.d. & 74,7 \\
1.000 a 10.000 & 6,5 & 9,4 & 18,0 & 27,6 & n.d. & 87,6 \\
10.000 e ma is & 7,4 & 9,1 & 8,9 & 18,7 & n.d. & 87,7 \\
\hline TOTAL & 1,5 & 1,3 & 15,4 & 22,3 & n.d. & 51,0 \\
\hline
\end{tabular}

Fonte: CENSOS AGROPECUARIOS 1970 e 1975. 
A partir da TABELA 2.10 podemos também concluir que a utilização dos outros insumos modernos tem uma participação progressivamente maior à medida que crescem os estabelecimentos, exceto no caso dos adubos onde as maiores utilizações dão-se ao nīvel dos estabelecimentos entre 10 e 100ha.e $100-1.000$ ha.

Ainda quanto à utilização de técnicas modernas observamos, na TABELA 2.11, que a utilização de irrigação apresentou um crescimento bastante homogēneo entre os mëdios e grandes estabelecimentos, mas a sua utilização ainda ē bastante restrita, observando-se tambēm um crescimento pequeno nas pequenas propriedades.

No referente à utilização de mão-de-obra podemos notar, a partir da TABELA 2.11, que especificamente nos estabelecimentos de atē 1.000ha houve um crescimento da utilização de trabalho temporārio. Isto significa, no nosso entender, que com a modernização, estas propriedades, ao não se utilizarem tão intensamente da mecanização no processo produtivo, viram-se na obrigação de contratar mão-de-obra temporāria. Por outro 1ado, ocorreu nas propriedades de mais de 100ha um crescimento acentuado de trabalhadores permanentes, o que pode ser consequência da pecuarização observada no perỉodo, ou mesmo da necessidade de trabalho permanente para os serviços com máquinas. Cabe ressaltar que os dados referentes a utilização de mão-de-obra do Censo são problemāticos ${ }^{1}$, e que, segundo pesquisa desenvolvida pela UNICAMP/FINEP (1981), no referente a emprego no setor agrīcola, o grande crescimento que se deu é da empreitada coletiva, observāvel tanto entre pequenos e grandes estabelecimentos, basicamente nas regiões mais modernizadas.

A TABELA 2.12 mostra-nos que o crescimento ocorrido no trabalho contratado por empreiteiros (empreitada coletiva) foi bastante grande, da ordem de $3,1 \%$ ao ano. Este dado, em equivalentes - homem ${ }^{2}$ (força de trabalho de um homem adulto ocupado em média 300 dias por ano),

\footnotetext{
¿Vide maiores explicações no item 2.3.7.

¿2para maiopes dọtalhes vide UNICAMP/FINEP (1981) pāgs. 278 a 284.
} 
TABELA 2.11 Porcentagem de estabelecimentos que se utilizam de irrigação, trabalho temporärio e trabalho permanente - Brasil, $1970-1975(\%)$

\begin{tabular}{lcccccc}
\hline $\begin{array}{c}\text { ESTRATOS } \\
\text { DE AREA }\end{array}$ & IRRIGAÇAO & $\begin{array}{c}\text { TRABALH0 } \\
\text { TEMPORARI0 }\end{array}$ & \multicolumn{2}{c}{$\begin{array}{c}\text { TRABALHO } \\
\text { PERMANENTE }\end{array}$} \\
\hline Ha & 1970 & 1975 & 1970 & 1975 & 1970 & 1975 \\
\hline-10 & 1,6 & 2,1 & 3,9 & 4,0 & 1,8 & 1,5 \\
10 a 100 & 2,6 & 3,8 & 9,6 & 10,4 & 7,9 & 8,6 \\
100 a 1.000 & 2,9 & 4,2 & 18,8 & 19,2 & 31,4 & 35,6 \\
1.000 a 10.000 & 3,9 & 5,1 & 27,2 & 24,6 & 64,4 & 69,1 \\
10.000 e mais & 2,1 & 3,3 & 29,7 & 23,5 & 79,6 & 83,6 \\
Brasi1 & 2,1 & 3,0 & 7,6 & 8,0 & 7,2 & 7,8 \\
\hline
\end{tabular}

Fonte: CENSOS AGROPECUĀRIOS 1970 e 1975

TABELA 2.12 - Mëdia anual de força de trabalho em equivalentes-homem tratado por empreiteiros - Brasil - 1970 - 1975.

1970

$\cdot 1975$

1.146 .505
TAXA DE CRESCIMEN-

TO ANUAL $(\%)$

984.826

Fonte: UNICAMP/FINEP (1981) 
mostra o crescimento da utilização do trabalhador contratado coletivamente (böia-fria, etc.) na agricultura brasileira.

Mas, para uma compreensão das alteraçõès da utilização da força de trabalho, em cada um dos estratos de ärea, faz-se necessārio uma anālise que englobe o número de trabalhadores. A TABELA 2.13 demonstra-nos uma vez mais que os maiores crescimentos da participação do número de trabalhadores permanentes deram-se nas grande propriedades. Por outro lado, o maior crescimento em termos dos responsāveis e memibros da famīilia deu-se nas propriedades de até 10ha, mostrando que não è geral 0 processo de proletarização dos pequenos produtores, pois seu nümero chega inclusive a aumentar.

Outras questões no referente à utilização da mão-de-obra podem ser analisadas a partir dos mesmos dados, se algumas transformações forem feitas. A TABELA 2.14 dá-nos inicialmente uma idéia de que a média de responsāveis e membros não remunerados da famīlia por estabelecimento é rerativamente estāvel em todos os estratos de ārea. Porēm, o número de responsáveis e membros não remunerados por mil hectares decresce de forma acentuada dos menores para os maiores estratos. Quanto a trabalhadores permanentes nota-se a elevação de sua utilização pelos estabelecimentos nos estratos de maiores áreas, tanto por estabelecimento quanto por área, que, como jā colocamos anteriormente, indica a necessidade imposta pelas transformações da agricultura brasileira de manter este tipo de trabalhador. Por outro lado, observamos a elevação do número de trabalhadores temporários apenas nas pequenas e médias propriedades, demonstrando mais uma vez que, dada a tecnologia utilizada, os pequenos e médios tem de se utilizar de trabalhadores temporārios para sua produção. Deve-se ter em mente que estes trabalhadores temporārios são muitas vezes vizinhos, ou pequenos proprietários próximos que executam tarefas para outros pequenos proprietários. 


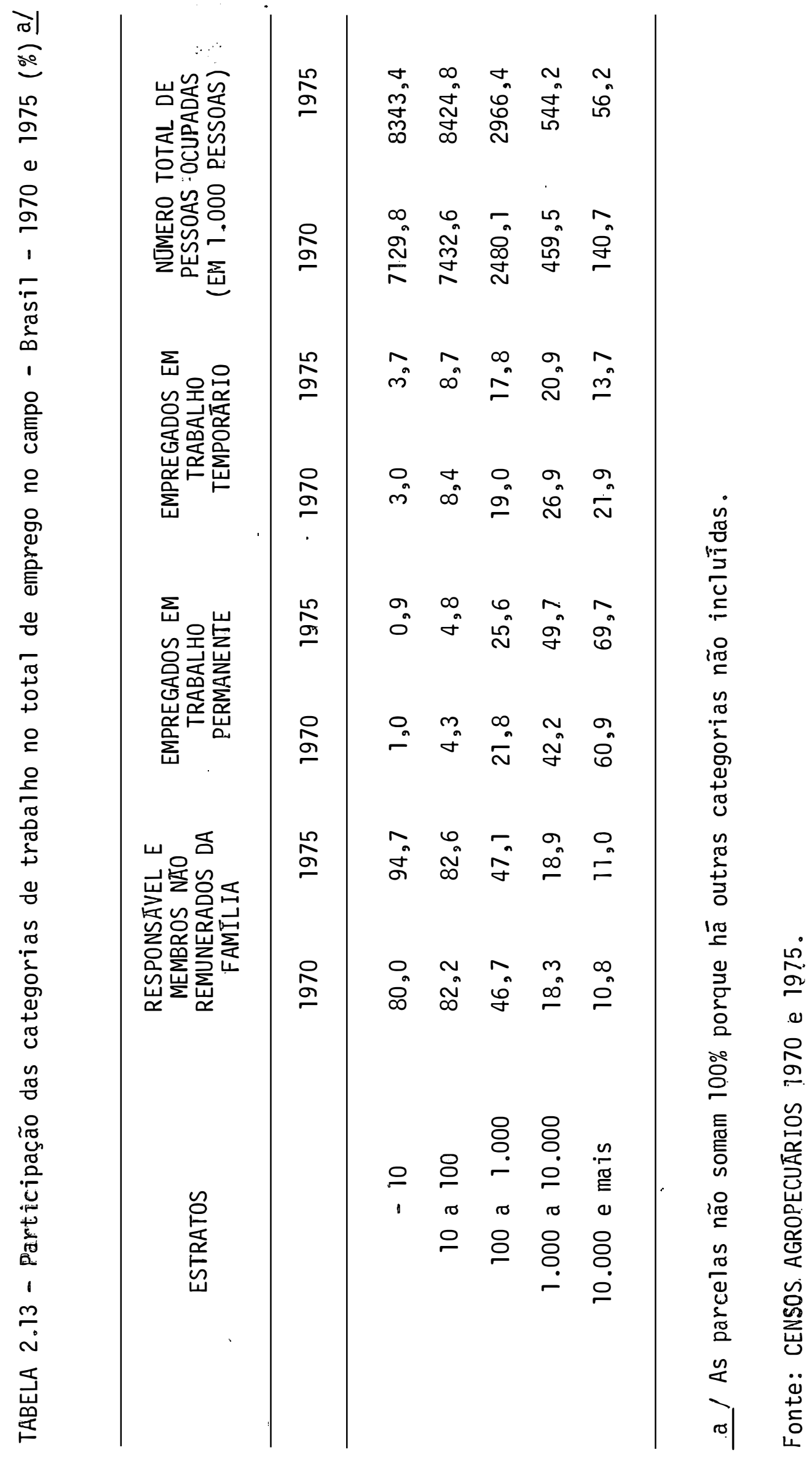


1。

밈

$\frac{9}{8}$

ᄒ̀

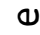

高

호

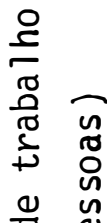

จ

:

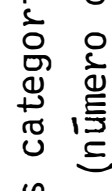

年

ง ลั

$\circ 0$

s

ฉ

다.

总:

竞

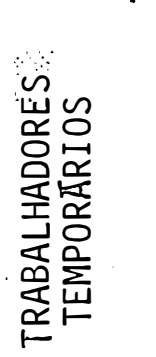

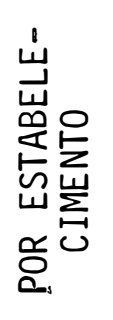

.

م

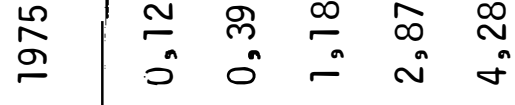

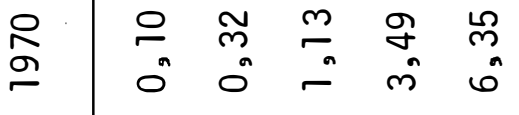

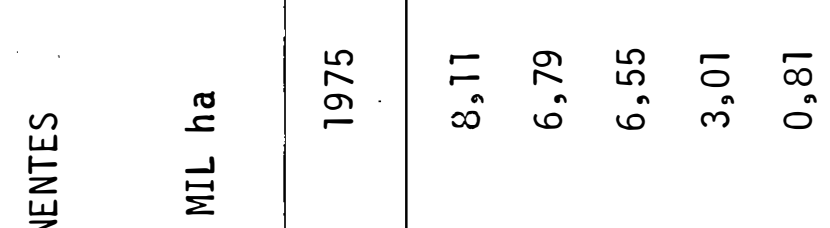

옹

㟧

$\frac{}{2}$

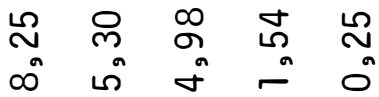

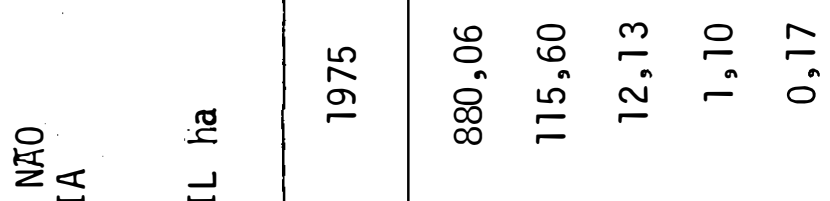

豆

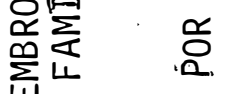

㠇造

w

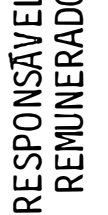

岂

옹 $\stackrel{\stackrel{2}{2}}{\frac{1}{2}}$

(1)

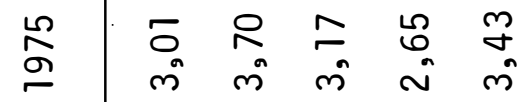

일

I

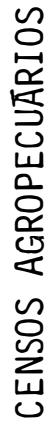

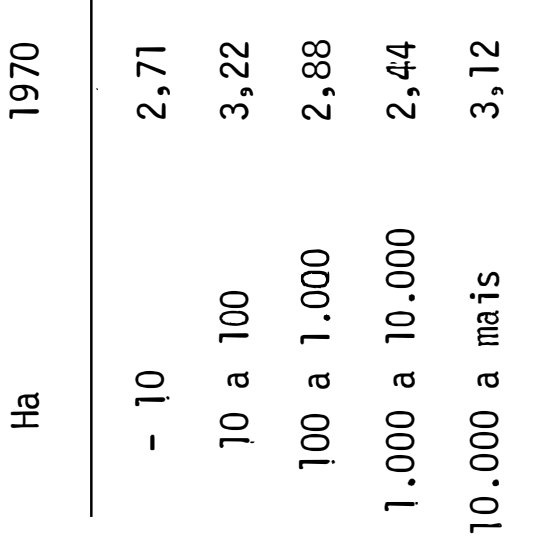




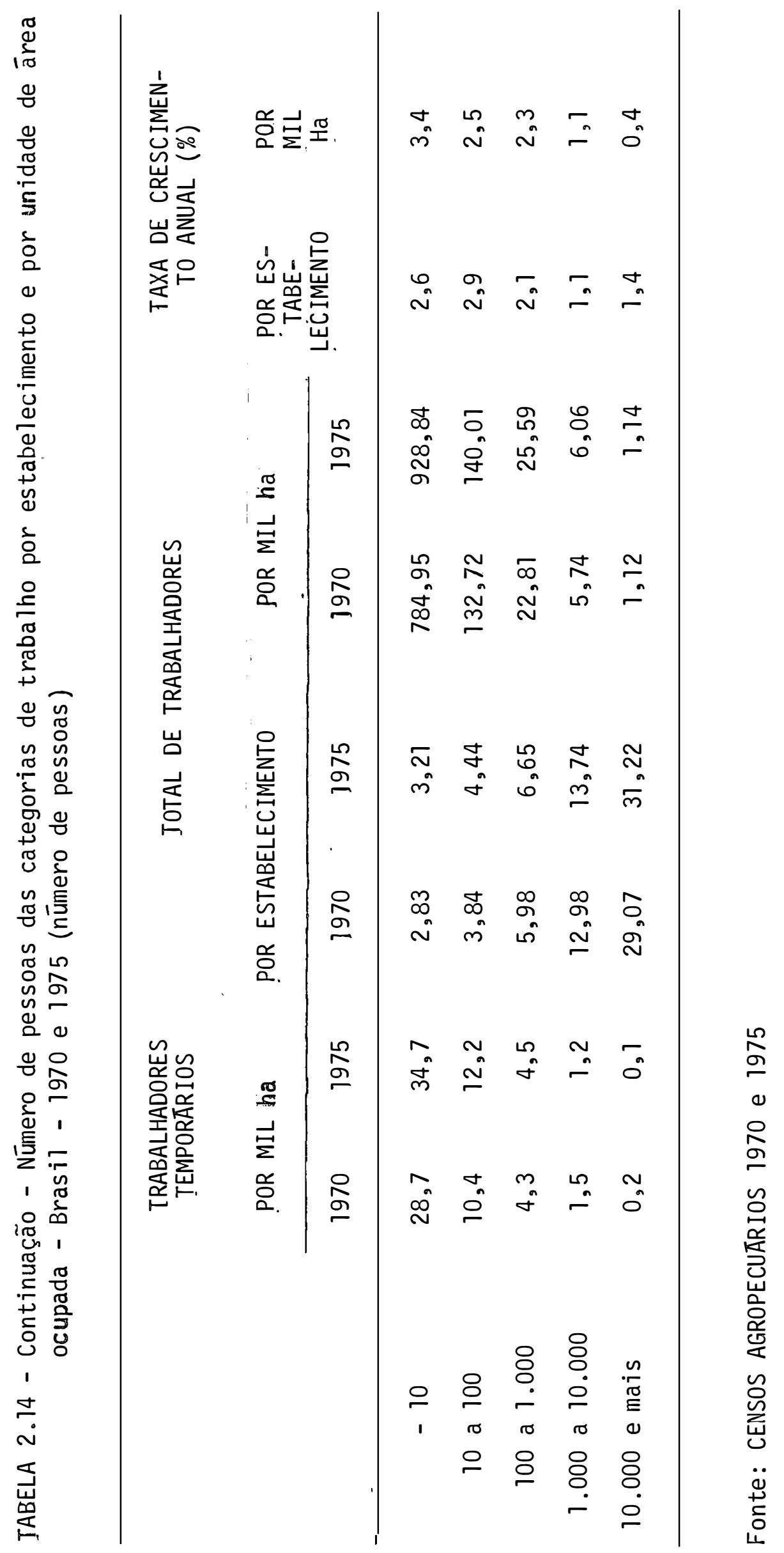


Mas hā um outro aspecto que condiciona a utilização de mão-de-obra: ē o tipo de exploração agrĩcola. Como se observa na TABELA 2.15, a utilização de terras para lavouras temporārias tem uma participação decrescente dos menores para os maiores estabelecimentos. Jā as lavouras permanentes ocupam relativamente pequena ārea dos diversos estratos, aparecendo com maior intensidade nos microestabelecimentos. Enquanto a ārea com pastagens apresenta um significativo aumento dos menores para os maiores estabelecimentos atingindo maior participação nos estabelecimentos entre 1.000 e 10.000 ha.

As variações mais significativas entre 1970 e 1975 quanto à utilização de terras são: uma pequena queda na participação da area de lavouras permanentes entre os microestabelecimentos e as quedas na participação das āreas de pastagens nos estratos acima de 1.000ha, não afetando profundamente a panorama geral da produção agropecuāria.

Podemos inferir que as criações tem uma grande participação entre os grandes estabelecimentos. Em decorréncia das caracterīsticas especĩficas da exploração de criações, é mais frequente a utilização de mão-de-obra permanente para este setor. Enquanto para as lavouras temporārias, com maior participação entre os estabelecimentos atē 100ha, è a mão-de-obra familiar que aparece com maior frequência, excetuando-se, é claro, a cana-de-açūcar, onde inclusive os pequenos estabelecimentos se utilizam de bōias-frias.

Na lavoura permanente, a maior participação de pequenos estabelecimentos levou à utilização de mão-de-obra familiar e, ultimamente também, o trabalhador volante.

Jā vimos que o tipo de exploração condịciona a utilização de mão-de-obra. Como exemplo, as criações utilizam praticamente apenas trabalhadores permanentes. Nas outras explorações, entretanto, a determinação maior se dā pelo tamanho de estabelecimento e as prōprias condições técnicas de produção. 0 caso do cafēé bastante ilustrativo, onde nos pequenos estabelecimentos basicamente hă a utilização de mão-de-obra familiar, enquanto nos maiores estabelecimentos, onde hā um mercado de trabalhadores volantes, estes são utilizados com grande frequência. 
TABELA 2.15 - Utilização de Terras no Brasil - 1970 e 1975 (\%)

\begin{tabular}{|c|c|c|c|c|c|}
\hline \multicolumn{2}{|c|}{$\begin{array}{l}\text { LAVOURA } \\
\text { TEMPORARIA }\end{array}$} & \multicolumn{2}{|c|}{$\begin{array}{l}\text { LAVOURA } \\
\text { PERMANENTE }\end{array}$} & \multicolumn{2}{|c|}{ PASTAGENS } \\
\hline 1970 & 1975 & 1970 & 1975 & 1970 & 1975 \\
\hline 53,9 & 54,1 & 12,0 & 10,8 & 15,1 & 15,8 \\
\hline 20,2 & 21,3 & 6,0 & 6,0 & 37,6 & 38,4 \\
\hline 6.4 & 8,6 & 2,4 & 2,4 & 55,3 & 55,8 \\
\hline 2,4 & 3,9 & 0,8 & 0,8 & 62,9 & 61,7 \\
\hline 0,4 & 0,8 & 0,2 & 0,4 & 54,3 & 42,9 \\
\hline
\end{tabular}

Fonte: FIBGE - CENSOS AGROPECUÄRIOS DE 1970 e 1975.

Devemos salientar que os efeitos do progresso téđnico sobre os diversos estratos de estabelecimentos são bastante distintos. Enquanto o grande ao se modernizar, geralmente viabiliza uma produção mais rentāvel, obtendo maiores lucros, o médio produtor ao se tecnificar pode estar obtendo maiores lucros, ou apenas viabilizando sua manutenção.

Parte dos pequenos produtores, dada a escala de sua produção e dada sua inserção no processo produtivo, subordinado ao cąpital comercial, ou às agroindūstrias e "Cooperativas Capitalistas", ou ainda ao capital financeiro, se viu na obrigação de se tecnificar.

A tecnificação e a crescente subordinação fizeram com que o papel da pequena produção mudasse significativamente nos anos recentes.

Como coloca GRAZIANO DA SILVA (1980 b), a pequena produção perde importância como produtora de genêros alimentīcios ( atravēs da oferta de excedentes) e passa a produzir de acordo com as neces cidades do mercado com o objetivo explîcito de comercialização 
Is to è decorrência tanto do processo de crescente subordinação desta pequena produção, quanto da tecnificação que dela decorre. Mas esta tecnificação de pequena produção, normalmente não cria condições para o surgimento de grande nümero de "farmers"., nos moldes da agricultura norteamericana, mesmo porque não viabiliza uma elevação nos rendimentos dos pequenos produtores, pois apenas os torna mais subordinados tanto à jusante quanto à montante do processo produtivo.

Portanto, na maior parte das vezes, tambēm não significa um processo de capitalização da pequena produção, sendo apenas um processo de tecnificação que torna a pequena produção altamente subordinada ao grande capital.

\subsubsection{Progresso Técnico por Estado}

A partir da visão de que houve uma diferenciação entre estabelecimentos quanto ao seu progresso técnico, faremos nes te item um estudo acerca de como este processo se deu em diversos Estados ${ }^{1}$. Analisa remos aqui, de uma forma comparativa, tanto, a intensidade de uso de ino vações técnicas, quanto seu incremento durante o quinquēnio 1970/1975.

A TABELA 2.16 deixa clàro que o processo de transformação na utilização dos diversos tipos de força ē extremamente heterogêneo. Há Estados, como São Paulo, que apresentam o maior crescimento do número de estabelecimentos que se utilizam de força mecânica e um decréscimo na utilização de força animal e humana. Outros, como Santa Catarina, alēm do crescimento da utilização de força mecânica, apresentam maior crescimento de utilização de força anima $]_{\text {. }}$ Hā ainda Estados, como Alagoas, onde houve uma diminuição mui to grande na utilização de força humana e um crescimento da força animal e mecãnica.

${ }^{1} A$ anālise restringe-se a 17 Estados (Maranhão, Cearā, Rio Grande do Norte, Paraíba, Pernambuco, Alagoas, Sergipe, Bahia, Minas Gerais, Espïrito Santo, Rio de Janeiro, São Paulo, Paranā, Santa Catarina, Rio Grande do Sul, Mato Grosso e Goiās), dado que o restante do trabalho, em função dos dados disponĩveis, trata dos mesmos Estados. 
TABELA 2.16 - Porcentagem do total de estabelecimentos que se utilizam dos diversos tipos de força - 17 Estados - 1970 è 1975.

\begin{tabular}{|c|c|c|c|c|c|c|c|c|}
\hline & \multicolumn{2}{|c|}{ SŌ HUMANA } & \multicolumn{2}{|c|}{ ANIMAL } & \multicolumn{2}{|c|}{ MECĀNICA } & \multicolumn{2}{|c|}{$\begin{array}{l}\text { ANIMAL E } \\
\text { MECÂNICA }\end{array}$} \\
\hline & 1970 & 1975 & 1970 & 1975 & 1970 & 1975 & 1970 & 1975 \\
\hline MA & 99,7 & 98,9 & 0,2 & 0,2 & - & 0,9 & - & - \\
\hline CE & 90,2 & 75,5 & 8,2 & 12,9 & 0,6 & 10,5 & 0,4 & 1,2 \\
\hline RN & 72,7 & 60,9 & 26,5 & 28,3 & 0,2 & 9,1 & 0,4 & 1,6 \\
\hline PB & 85,8 & 71,0 & 13,5 & 19,7 & 0,3 & 7,9 & 0,4 & 1,4 \\
\hline PE & 90,1 & 76,8 & 8,7 & 18,1 & 0,8 & 4,6 & 0,4 & 0,5 \\
\hline$A L$ & 77,6 & 60,7 & 21,1 & 34,5 & 0,7 & 4,3 & 0,6 & 0,4 \\
\hline SE & 96,4 & 88,7 & 2,7 & 5,3 & 0,6 & 5,8 & 0,1 & 0,2 \\
\hline$B A$ & 86,8 & 79,4 & 11,1 & 12,7 & 1,1 & 6,6 & 0,9 & 1,2 \\
\hline$M G$ & 57,6 & 48,3 & 35,6 & 36,3 & 1,9 & 9,4 & 4,9 & 5,9 \\
\hline ES & 84,9 & 74,2 & 11,4 & 14,5 & 2,5 & 9,7 & 1,2 & 1,6 \\
\hline RJ & 67,1 & 62,4 & 24,3 & 21,8 & 5,7 & 13,5 & 3,0 & 2,4 \\
\hline$S P$ & 24,9 & 21,0 & 49,5 & 45,6 & 9,4 & 21,9 & 16,2 & 11,4 \\
\hline PR & 46,2 & 32,0 & 45,0 & 42,5 & 2,9 & 14,8 & 5,9 & 10,7 \\
\hline SC & 24,3 & 19,7 & 64,9 & 69,8 & 1,1 & 4,6 & 9,7 & 5,9 \\
\hline RS & 11,9 & 7,4 & 76,8 & 55,6 & 3,4 & 8,6 & 7,9 & 28,4 \\
\hline MT & 73,2 & 66,1 & 20,6 & 16,0 & 4,3 & 15,0 & 1,9 & 2,9 \\
\hline GO & 72,3 & 61,9 & 13,8 & 10,9 & 7,3 & 19,9 & 6,6 & 7,2 \\
\hline
\end{tabular}

Fonte: CENSOS AGROPECUĀRIOS DE 1970 E 1975 
Cabe ressaltar que o Progresso Técnico se faz presente de diferentes'formas nas diferentes regiões. Para o Nordeste, por exemplo, uma maior utilização de força animal significa uma elevação da produtividade. Por outro lado, na maioria dos estados do Sul, Sudeste e Centro-0este há quedas na utilização de força animal e um crescimento da força mecânica indicando que o Progresso Técnico nestes estados atinge um nível tecnológico mais elevado.

Para 'o Nordeste observamos que Alagoas, além de ter 0 maior decréscímo no nümero de estabelecimentos que se utilizam de força humana, teve o maior crescimento na utilização de força animal. Este não deixa de ser um tipo de progresso técnico da agricultura. Por outro lado, observamos os maiores valores para a proporção das propriedades que se utilizam de força mecânica nos Estados do Cearā e Rio Grande do Norte. Quanto aos indica'dores de progresso técnico apresentados na TABELA 2.17, observamos uma baixa intensidade de utilização por parte do Nordeste de uma forma geral, inclusive de arados de tração ani mal. Os maiores crescimentos em termos de utilização de tratores, ara dos de tração mecânica e adubos são observāveis nos estados de Alagoas, Sergipe e Bahia.

Em contrapartida, para a região Sudeste o quadro é bastante distinto, dado que a utilização de técnicas modernas è mais difundida que nas demais regiões. Excetuando-se Espīrito Santo e o Rio de Janeiro, a utilização de força humana, alēm de sofrer um grande decréscimo, é relativamente pequena como forma exclusiva de força nos estabelecimentos, como observamos na TABELA 2.16. Podemos observar, na TABELA 2.17 a diferença entre a modernização da agricultura do Espīrito Santo e dos demais Estados; no Espīrito Santo hā um incremento de utilização de força animal, de arados de tração animal e a utilização de força humana é grande, enquanto nos demais Estados se dā a mecanização com arados, tratores e força mecânica. Devemos salientar que a partir das TABELAS 2.16 e 2.17 observamos um grande crescimento da mecanização de todos os tipos em São Paulo para o período 1970/75, mesmo sendo este - Estado mais mecanizado no Brasil. 
TABELA 2.17 - Nümero de máquinas e instrumentos por mị hectares de lavouras; porcentagem de estabelecimentos que se utilizam de adubos (quîmicos e orgânicos) - 17 Estados - 1970 e 1975.

\begin{tabular}{|c|c|c|c|c|c|c|c|c|}
\hline & \multicolumn{4}{|c|}{ ARADOS } & \multirow{2}{*}{\multicolumn{2}{|c|}{ TRATORES }} & \multirow{2}{*}{\multicolumn{2}{|c|}{ ADUBOS }} \\
\hline & \multicolumn{2}{|c|}{$\begin{array}{l}\text { TRAÇAO } \\
\text { ANIMAL }\end{array}$} & \multicolumn{2}{|c|}{$\begin{array}{l}\text { TRACAOO } \\
\text { MECANICA }\end{array}$} & & & & \\
\hline & 1970 & 1975 & 1970 & 1975 & 1970 & 1975 & 1970 & 1975 \\
\hline MA & 0,1 & 0,1 & 0,1 & 0.1 & 0,2 & 0,3 & 0,3 & 0,3 \\
\hline CE & $8,7$. & 10,8 & 0,5 & 0,4 & 0,6 & 0,6 & 7,3 & 5,7 \\
\hline RN & 22,8 & 1,3 & 0,6 & 0,8 & 0,7 & 1,4 & 9,8 & 9,6 \\
\hline PB & 6,0 & 43,1 & 0,6 & 0,9 & 0,7 & 1,2 & 4,0 & 4,7 \\
\hline$P E$ & 14,9 & 22,5 & 0,8 & 1,3 & 1,0 & 1,5 & 6,3 & 8,6 \\
\hline $\mathrm{AL}$ & 26,0 & 27,0 & 1,4 & 2,1 & 1,7 & 2,9 & 7,0 & 12,1 \\
\hline SE & 11,5 & 15,4 & 1,5 & 2,6 & 2,1 & 4,3 & 27,2 & 28,9 \\
\hline BA & 16,4 & 19,1 & 0,6 & 1,1 & 0,8 & 1,5 & 9,9 & 13,2 \\
\hline$M G$ & 40,8 & 37,7 & 2,9 & 5,3 & 2,9 & 5,4 & 30,5 & 39,2 \\
\hline ES & 9,8 & 10,0 & 1,3 & 2,1 & 1,6 & 2,8 & 13,0 & 23,9 \\
\hline RJ & 22,7 & 20,5 & 5,3 & 7,0 & 6,3 & 9,1 & 23,7 & 26,5 \\
\hline $\mathrm{SP}$ & 70,1 & 49,9 & 14,9 & 21,3 & 14,2 & 19,2 & 49,5 & 62,0 \\
\hline PR & 60,0 & 49,5 & 4,0 & 10,2 & 3,9 & 9,0 & 15,1 & 27,6 \\
\hline SC & 31,3 & 103,3 & 3,6 & 8,1 & 4,5 & 9,0 & 33,4 & 42,1 \\
\hline RS & 121,5 & 92,8 & 7,5 & 13,0 & 8,0 & 12,3 & 54,5 & 58,5 \\
\hline MT & 38,3 & 16,4 & 4,9 & 7,4 & 5,8 & 8,1 & 1,4 & 5,7 \\
\hline GO & 14,7 & 10,3 & 3,6 & 5,5 & 3,5 & 5,1 & 5,6 & 19,7 \\
\hline
\end{tabular}


Na região Sul observamos, a partir das mesmas TABELAS, um processo de modernização mais acentuado que o das demais regiões. Apesar de no Paranā a utilização de técnicas modernas ter uma dinâmica muito mais acentuada (é o Estado que tem.o maior crescimento de instrumentos mecānicos por hectares), os demais Estados tambēm apresentam um processo de tecnificação bastante intenso durante o perīodo.

Na região Centro-Oeste a utilização de modernos instrumentos na agricultura ainda é bastante pequena comparado com o Sul e o Sudeste, apesar de apresentar crescimento durante o quinquênio 70/75.

Um outro aspecto marcante das transformações no campo $\overline{\mathrm{e}}$ a crescente monetização das relações. Uma das formas de expressão desta monetização è a elevação das despesas que os estabelecimentos efetuam durante 0 ano.

$\mathrm{Na}$ medida em que as despesas em geral se elevam, percebemos uma maior integração e dependência do setor em relação ao processo de produção em geral. Neste sentido a TABELA 2.18 apresenta as variações entre 1970 e 1975 das principais despesas por hectare.

0 maior crescimento verificado foi nas despesas com as lavouras (adubos, sementes, mudas e defensivos) na maior parte dos Estados. Este crescimento foi maior nos Estados do Centro-Oeste e a seguir nos do Sul e do Sudeste. Isto parece bastante condizente com o tipo de desenvolvimento que se verificou nestas regiões, caracterizado por um crescimento na utilização de insumos e de técnicas modernas e uma maior mercantilização da produção.

As despesas totais também sofreram um crescimento bastante acentuado, mas seu maior crescimento foi observado nos Estados do Sul e vindo logo a seguir a região Centro-Oeste. Dado que o processo de introdução de técnicas modernas foi mais intenso nestas regiões, é exatamente nestes Estados que as despesas sofreram um crescimento maior. 
TABELA 2.18 - Variações dos valores reais de despesas por hectare, " 17 Estados, 1970 e 1975 (a)

\begin{tabular}{|c|c|c|c|c|}
\hline & \multicolumn{2}{|c|}{$\begin{array}{cl}\text { CRESCIMENTO } & \text { DAS DESPESAS } \\
70 & -75\end{array}$} & \multicolumn{2}{|c|}{$\frac{\text { DESPESA } 1975}{\text { (Cr } \$ \text { de } 77 / \text { ha })}$} \\
\hline & TOTAL (b) & LAVOURA (c) & TOTAL (b) & LAVOURA (c) \\
\hline MA & 100,0 & 73,0 & 299,75 & 33,83 \\
\hline CE & 57,3 & 0,0 & 362,90 & 34,41 \\
\hline RN & 91,9 & 90,5 & 373,52 & 53,15 \\
\hline PB & $100^{\circ}, 0$ & 62,9 & 484,64 & 76,59 \\
\hline $\mathrm{PE}$ & 53,3 & 116,5 & 924,26 & 342,80 \\
\hline AL & 86,9 & 73,3 & $1.663,30$ & $657 ; 57$ \\
\hline SE & 45,7 & 36,9 & 479,31 & 398,58 \\
\hline BA & 69,0 & 89,8 & 460,24 & 156,25 \\
\hline$M G$ & 109,6 & 180,6 & 489,70 & 595,89 \\
\hline ES & 57,0 & 230,2 & 697,74 & 314,65 \\
\hline RJ & 71,7 & 100,2 & $1.382,29$ & 494,24 \\
\hline$S P$ & 98,2 & 97,9 & $1.988,15$ & $1.486,74$ \\
\hline PR & 142,6 & 193,8 & $1.914,77$ & 884,15 \\
\hline SC & 178,3 & 248,3 & $1.155,22$ & 503,23 \\
\hline RS & 160,7 & 174,1 & $1.076,21$ & $1.183,30$ \\
\hline MT & 189,4 & 242,2 & 188,55 & 554,82 \\
\hline GO & 115,3 & 255,8 & 229,06 & 375,50 \\
\hline
\end{tabular}

(a) Deflacionado pelo indice 2 da F.G.V.

(b) Total de despesas efetuadas pelos estabelecimentos sobre a ärea total de pastagens e lavouras em ha.

(c) E a soma de despesas com adubos e corretivos, sementes e mudas, inseticidas e fungicidas sobre o número total de hectares com lavouras.

Fonte: CENSOS AGROPECUARIOS - 1970 e 1975. 
No que se refere a pessoal ocupado observamos, na TABELA 2.19, que nos Estados do Sudeste e no Paranā houve decréscimos, ou pequenos acrēscimos, no número total de pessoas ocupadas por ārea, indicando que o processo de modernização que ocorreu entre 1970 e 1975 elevou a produtividade por homem empregado nestas regiões. Nas demais regiões, muitas vezes o processo de modernização foi acompanhado por um crescimento na utilização de mão-de-obra.

Em termos dos responsāveis e membros não remunerados da famīila notamos, a partir da TABELA 2.19, que a maior utilização deu-se no Nordeste e no Sul, enquanto que a importāncia relativa dos trabalhadores permanentes cresceu mais na região Centro-0este e na região Sudeste. Isto reafirma a idéia de que no processo de modernização a necessidade de trabalhadores permanentes existe, ao menos nesta fase pela qual o Brasil passou.

A necessidade de trabalhadores permanentes deve estar ligada, tanto à ocupação de novas āreas, onde não haja um mercado de trabalho volante quanto à utilização crescente. de maquuinas que demandam trabalhadores permanentes para sua operação.

Ao observarmos mais atentamente os Estados do Nordeste, notamos que há pequenas quedas e aumentos em todos os estados no que se refere aos responsāveis e membros da famīlia, mas sua utilização é bastante grande. Somente trēs estados apresentam um crescimento na participação dos trabalhadores permanentes (CE, AL e BA), sendo que a participação desta categoria mais cresceu no estado de Alagoas, deixando claro uma vez mais a especificidade deste estado no que tange ao seu desenvolvimento.

Jā no Sudeste observanios uma estabilidade no nūmero de pessoas ocupadas, exceto em São Paulo, onde hā uma queda. Isto pode ser explicado pelo fim da fronteira agrĩcola desta região e também pela crescente utilização de técnicas modernas que elevam a produtividade dos trabalhadores. Quanto aos trabalhadores permanentes, observamos que houve aumento de sua participação em todos os estados. No que concerne a responsāveis e membros não remunerados, alēm de um acentuado aumento no Espirito santo @ uma queda em São Paulo, nos demais estados esta 
TABELA 2.19 - Porcentagem do total de pessoal ocupado e número total do pessoas por mil hectares - Algumas categorias - 17 Estados

$\begin{array}{cc}\text { RESPONSAVEL } & \text { HO DE PESSOAS } \\ \text { E MEMBROS NAOO } & \text { TRABALHADORES } \\ \text { REMUNERADOS } & \text { PERMANENTES OCUPADAS POR MIL } \\ \text { REMUNE } & \mathrm{Ha}\end{array}$

\begin{tabular}{llllll}
\hline 1.970 & 1975 & 1970 & 1.975 & 1970 & 1.975
\end{tabular}

TAXAS DE

CRESCIMEN-

TO ANUAL

$(\%)$

$\begin{array}{crrrrrrr}\begin{array}{c}\text { Nordeste } \\ \text { MA }\end{array} & 94,1 & 92,6 & 0,1 & 0,1 & 109,6 & 120,4 & 1,8 \\ \text { CE } & 72,6 & 81,3 & 2,3 & 3,7 & 84,4 & 90,9 & 1,5 \\ \text { RN } & 73,5 & 77,0 & 4,1 & 3,9 & 67,3 & 87,4 & 5,3 \\ \text { PB } & 79,6 & 82,9 & 4,2 & 3,4 & 127,6 & 168,8 & 5,8 \\ \text { PE } & 81,9 & 85,9 & 7,2 & 7,2 & 176,6 & 180,7 & 0,5 \\ \text { AL } & 75,0 & 77,0 & 9,0 & 12,1 & 192,2 & 216,7 & 2,4 \\ \text { SE } & 88,5 & 88,7 & 4,8 & 3,1 & 154,2 & 164,8 & 1,3 \\ \text { BA } & 84,1 & 82,4 & 4,4 & 5,8 & 95,5 & 99,7 & 0,9\end{array}$

Sudeste

$\begin{array}{lrrrrrrr}\text { MG } & 63,8 & 64,7 & 9,6 & 12,4 & 47,1 & 49,1 & 0,8 \\ \text { ES } & 65,8 & 72,7 & 6,5 & 11,0 & 79,7 & 81,3 & 0,4 \\ \text { RJ } & 62,6 & 62,7 & 19,1 & 20,3 & 78,4 & 80,8 & 0,6 \\ \text { SP } & 61,5 & 55,1 & 20,3 & 26,2 & 69,5 & 66,4 & -0,9 .\end{array}$

Sul

$\begin{array}{lrrrrrrr}\text { PR } & 85,6 & 80,5 & 6,7 & 8,6 & 135,5 & 133,0 & -0,4 \\ \text { SC } & 92,8 & 93,2 & 2,3 & 2,4 & 108,7 & 124,9 & 2,8 \\ \text { RS } & 90,9 & 89,9 & 4,4 & 4,6 & 60,8 & 80,0 & 5,6\end{array}$

Centro-0este

$\begin{array}{lrrrrrrr}\text { MT } & 83,2 & 79,7 & 8,8 & 10,8 & 8,1 & 10,3 & 4,9 \\ \text { GO } & 70,8 & 67,5 & 7,7 & 10,3 & 15,3 & 15,9 & 0,8\end{array}$

Fonte: CENSOS AGROPECUARIOS 1970/1975. 
variāvel se manteve bastante estāvel. A queda em São Paulo decorre possivelmente da expulsão de alguns proprietários e da saỉda de famīlias do campo, substituĩdos por böias-frias. Jā no Espīrito Santo possivelmente a pulverização da pequena propriedade tenha levado a : uma ampliação da participação dos responsāveis e membros da famỉlia.

Na região Sul, apenas no Estado de Santa Catarina hā um crescimento da participação dos responsāveis no total de pessoal ocupado, possivelmente com as mesmas causas do Espīrito Santo. Enquanto que no Paranā hā um grande crescimento da participação dos trabalhadores permanentes.

No Centro-0este hā um decréscimo da participação $\operatorname{dos}$ responsāveis e hā um crescimento dos trabalhadores permanentes.

0 progresso técnico da agropecuāria parece não afetar a produtividade física da terra, como visto na TABELA 2.6. A partir da TABELA 2.20 analizaremos as alterações que houve em termos dos rendimentos por homem ocupado, nos diversos estados. Apesar das imperfeições dos dados; $j \bar{a}$ apresentados no item 2.3.1, essas comparações contribuem para a anālise. 0 rendimento aqui é entendido como sendo o valor global gerado pela produção agropecuária menos o consumo interno.

0 crescimento geral do rendimento por homem ocupado para quase todos os estados nos dā uma indicação de que a produção agrícola tem apresentado uma elevação acentuada da produtividade do trabaTho. Os maiores nĩveis de rendimento são observados em São Paulo, Rio Grande do SuT, Rio de Janeiro, Paranā e Goiās em 1975 ..

Apesar do grande crescimento do rendimento por homem ocupado na região Nordeste, observa-se para 1975 valores substantivamente menores que nas demais regiões, indicando sua baixa produtividade do trabalho. 
TABELA 2.20. Rendimento por hectare e Rendimento por homem ocupado na Agricultura - Cr\$ mil de 1977 (a)

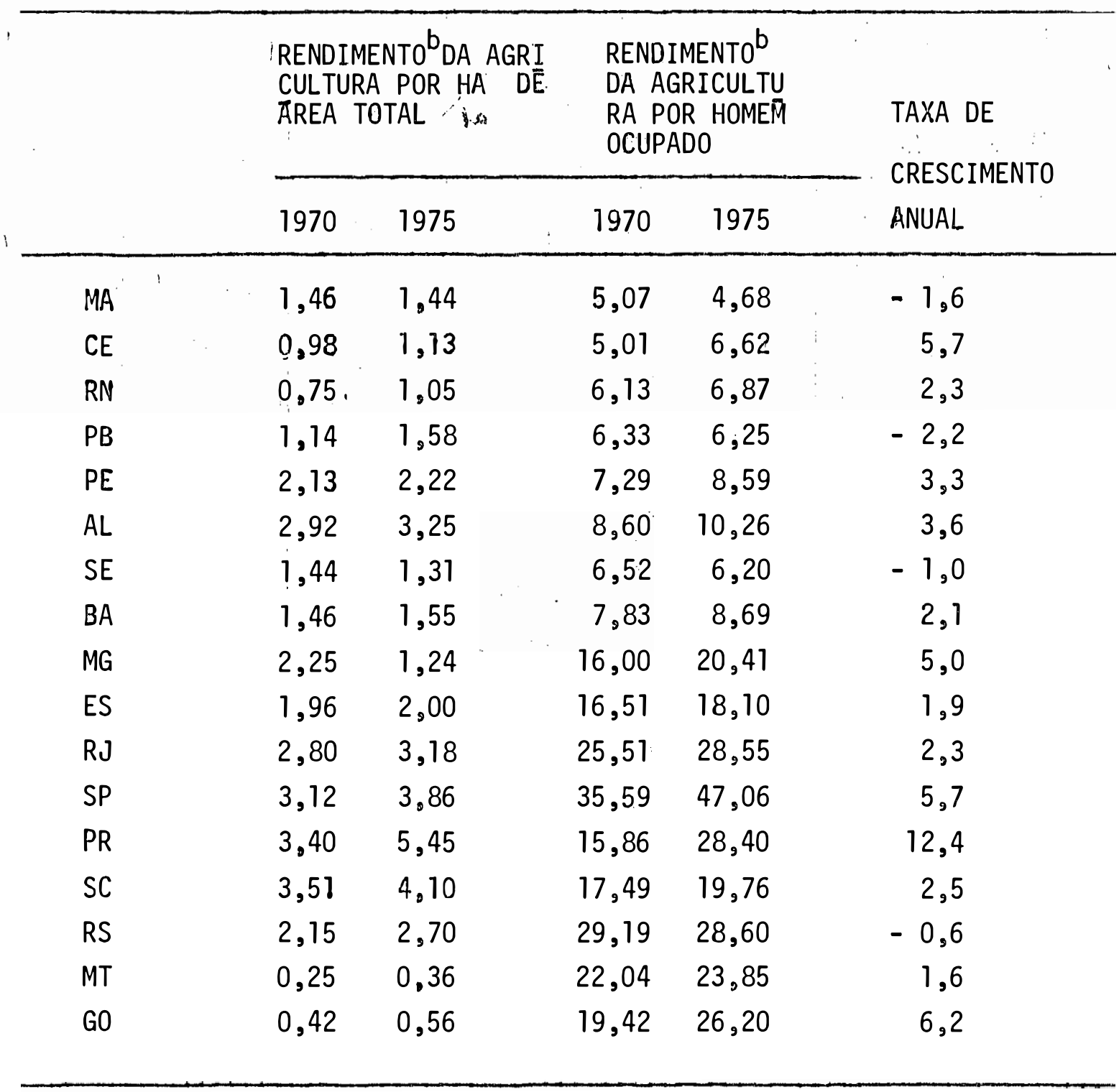

FONTE: CENSOS AGROPECUARIOS de 1970 e 1975

a)-Valor da Produção - Deflacionado pelo Indice de Preços Recebidos pela Agricultura da F.G.V.. -

- Consumo Interno - Deflacionado pelo Indice de Preços Pagos pela Agricultura - F.G.V.

b) - Rendimento $=$ Valor da Produção - Valor do Consumo interno (Despesas - salārio - Cota parte do roceiro - Empreitada - juros bancārios ) 
Entre os estados do Nordeste, Alagoas e Pernambuco, se destacam com os indices mais altos.

0 fato dos trabalhadores agrïcolas passarem crescentemen te a apenas contar com os salários obtidos, e não mais cóm a possibilida de de estabelecer pequenos cultivos que garantem a subsistência, faz com que a anālise dos salārios na agricultura se torna mais díficil. Caberia aqui uma comparação entre o crescimento dos salärios e o crescimento dos rendimentos por homem empregadọ,que não serā feito pelas razões acima apontadas . 
2.3.1.3. Uma Tentativa de Sỉntese do Progresso Técnico

A existência de diversos indicadores, às vezes com influên cias distintas, na configuração do nīvel técnico e do grau de capitaliza ção da produção agropecuāria, nos levou a tentar uma sĩntese das mesmas, atravēs do mētodo de componentes principais.

Os componentes principais são os obtidos atravēs da combina ção linear das seguintes variāveis, onde as despesas são em milhões de cruzeiros correntes:

DMSA : Despesa em salārio por hectare de ārea total

DMAN : Despesa com animais por hectare de pecuāria

DMTT : Despesa total por hectare de ārea total

DLAV : Despesa da lavoura ((adubos e corretivos, sementes e mudas, defen sivos) por hectare de lavoura

AAN : Nūmero de arados de tração animal por hectare de lavoura

AME : Nūmero de arados de tração mecânica por hectare de lavoura

TRA : Nümero de tratores por hectare de lavoura

DFIN : Despesa financeira por hectare de ārea total

DMOU': Outras despesas por hectare de ärea total

VALM : Valor de māquinas por hectare de lavoura

VBEM ${ }^{1}$ : Valor total dos bens por hectare de ārea total

7. Conforme defiñi ção dos Censos Agropecuārios de 1970 e 1975. 
As variāveis utilizadas visam exatamente captar a combinação do nîvel técnico e do grau de capitalização da agricultura dos diversos estados. As variāveis como tratorização, arados mecānicos, despesas com lavouras, despesas com animais, arados de tração animai de al guma forma captam o nỉvel técnico da produção, enquanto as demais captam o nĩvel de monetização e de capitalização da agricultura.

0 primeiro componente principal è a combinação linear de maior variāncia de uma série de variāveis, que para nōs são as 11 anteriormente definidas. Como podemos observar nas TABELAS 2.24 e 2.25, o $A_{1}$ de 1970 explica 0,634 da variāncia, enquanto em 1975 explica 0,690 . Podemos notar que o poder explicativo dos primeiros componentes principais em ambos os anos'é bastante elevado.

Os pesos dos fatores (Factor Loadings) indicam a correlação que hā entre as variāveis e o componente principal. Neste sentido, tanto em 1970 como em 1975 podemos observar que o primeiro componente principal tem correlações positivas e relativamente elevadas com todas as variāveis.

As alterações que ocorreram nas correlações entre as variāveis e o primeiro componente principal são bastante significativas. Isto é, arados mecânicos, tratores, despesas financeiras, despesa total, outras despesas, o valor das máquinas, o valor dos bens e arados de tração animal tem uma maior correlação com o primeiro componente principal em 1975 do que em 1970.

As correlações das despesas de lavoura

permaceceram constantes entre 1970 e 1975, enquanto as correlações entre despesas com animais e despesas com salārios e o componente principal cairam entre 1970 e 1975. De alguma forma, as correlações que se elevaram indicam uma maior participação destas variāveis na formação do componente principal. Isto significa que as despesas com salários e as despesas com animais tem uma menor participação da formação do componente principal de 1975, indicando tambēm que são menos significativos para explicar o grau de capitalização e o nĩvel técnico em 1975. 


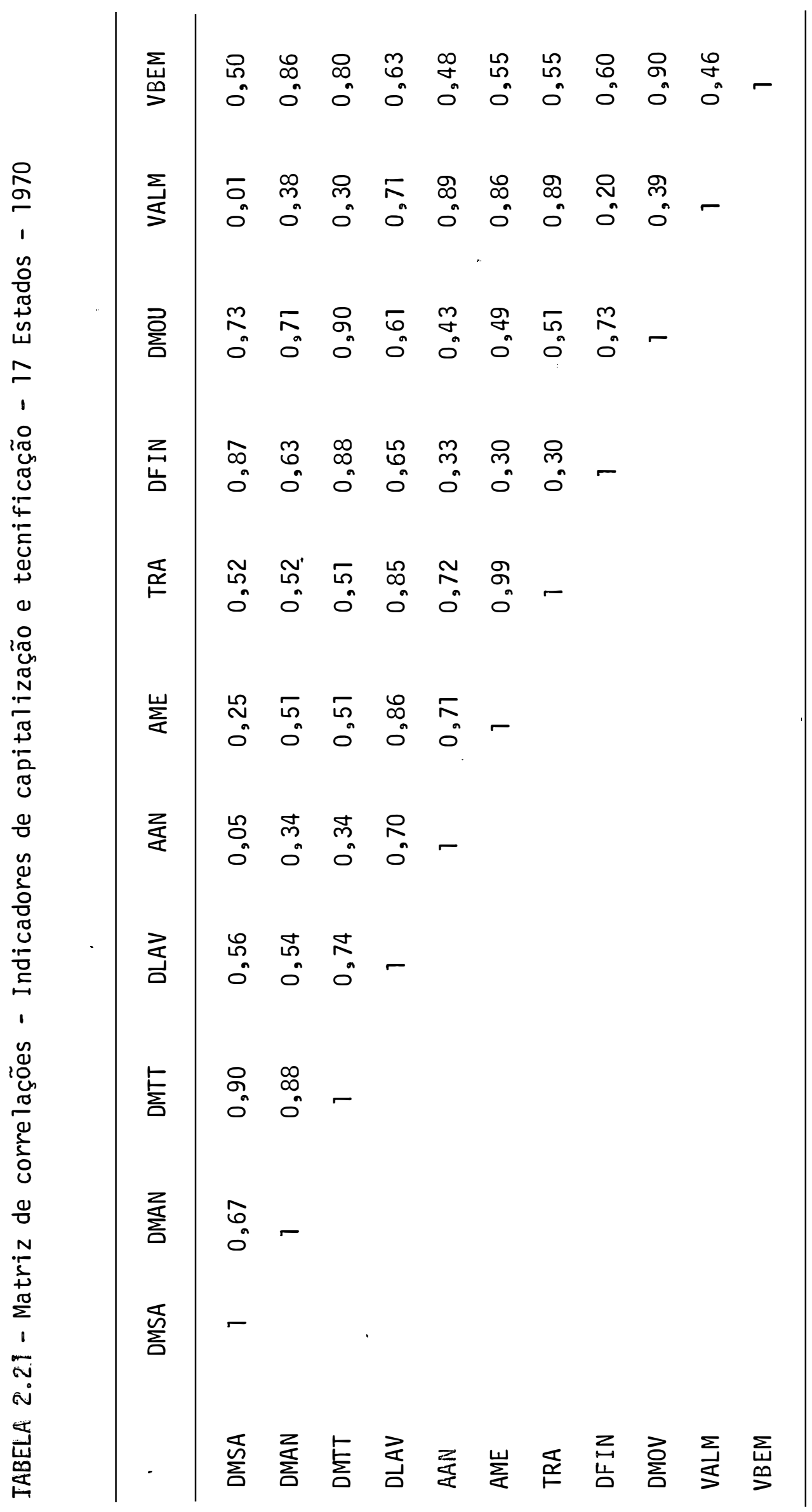

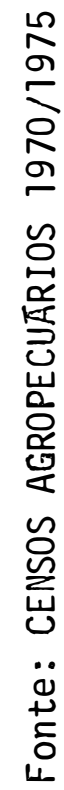




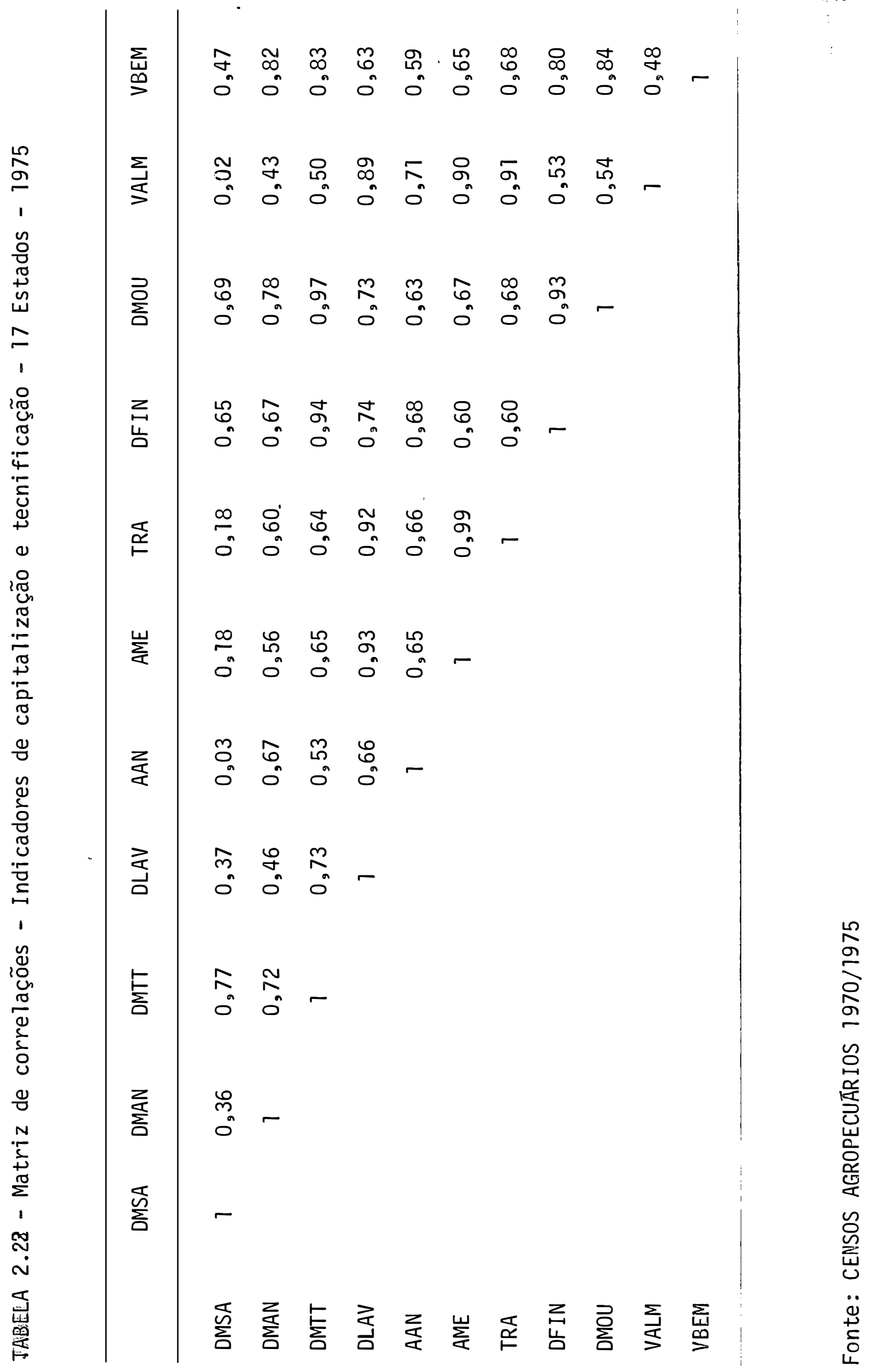


JABELA 2.23 - Peso dos Fatores do nỉvel de tecnificação - 1970-11 variāveis para 17 Estados

PESO DOS FATORES

\begin{tabular}{cccc} 
& $A_{1}$ & $A_{2}$ & $A_{3}$ \\
\hline DMSA & 0,672 & 0,638 & 0,322 \\
DMAN & 0,837 & 0,313 & $-0,361$ \\
DMTT & 0,895 & 0,426 & 0,064 \\
DLAV & 0,894 & $-0,210$ & 0,322 \\
AME & 0,802 & $-0,518$ & 0,056 \\
TRA & 0,805 & $-0,525$ & 0,032 \\
DF IN & 0,745 & 0,485 & 0,337 \\
DMOU & 0,871 & 0,352 & $-0,273$ \\
VALM & 0,684 & $-0,688$ & $-0,045$ \\
VBEM & 0,849 & 0,165 & $-0,417$ \\
AAN & 0,658 & $-0,583$ & 0,062 \\
Fração acumulada & & & 0,924 \\
da variação & 0,634 & 0,859 & \\
explicada & & & \\
\hline
\end{tabular}


TABELA 2.24 - Peso dos Fatores do nîvvel de tecnificação - 1975 variāveis para 17 Estados

\begin{tabular}{|c|c|c|c|}
\hline & \multicolumn{3}{|c|}{ PESO DOS FATORES } \\
\hline & $A_{1}$ & $A_{2}$ & $A_{3}$ \\
\hline DMSA & 0,499 & 0,752 & 0,376 \\
\hline DMAN & 0,778 & 0,174 & $-0,511$ \\
\hline DMTT & 0,907 & 0,392 & 0,097 \\
\hline DLAV & 0,895 & 0,269 & 0,324 \\
\hline AME & 0,870 & 0,410 & 0,171 \\
\hline TRA & 0,880 & $-0,400$ & 0,128 \\
\hline DF IN & 0,894 & 0,305 & $-0,011$ \\
\hline DMOU & 0,930 & 0,318 & $-0,019$ \\
\hline VALM & 0,775 & $-0,573$ & 0,151 \\
\hline VBEM & 0,861 & 9,209 & $-0,235$ \\
\hline$\because A A N$ & 0,760 & $-0,289$ & $-0,418$ \\
\hline $\begin{array}{l}\text { Fração acumulad } \\
\text { da variância } \\
\text { explicada }\end{array}$ & 0,690 & 0,854 & 0,928 \\
\hline
\end{tabular}


As altas correlações entre o primeiro componente principal: com o preço da terra de lavoura, com o crēdito total concedido e com a rentabilidade por homem empregado, apresentados na TABELA 2.26, indicam que o nĩvel tecnológico e grau de capitalização tem uma forte ligação com estas variāveis. E mais do que isso, que a relação en tre estas variāveis se elevou no perỉodo de grande incorporação de no vas técnicas, principalmente a rentabilidade por homem empregado.

TABELA 2.25 - Correlações do 10 componente principal, com preço da terra, crédito total e rentabilidade por homem ocupado para 17 Estados - 1970 e 19.75

\begin{tabular}{|c|c|c|c|c|}
\hline & & $\begin{array}{l}\text { PREÇO DA } \\
\text { TERRA DE } \\
\text { LAVOURA }\end{array}$ & $\begin{array}{l}\text { CREDITO } \\
\text { TOTAL } \\
\text { CONCEDIDO }\end{array}$ & $\begin{array}{l}\text { RENTABILIDA- } \\
\text { DE POR HOMEM } \\
\text { OCUPADO }\end{array}$ \\
\hline 1970 & $\begin{array}{c}\text { Componente } \\
\text { Principal }\left(A_{1}\right)\end{array}$ & 0,84 & 0,82 & 0,62 \\
\hline 1975 & $\begin{array}{c}\text { Componente } \\
\text { Principal }\left(A_{1}\right)\end{array}$ & 0,91 & 0,87 & 0,79 \\
\hline
\end{tabular}

\subsubsection{Alterações na Distribuição da Propriedade da Terra}

Em diversos momentos deste trabalho abordamos a questão de que a Modernização Conservadora tem um efeito substantivo sobre a concentração da propriedade da terra. 0 processo de concentração da propriedade da terra estā vinculadò ao prōprio processo de subordinação da agricultura ao capital. A TABELA 2.27 nos indica que houve concentração da posse em muitos do 17 estados aqui analisados. Devemos ter claro que este processo não ē generalizado, havendo estados onde inclusive hā uma queda nesta concentração.

Excetuando-se os estados do Cearā, Pernambuco, São Pau10. Rio Graride do Sul e Mato Grosso, todos os demais sofreram incre- 
TABELA 2.26 - Indice de Gini (G*) da distribuição da posse da terra pelos estabelecimentos agropecuārios no Brasii, por Unidades da Federação, de acordo com os Censos de 1970 e $1975^{1}$.

\begin{tabular}{lll}
\hline & 1970 & 1975 \\
\cline { 2 - 3 } Maranhão & 0,926 & 0,927 \\
Cearā & 0,791 & 0,784 \\
Rio Grande do Norte & 0,853 & 0,862 \\
Paraība & 0,823 & 0,847 \\
Pernambuco & 0,838 & 0,829 \\
Alagoas & 0,836 & 0,846 \\
Sergipe & 0,854 & 0,855 \\
Bahia & 0,801 & 0,812 \\
Minas Gerais & 0,751 & 0,756 \\
Espīrito Santo & 0,604 & 0,628 \\
Rio de Janeiro & 0,790 & 0,791 \\
São Paulo & 0,779 & 0,775 \\
Paranā & 0,702 & 0,729 \\
Santa Catarina & 0,647 & 0,659 \\
Rio Grande do Sul & 0,756 & 0,755 \\
Mato Grosso & 0,929 & 0,927 \\
Goiās & 0,738 & 0,749 \\
\hline
\end{tabular}

FONTE: Dados bāsìicos dos CENSOS AGROPECUARIOS de 1970 e' 1975. No cálculo do ĩndice de Gini foram incorporados estimativas das desigualdades dentro dos estratos de ārea, admitindo que a dis tribuição dentro do estrato tenha função de densidade linear ou de Pareto com dois parâmetros.

${ }^{1} 0$ Indice de Gini è uma medida do grau de concentração de uma distribuição qualquer. 0 índice varia de zero (igualdade absoluta) atē um (concentração absoluta). Assim, quanto mais elevado o valor que assumè o Indice de Gini, maior o grau de concentração de uma distribuição qualquer. 
mento de seu îndice de Gini indicando uma elevação do graude concentração da propriedade da terra.

Devemos atentar para o fato de que o grau de concentração da propriedade da terra no Brasil jā era, antes da Modernização Conservadora, bastante elevado. E o processo de modernização a fetou a propriedade da terra de distintas formas em cada estado em função da formação histörica dos mesmos, is to $\bar{e}$, desde os tipos de culturas existentes e suas condições de mercado, o relevo, o clima, as prōprias especificidades da estrutura da propriedade da terra, etc. Aqui pretendemos observar apenas qual a relação entre a modernização da agricultura e as mudanças mais gerais da estrutura fundiāria, sem adentrarmos nos aspectos histōricos de sua formação.

Não nos esqueçamos de que o conceito de estabelecimento alterou-se no Censo de 1975. O fato de no Censo de 1975 os estabelecimentos englobarem āreas não contĩnuas afeta o īndice de Gini, pois hā menos estabelecimentos para uma mesma ārea. Mas a observação dos dados do INCRA de $1978^{1}$ dão indicações de elevação de concentração para alguns Estados, geralmente os mesmos que são apontados pelos dados dos Censos.

Podemos observar que as elevações mais acentuadas do Indice de Gini, pela ordem, se deram nos estadós do Paranā, Ëspírito Santo, Paraỉba, Santa Catarina, Goiās, Bahia, Alagoas. E que os estados que tinham os nīveis de concentração relativamente mais baixos, em 1970 (pela ordem Espīrito Santó. Santa Catarina, Paranā e Goiās), participam do grupo de estados onde o grau de concentração mais se elevou.

"Vide GRAZIANO DA SILVA, J. e HOFFMANN, R. - "A reconcentração Fundiāria". In Reforma Agräria ano $X, n 0.6$, pp 3 a 17. 
No Nordeste observamos em 1970 os mais elevados nîveis de concentração da propriedade da terra do Brasil. O segundo Estado com menor concentração desta região è a Bahia, que tambëm sofre um intenso processo de concentração da propriedade da terra.

Concluî̉mos daĩ que hā uma relação entre a elevação do grau de concentração da propriedade da terra e o nĩvel de concentração em 1970, isto é, os Estados onde havia a mais baixa concentração em 1970 estão entre os que mais se concentraram. Isto se deve à prôpria polītica agrî́cola e principalmente, a política de crēdito, que incentivaram a produção em grandes estabelecimentos. Alēm, é claro, de todo o sentidoda modernização, como $j a \bar{a}$ apontado, favorecer a concentração da propriedade.

Por outro 1ado, apesar de em todos os Estados do Brasil haver um incremento bastante acentuado da utilização de técnicas modernas, podemos observar; na TABELA 2.28, que o nīvel técnico e o grau de capitalização, se elevaram de forma distinta nos diversos Estados. No Nordeste, a variação do componente principal cbtido indica que Alagoas e Paraỉba sofreram as maiores elevações na modernização. Jā no Sudeste, apesar do crescimento do nīvel tēcnico ter sido bastante generalizado, Minas Gerais e São Paulo despontam com os maiores crescimentos .

No Sul, Santa Catarina e Paranā tem crescimentos significativos da utilização de técnicas modernas. Enquanto no Centro-Oeste, o Mato Grosso aparece com uma grande variação no seu nỉvel técnico.

As informações da TABELA 2.28 indicam que o acentuado crescimento do nĩvel de capitalização se relaciona com uma elevação do grau de concentração. Como exemplos disso observamos Alagoas, Paraíba, Santa Catarina e Paranā. A correlação existente entre a variação do nĩvel de capitalização e a variação do Indice de Gini, apesar de baixa $(+0,12)$, ratifica a relação positiva entre capitalização e concentraçã̃o.

Depreende-se daî que a Modernização Conservadora, que de alguma forma atinge a quase totalidae dos Estados do Brasil, tem relação com a elevação da concentração da propriedade da terra de 3 formas distintas e interrelacionadas.

a) Os Estados com menores nĩveis de concentração da pos- 
TABELA 2.27 Nível de tecnificação e capitalização obtido pelo método de componentes principais para 1970 e 1975 e sua taxa de crescimento anual

\begin{tabular}{|c|c|c|c|}
\hline & 1970 & 1975 & Taxa de Crescimento anual $(\%)$ \\
\hline MA & 0,264 & 1,649 & 44,2 \\
\hline CE & 0,474 & 2,319 & 37,4 \\
\hline RN & 0,420 & 2,661 & 44,7 \\
\hline PB & 0,542 & 4,343 & 51,6 \\
\hline$P E$ & 0,856 & 4,832 & 41,4 \\
\hline$A L$ & 1,127 & 9,470 & 53,1 \\
\hline SE & 0,951 & $6 ., 064$ & 44,8 \\
\hline$B A$ & 0,840 & 5,155 & 43,7 \\
\hline$M G$ & 0,155 & 5,994 & 55,7 \\
\hline ES & 1,019 & 8,471 & 52,7 \\
\hline RJ & 1,709 & 14,365 & 53,1 \\
\hline SP & 2,287 & 19,731 & 53,9 \\
\hline PR & 2,049 & 15,260 & 49,4 \\
\hline SC & 1,403 & 12,139 & 54,0 \\
\hline RS & 1,471 & 11,050 & 49,7 \\
\hline MT & 0,375 & 3,950 & 60,1 \\
\hline Go & 0,388 & 3,194 & 52,4 \\
\hline
\end{tabular}

Fonte dos Dados Originais: CENSOS AGROPECUARIOS 1970 e 1975 
se da terra em 1970 sofreram um incremento acentuado dessa concentração, ao mesmo tempo que tiveram seu nỉvel de capitalização elevado. Os principais exemplos deste processo são: o Espīrito Santo e Santa Catarina.

b) Os Estados com nĩveis relativamente baixos de concentração da propriedade da terra tiveram acentuada elevação do rendimento por homem ocupado. (TABELA 2.20). Os principais Estados que se enquadram neste caso são: Paranā e Goiās.

c) Os Estados nos quais a concentração da propriedade da terra jā era relativamente elevada e apresentaram uma acentuada elevação do nî̉vel de capitalização tiveram um crescimento na concentração da propriedade da terra bastante acentuado. Alagoas e Paraîba são exemplos desse caso.

Hā ainda o Estado da Bahia, no qual observamos um aumen 'co da concentração da posse da terra, mas não apresenta um crescimento excepcional do nîvel de capitalização ou do rendimento por homem empregado.

Cabe frisar que hā Estados como Mato Grosso, Minas Gerais, São Paulo, Rio de Janeiro, Sergipe e outros, onde apesar de haver uma substantiva elevação da utilização de técnicas modernas, houveram decrēscimos ou pequenas elevações de concentração da posse da terra. Isto pode advir tanto de uma jā alta concentração da posse da terra, ou de que as alterações ocorridas a nīvel de Modernização Conservadora não a fetaram a propriedade da terra de forma significativa.

Neste sentido podemos compreender adequadamente o porque de se chamar este processo de Modernização Conservadora, pois moderniżou-se alterando a estrutura fundiāria (no sentido da concentração) somente nos Estados onde a concentração não era tão grande.

\subsection{Resumo do Capítulo}

- 0 processo de industrialização da agricultura que se deu entre 1970 e 1975 foi :. $\quad$ mais intenso do que no período 1960/ 1970. 
- A industrialização voltou-se basicamente para os grandes e médios estabelecimentos. Mas a utilização de técnicas modernas também aumentou em muitos pequenos estabelecimentos. Com isso queremos deixar claro que, apesar de haver um processo de expropriação da pequena produção, a forma predominante de se subordinar esta produção ao capital è atravēs de sua tecnificação.

- A quase totalidade da tecnologia disponĩvel para a industrialização da agricultura brasileira é voltada para os grandes e médios estabelecimentos ${ }^{1}$.

- A industrialização da agricultura alterou a utilização de força de trabalho gerando uma demanda maior de mão-de-obra temporāria e de mão-de-obra permanente nos pequenos e grandes estabelecimentos respectivamente. Alēm disso, houve uma elevação de utilização de mãode-obra contratada por empreiteiros. ("bóias-frias") que se deu de forma generalizada, mas provavelmente concentrou-se nos grandes e médios estabelecimentos.

- A alteração econōmica mais significativa decorrente da industrialização da agricultura é o crescimento acentuado de produtividade por homem ocupado,que foi da ordem de $3,6 \%$ ao ano no perĩodo 1970 a 1975.

- No Nordeste, os Estados que mais se tecnificaram no perīodo 1970/75 foram Alagoas e Paraíba, sendo este processo também bastante intenso em Sergipe e no Rio Grande do Norte. Comparativamente às demais regiões, esta tem um nīvel de tecnificação bastante baixo.

- O Sudeste, que jā apresentava em 1970 altos nĩveis de tecnificação, sofreu incrementos substantivos na utilização de técnicas

IVide GUIMARES (1979), pp. 300 a 302. 
modernas no periodo 1970/75. Os Estados nos quais mais cresceu a utili: zação de tēcnicas são:São Paulo e Minas Gerais.

- No Sul, Santa Catarina e Paranā aparecem com os maiores crescimentos na utilização de técnicas modernas. Destaque deve ser dado ao Paraná pelo grande crescimento do rendimento por homem ocupado.

- 0 Centro-Oeste apresentou uma pequena elevação do rendimento por homem ocupado; apesar disso, observamos uma acentuada elevação do nỉvel tecnolögico no Mato Grosso. 0 crescimento da mecanização mui to provavelmente esteve associado à ocupação da fronteira.

- 0 processo de concentração da posse da terra entre 1970 e 1975 foi significativo em muitos Estados. Este processo foi mais intenso nos Estados onde a concentração era menor ou onde havia pouca tecnificação da agricultura. Disto concluīmos que a modernização contribui para o processo de concentração da posse da terra.

- As al terações que ocorreram na agricultura brasileira entre 1970 e 1975 foram bastante significativas. Entretanto devemos ter em mente que todo esse processo foi viāvel e possĩvel dado um perĩodo da fartura na economia brasileira como um todo, perīodo este que usualmente chamamos de "Milagre Brasileiro", no qual a economia brasileira cresceu a taxas acima de 10\% ao ano. 


\section{A POLITICA DE CREDITO RURAL}

A TABELA 3.1 nos mostra claramente que o incremento dos montantes de créditos concedidos à agricultura brasileira no perīodo 1969-79 ē bastante elevado. Por outro 1ado, hā uma grande concentração do crédito nas grandes e médias propriedades. Além do que, hā um consenso de que apenas parte deste crêdito foi utilizado na pröpria produção. Cade perguntar qual foi o real papel desta polïtica creditícia dentro do processo de subordinação da agricultura ao capital.

Para GUEDES PINTO (1980) as caracterîsticas da polîtica de crēdito rural estão intimamente ligadas à necessidade de manutenção do status quo no setor rural, ou seja, enquanto elemento que participa das transferéncias de rendas de outros setores para o setor rura1. Visto que este setor, segundo o autor, deixaria de obter parte dos lucros aos quais faria jus se não houvesse uma política de contenção de preços dos alimentos e de confisco cambial.

De acordo com GUEDES PINTO, este processo de concentração de riqueza se dā basicamente atravēs: a) da prōpria concentração dos recursos desta polītica; b) da elevação do preço da terra que esta política possibilita; c) dos desvios dos recursos do crëdito rural para outros setores de maior lucratividade.

Por outro 1ado, SAYAD (1978) procura basicamente fazer uma avaliação parcial da eficiência do programa de crédito rural brasileiro, alēm de propor mudanças nesta politica no sentido de elevar esta 
JABELA 3.1 - Renda Interna do Setor Primärio e o Volume de Recursos Concedidos pelo Sistema Nacional de Crëdito Rural - 1969 1979 (Em Cr $\$ 1.000 .000)$ - Brasil

\begin{tabular}{cccc}
\hline ANO & $\begin{array}{c}\text { RENDA INTERNA } \\
\text { DA AGRICULTURA } \\
(\mathrm{A})\end{array}$ & $\begin{array}{c}\text { CREDITOS CONCE- } \\
\text { DIDOS }- \text { SNCR } \\
(\mathrm{B})\end{array}$ & $\frac{(\mathrm{B})}{(\mathrm{A})} \times 100$ \\
\hline 1969 & 14.336 & 6.489 & 45,3 \\
1970 & 17.127 & 9.248 & 54,0 \\
1971 & 23.973 & 12.870 & 53,7 \\
1972 & 30.560 & 18.669 & 61,1 \\
1973 & 44.270 & 30.334 & 68,5 \\
1974 & 65.657 & 48.273 & 73,5 \\
1975 & 87.820 & 89.997 & 102,5 \\
1976 & 137.703 & 130.226 & 94,6 \\
1977 & 236.849 & 165.858 & 70,0 \\
1978 & 320.670 & 233.942 & $73,0$. \\
1979 & 520.608 & 448.731 & 86,2 \\
\hline
\end{tabular}

Fonte: F.G.V., CONTAS NACIONAIS

CONCRED - 6 volumes, citado por GUEDES PINTO (1980). 
eficiência. Dentro deste objetivo mais amplo, podemos notar que para o autor esta política tem tido alguns papēis bastante claros. Além dos ligados à produtividade dos fatores, tecnologia aplicada e produção do setor agrīcola, que o autor não analisa, o principal papel que esta política tem tido refere-se ao aumento da desigualdade existente na distribuição da riqueza. Isto porque esta política, alēm de atingir basicamente os maiores produtores, nem sempre è suficientemente fiscalizada, gerando desvios de recursos bastante elevados. Para o autor nem o objetivo de indução de adoção de novas técnicas sofreu incrementos suficientemente elevados para justificar os excessivos gastos. em termos desta política.

Em outro texto SAYAD (1977, p. 653) coloca que a "elevação dos preços da térra rural no Brasil deve estar associada não sō à melhoria dos termos de troca em favor da agricultura e à derrocada no mercado de ações, mas tambēm aos direitos de crēdito subsidiado que gerava". Neste sentido um outro papel que esta politica acaba exercendo è o da elevação do preço da terra agrīcola.

Mas o autor que mais aprofundou-se nos efeitos da politica de crēdito na elevação do preço da terra é REZENDE (1981ạ) ,ao constatar que os desvios de crédito são geralmente aplicados na compra de terras.

Para Rezende, na medida em que a aquisição de crédito possibilita ganhos extras, este passa a gerar uma elevação acentuada da demanda por terras agrīcolas, jā que é com terras que os capitalistas podem participar deste lucro excedente. E esta elevação de demanda, por sua vez gera uma elevação acentuada nos preços das terras. Por outro lado, Rezende coloca que a política de crédito, ao possibilitar a utilização destes recursos em setores onde os lucros são mais elevados, nega a premissa de que a demanda por investimentos agrīcolas seja uma demanda derivada da polîtica de crédito. Dadas estas caracterīsticas da política de crédito, o autor entende que esta politica, em nada participa da manutenção de baixos preços agrĩ̄colas. Neste sentido, sua retirada em nada afetaria os preços de produção. 
Brasileira", faz um estudo acerca da evolução recente da agriculturä brasileira e das relações entre as diversas classes. Para o autor 0 crédito rural é o instrumento mais importante de modernização da agricultura e esta polītica tem dois aspectos bāsicos. "Por um lado visa modernizar as forças produtivas, e desse ponto de vista pode ser considerado como um crédito para o conjunto do complexo agroindustrial que, como veremos, se favorece mais do crédito rural do que o prōprio setor agrícola. Por outro, trata de compensar a política de controle de preços, sendo uma transferência de renda especialmente para os médios e grandes produtores, que tem maiores condições de reagir contra essa poTitica "(SORJ, 1980, .P. 89)。

Mas SORJ tambēm insiste em que o crēdito rural privilegiou certo tipo de produtor e de produto, além de que parte destes recursos foi desviado; para atividades urbanas ou para a compra de terras.

0 que de fundamental SORJ coloca è que a polītica de crēdito, no seu intento de modernizar, levou a:

a) um incentivo à concentração de terras

b) Uma transformação qualitativa das características de parte da pequena produção (de algumas regiões) no sentido de sua concentração e de sua capitalização, gerando em contrapartida a pauperização e semiproletarização dos pequenos produtores tradicionais.

Para GRAZIANO DA SILVA (1980), na sua tese sobre Progresso Técnico na Agricultura, a polītica de crédito tem três funções bāsicas que são interdependentes:

a). Possibilita que os proprietārios recebam parte do sobre-lucro (em forma de renda da terra), jā que o tabelamento dos preços agrî́colas tornaria inviāvel, na usência do crédito subsidiado, a gera- . ção desse sobre-lucro.

b) Possibilita o processo de acumulação do setor industrial com a ampliação da venda de insumos agrícolas.

c) E ao possibilitar o sobre-lucro para alguns proprie- 
tários e a consequente valorização patrimonial, dada pela elevação do preço da terra, torna-se um meio de acesso a mais capital dinheiro na forma de crédito subsidiado.

Podemos observar, a partir da anālise de Graziano da Silva, que a política de crédito rural exerce um papel fundamental dentro do processo de industrialização da agricultura.

Todos os estudos anteriormente citados são uma contribuição inegāvel ā compreensão do papel da política de crédito rural no desenvolvimento do capitalismo na agricultura brasileira. A partir deles e de constatações empíricas que serão apresentadas em seguida, entendemos que o principal papel da política é de viabilizar o , processo de subordinação da agricultura ao capitalismo como um todo. Os elementos centrais disto são a completa subordinação do trabalho ao capital, e a subordinação parcial da terra aos desígnios de capital. Neste processo o principal motor é a industrialização da agricultura que se fez viāvel pela imensa massa de créditos concedidos. Os latifündios, ao se industrializarem, subordinam sua produção às necessidades do capital. Tanto em termos da forma de utilização da terra quanto da forma de exploração da mão-de-obra. Já o pequeno produtor subordina-se ao ser expropriado (e se torna um trabalhador sem terra) ou quando passa a ser pequeno produtor tecnificado, totalmente subordinado $\bar{a}$ agroindūstria ou às cooperativas.

Como mostraremos no Capitulo 4, o processo de subordinação da agricultura ao capital estā relacionada com ą elevação do preço da terra. Esta elevação se dá tanto pelo processo especulativo quanto pelo aumento da renda da terra possibilitadó pela utilização de insumos modernos. Nes te sentido, çrềdi tô rural é um elemento fundamental na aceleração dessa elevação do preço da terra, tanto no processo de modernização quanto na possibiîdâde de ganhos não produtivos dada pela propriedade da terra. Ou seja, o crëdito eleva o preço da terra por 2 mecanismos: 0 especulativo (possibilidade de obtenção de mais crédito) e o produtivo (possibili-. tando maior extração de lucros). 
dão atravēs de dois mecanismos bāsicos: a) a remuneração ao montante de crédito obtido, quando ele passa a ser um simples capital aplicado em outros setores; b) o próprio subsídio, em termos de juros inferiores à inflação, que está embutido na política de crédito.

A elevação do preço da terra pela via produtiva se dá atravēs do processo de modernização, que ē viabilizado pelo crēdito, e consiste na elevação da produtividade, que por sua vez,possibilita um crescimento da renda da terra.

0 aumento da demanda por terras, gerado, pelos possīveis ganhos advindos do crédito, explicitados acima, acarreta um processo auto-alimentador de sua elevação. Isto ocorre porque, na medida em que os proprietārios podem obter ganhos produtivos ou improdutivos do crédito, sua demanda por terras elevar-se-ā, pois è a terra que possibilita estes ganhos. Assim, com a existēncia do crédito haverā uma constante elevação do preço da terra.

Mas o crēdito, tanto pelo seu efeito produtivo quanto pelo especulativo, tem gerado uma al ta concentração da posse da terra. Is to ocorre, por um lado, porque os grandes produtores, que tem maior acesso ao crédito, compram mais terras. Por outro lado, a prōpria modernização que o crédito possibilita acaba por concentrar a posse da terra, dado que ela se volta mais para as culturas tîpicas de grande propriedade.

0 crēdito rural tambēm teve um papel inegável na abertura e ocupação da fronteira, tanto atravēs da especulação quanto atravēs do processo produtivo em $\mathrm{si}$, isto $\bar{e}$, possivelmente a fronteira agrỉcola teria sido ocupada mais lentamente se não houvesse 0 incentivo da política creditîcia para a compra e ocupação do solo.

Cabe salientar que a política de crédito rural no Brasi1 no perĩodo 1970 - 1975 teve um efeito avassalador em termos das alterações do processo produtivo agrīcola. Mas jā traz no seu bojo contradições, que podem ser caracterizadas pela massa de assalariados ou semi-assalariados que surgem dentro desta modernização e que acabàm por se dirigir às cidades. Por outro lado, todas as lutas por ter- 
ras, alēm do grande crescimento da concentração de rendo na agriculitura? são consequências diretas do processo de subordinação da agricultura que se observa desde os anos 60 .

\subsection{Crēdito Rural - Principais Características}

A anālise dos principais estudos acerca do crédito rural evidencia a unanimidade entre os mesmos, no sentido de que apcntam como o principal elemento embutido nesta política a sua forte concentração ${ }^{2}$. Estes estudos também salientam o acentuado crescimento, principalmente atē 1976, dos montantes de crédito concedidos e dos subsīdios em termos de juros que eram presentes nesta política.

A TABELA 3.1, referendando os trabalhos citados, demonstra claramente que entre 1969 e 1975 o montante de recursos destinados à política de crédito cresceu de forma surpreendente.

Os estudos acima citados já apresentaram de uma forma ou de outra, as principais caracterîsticas da política de crēdito, para o Brasil, durante os ūltimos anos. Neste sentido temos claro, principalmente a partir de GUEDES PINTO (1980), que a política de crédito tem se caracterizado por:

a) Um grande crescimento nos montantes distribuīdos atē 1975.

b) Uma grande concentração do crēdito concedido.

c) Um direcionamento do crédito para alguns produtos.

d) Privilegiar algumas regiões.

3.1.1. 0 Crescimento dos Montantes Distribuídos

A TABELA 3.2 dā clara indicação de que os montantes de crédito concedidos à lavoura destinados aos diversos Estados tiveram

\footnotetext{
'Para maiores detalhes acerca da concentração da renda na agricultura vide REFORMA AGRARIA - ABRA $12(4): 40-43$ e KAGEYAMA, A. e GRAZIANO DA SILVA, J. (1983).

${ }^{2}$ Vide GUEDES PINTO (1979), SAYAD (1978), RIBEIRO (1979), REGO (1980), GUEDES PINTO (1980), GUIMARAES (1979).
} 


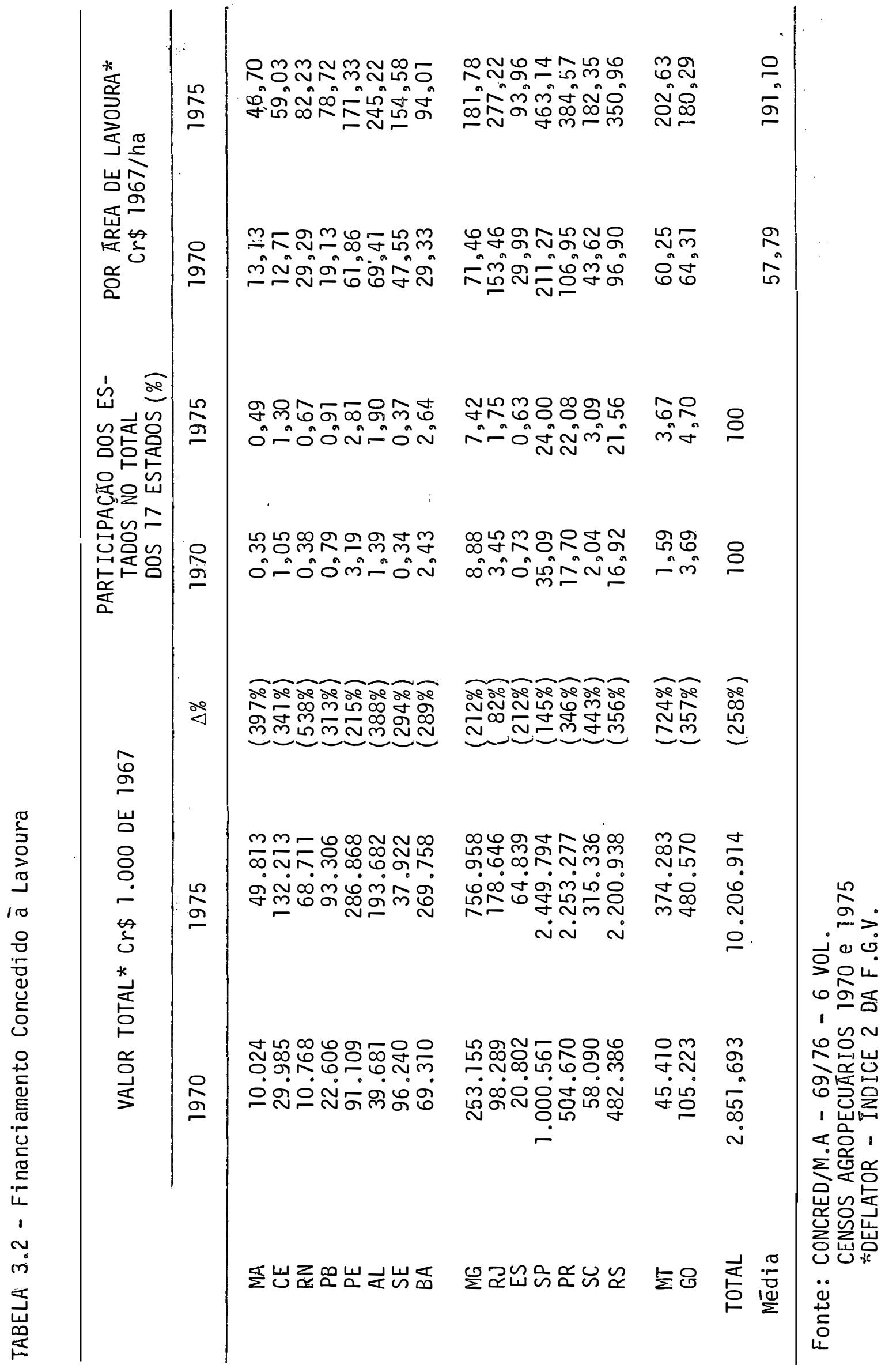


um crescimento real acima de $200 \%$ nos cinco anos. Na maior parte dos Estados o crescimento do crédito concedido foi superior a 300\%, atingindo no Rio Grande do Norte e no Mato Grosso valores acima de $500 \%$.

A participação relativa dos Estados do Sudeste no mon tante geral de crédito concedido à lavoura indica mais uma vez a forte concentração regional desta polītica. Entre 1970 e 1975 houve uma pequena desconcentração, na qual São Paulo e Minas Gerais são os Estados que mais perdem em termos de participação relativa. Mas em termos gerais, apesar do montante global sofrer um grande crescimento, as participações relativas mantēm-se relativamente inalteradas. A observação dos montantes financiados por hectare de lavoura mostra que na realidade seu crescimento, apesar de ser significativo, acaba sendo um pouco diluĩdo em relação ao 'crescimento global, pela incorporação de novas areas. No Estado de Mato Grosso, por exemplo, que apresentava um crescimento surpreendente em termos do montante global de crédito, quando este é dividido pela ārea de lavouras, fica claro que tal crescimento do crēdito correspondeu à ocupação de uma maior āreal.

\subsubsection{O valor do Crëdito por hectare de lavoura}

A anālise da política de crédito deve ser feita segundo dois critérios: o crescimento do montante global de crédito e o crescimento de valor do crēdito por hectare de lavoura.0 montante global de crēdito estā associado à disseminação de tecnologia, e ao grau de modernização da agricultura, ao passo que o valor do crēdito por hectare estā associado à intesidade de uso de insumos modernos.

Neste sentido podemos observar, a partir da TABELA 3.3, que o crescimento no montante global de crédito foi maior nos Estados onde se observou os menores montantes de crēdito por hectare no ano de

\footnotetext{
10 Mato Grosso teve um crescimento de $19,6 \%$ ao ano em sua ārea de lavouras durante o quinquēnio $70 / 75$ como se observa na TABELA 2 do
} Apêndìce. 
TABELA 3.3 - Crédito para Lavoura por hectare de lavoura

\begin{tabular}{|c|c|c|c|}
\hline & \multicolumn{2}{|c|}{ Cr\$ de 1977 / ha } & \multirow{2}{*}{$\begin{array}{l}\text { VARIACAAO NA } \\
\text { OBTENGARO DO } \\
\text { CREDITO \% }\end{array}$} \\
\hline & 1970 & 1975 & \\
\hline MA & 162,24 & 576,81 & 255,5 \\
\hline CE & 157,19 & 729,07 & 363,8 \\
\hline $\mathrm{RN}$ & 172,52 & $1.015,45$ & 488,7 \\
\hline PB & 236,56 & $1.003,52$ & 324,2 \\
\hline PE & 765,79 & $2.116,00$ & 176,5 \\
\hline AL & 858,50 & $3.028,59$ & 252,8 \\
\hline SE & 588,21 & $1.909,13$ & 224,6 \\
\hline BA & 362,72 & $1.161,07$ & 220,7 \\
\hline$M G$ & 883,88 & $2.245,09$ & 154,0 \\
\hline ES & 376,01 & $1.160,48$ & 212,8 \\
\hline RJ & $1.898,17$ & $3.423,87$ & 80,4 \\
\hline$S P$ & $2.613,13$ & $5.720,08$ & 118,9 \\
\hline PR & $1.322,86$ & $4.749,70$ & 259,0 \\
\hline SC & 539,54 & $2.252,11$ & 317,4 \\
\hline RS & $1.379,60$ & $4.334,53$ & 214,2 \\
\hline MT & 745,19 & $2.502,54$ & 235,8 \\
\hline GO & 795,42 & $2.226,73$ & 180,0 \\
\hline
\end{tabular}

Fonte: CONCRED - 6 VOLUMES

CENSOS AGROPECUARIOS 1970. - 1975

${ }^{1}$ Deflacionado com indice 2 da F.G.V. 
1970. Para o Nordeste podemos notar que os maiores crescimentos verificaram-se no Rio Grande do Norte, Cearā e Paraība (todos Estados com menos de $\operatorname{Cr} \$ 250,00$ de crédito por hectare em 1970) e é nestes Estados que observamos os maiores crescimentos (entre os Estados do Nordeste) na utilização de força mecânica, despesas em geral, da produtividade por hectare e no valor da produção.

Para o Sudeste, ē o Espĩrito Santo que tem o maior creşcimento do montante de crëdito por hectare. Appesar de neste Estado o progresso técnico assumir uma caracterîstica especĩfica (crescimento na utilização da arados animais), tambēm todos os outros itens da tecnificação sofreram incrementos durante o quinquēnio. Talvez o elemento mais significativo seja a prōpria concentração da posse da terra que neste Estado apresentou o segundo maior crescimento do paĩs.

Na região Sul o maior crescimento do crédito por hectare verificou-se em Santa Catarina, vindo o Paranā logo em seguida. Observamos a relação com a utilização de tecnologia, pois grande parte dos indicadores de progresso técnico nestes Estados apresentou os maiores crescimentos, o mesmo ocorrendo com o índice de Gini da distribuição da posse da terra do Paraná e de Santa Catarina. No Centro-Oeste, apesar da pequena diferença, o Mato Grosso apresenta um crescimento maior do crédito concedido, e percebemos que o crescimento da utilização de tēcnicas modernas no Mato Grosso è apenas um pouco maior do que o que se verificou em Goiās para alguns dos itens (despesas por hectare, utilização de adubos e tratores, decrescimento da utilização de arados de tração animal, crescimento da utilização de arados mecânicos, utilização de pessoal).

Mas apesar de notarmos que o crescimento da utilização de tecnologia estā associada ao crescimento do crédito agrīcola concedido, não podemos afirmar que o crescimento do crédito foi o' causador desta maior utilizaçãa de tecnologia. Pois hā outros fatores envolvidos na utilização de tecnologia, tais como as especifícicidades geogräficas, a concentração de posse, o tipo de cultura, eţc. Mas a observação de que os maiores crescimentos do crédito ocorreram exatamente nos Estados onde alguns dos indicadores de progresso tēcnico aumentaram mais, leva-nos a crer que esta relação è bastante importante. Por ou- 
tro lado, a maior concentração da posse da terra nestes mesmos Estados é uma importante mostra de que o crédito tem tido um papel importante neste aspecto da subordinação da agricultura.

E na utilização da tecnologia que observamas uma maior relação com o crēdito concedido. No Nordeste, os Estados mais tecnificados são Sergipe e Alagoas. O Estado de Sergipe tem os maiores niveis de utilização de arados mecânicos, tratores, adubos, enquanto Alagoas apresenta a segunda maior utilização de arados tráção animal, arados tração mecânica e tratores. Alagoas tambēm apresenta a maior utilização de força animal, os maiores valores em termos de despesa total , despesa com lavoura, despesa com salārios, o maior valor da produção e omaior rendimento por homem empregado. Estes estados, os mais tecnificados, foram os que obtiveram os maiores valores de crēdito rural por hẹ tare do Nordeste. Outro indicador que assume os maiores valores nestesdois estados é o preço da terra de lavoura.

No Sudeste, São Paulo assume uma posição de destaque,tan to em termos de crédito por hectare quanto do nĩvel de tecnificação. Ape sar do nĩvel de concentração da posse da terra em São Paulo ter caîdo no período, o Indice de Gini em São Paulo ainda è um dos mais altos das Re giões Sul e Sudeste.

Paranā, apōs o grande incremento de sua industrialização entre 1970 e 1975, passa a liderar quase todos os indicadores de modernização, e ē tambēm o segundo Estado logo apōs São Paulo em termos de montante de crédito por hectare de lavoura em 1975. Provavelmente o Paranā seja o melhor exemplo do processo de Modernização Conservadora, com um processo de industrialização intenso e com farta disponibilidade de recursos creditícios. Havendo aỉ tambēm um intensivo aumento de concentração da prophiedade da terra.

No Centro-0este observamos que o montante de crēdito concedido por hectare não é muito diferenciado entre os dois Estados e novamente observamos que os indicadores de utilização de tecnoloqia moderna apresentam níveis razoâveis para os cois Estados.

A partir deste estudo acerca dos maiores nīveis de obten- 
ção de crēdito e de tecnificação observamos que os Estados de Alágoas 'e Sergipe no Nordeste, São Paulo e Rio de Janeiro no Sudeste e Paranä e Rio Grande do Sui no Sul, apresentam os nĩveis mais altos de cada uma das regiões para os indicadores por hectare de: valor da produção agrîcola, produtividade da agropecuāria por homem empregado, preço da terra e crédito concedido.

Isto indica que hā forte relação entre a obtenção de crēdito, o valor da produção, a produtividade por homem empregado e o preço da terral. Elemento fundamental para se compreender o papel da política agrĩcola recente do estado brasileiro.

\subsubsection{0 Crēdito: 0 Crescimento dos Montantes}

A TABELA 3.4 mostra a evolução do crēdito rural em termos de seu valor absoluto, enquanto que as demais observações no presente trabalho procuram analisar a relação do crédito com outras variáveis a partir das alteraçōes que se dão a nĩvel da utilização por hectare. Uma anālise destes dados è pertinente, pois nem todas as grandes alterações podem ser captadas pelas anālises que consideram as váriações por hectare.

No Nordeste podemos observar que tanto o crédito total quanto o agrîcola tem seu maior crescimento nos Estados do Rio Grande do Norte, Maranhão, Alagoas e Ceará. Para os Estados do Maranhão e Cearā, como a expansão de ārea ē bastante acentuada, não hā um grande crescimento do crēdito por hectare ${ }^{2}$. Mas este crescimento do crédito parece afetar consideravelmente alguns indicadores de teenlficcação tais como a força mecânica utilizada, as despesas e alguns indicadores de produtividade. Estes indicadores sofreram nestes Estados um crescimento considerāvel, durante o perīodo em anālise. Para o Rio Grande do

${ }^{1} A$ relação entre crēdito e preço da terra serā objeto de estudo do proximo capĩtulo.

${ }^{2}$ Neste sentido enfatizamos novamente que o crēdito também se presta para a expansão das áreas da agricultura (Vide Tabela 2 do apêndice). 
JABELA 3.4 - Crédito Rural - Taxa Real de Crescimento Anual (Período 1969/76) - 17 Estados

\begin{tabular}{|c|c|c|c|}
\hline & $\begin{array}{c}\text { CREDITO RURAL } \\
\text { TOTAL }\end{array}$ & $\begin{array}{c}\text { CREDITO } \bar{A} \\
\text { AGRICULTURA } \\
\text { TOTAL: }\end{array}$ & $\begin{array}{l}\text { CREDITO PARA } \\
\text { INVEST IMENTIO }\end{array}$ \\
\hline MA & $30,65^{\mathrm{a}}$ & $27,95^{\mathrm{a}}$ & $47,06^{\mathrm{a}}$ \\
\hline PI & $27,40^{\mathrm{a}}$ & $23,56^{\mathrm{a}}$ & $26,14^{a}$ \\
\hline CE & $29,14^{\mathrm{a}}$ & $29,04^{a}$ & $24,54^{\mathrm{a}}$ \\
\hline RN & $32,19^{\mathrm{a}}$ & $32,99^{\mathrm{a}}$ & $31,09^{a}$ \\
\hline PB & $26,42^{\mathrm{a}}$ & $26,65^{a}$ & $24,35^{\mathrm{a}}$ \\
\hline $\mathrm{PE}$ & $19,76^{\mathrm{a}}$ & $20,19^{\mathrm{a}}$ & $26,63^{\mathrm{a}}$ \\
\hline$A L$ & $30,32^{\mathrm{a}}$ & $32,57^{\mathrm{a}}$ & $36,54^{\mathrm{a}}$ \\
\hline SE & $25,07^{\mathrm{a}}$ & $26,40^{\mathrm{a}}$ & $24,90^{\mathrm{a}}$ \\
\hline$B A$ & $29,39^{a}$ & $26,91^{a}$ & $33,71^{a}$ \\
\hline MG & $25,86^{\mathrm{a}}$ & $25,87^{\mathrm{a}}$ & $29,38^{\mathrm{a}}$ \\
\hline ES & $27,46^{\mathrm{a}}$ & $22,67^{\mathrm{a}}$ & $37.06^{\mathrm{a}}$ \\
\hline RJ & $14,57^{\mathrm{a}}$ & $11,40^{\mathrm{b}}$ & $26,05^{\mathrm{a}}$ \\
\hline$S P$ & $18,85^{\mathrm{a}}$ & $18,34^{\mathrm{a}}$ & $20,65^{\mathrm{a}}$ \\
\hline PR & $33,37^{\mathrm{a}}$ & $68,72^{\mathrm{a}}$ & $43,27^{\mathrm{a}}$ \\
\hline SC & $36,11^{\mathrm{a}}$ & $41,14^{\mathrm{a}}$ & $29,68^{\mathrm{a}}$ \\
\hline RS & $28,41^{a}$ & $58,75^{\mathrm{a}}$ & $22,05^{\mathrm{a}}$ \\
\hline MT & $41,42^{a}$ & $46,17^{\mathrm{a}}$ & $42,65^{\mathrm{a}}$ \\
\hline GO & $31,65^{\mathrm{a}}$ & $28,99^{\mathrm{a}}$ & $32,08^{\mathrm{a}}$ \\
\hline
\end{tabular}
(a) Significativo a $1 \%$
(b) Significativo a $5 \%$

Fonte: CONCRED - 1969/76 - M.A. 
Nộrte. e Alagoas hā também um crescimento significativo do crēdito por hectare; analisaremos suas consequências no pröximo item.

A parte do crēdito à agricultura que șe refere ao investimento (prazo de maturação do investimento é de no mînimo 5 anos) ${ }^{1}$ teve seu maior crescimento no Maranhão, o que pode parecer estranho dado o baixo grau de desenvolvimento do progresso técnico neste Estado. Mas o uso deste crédito esteve ligado à incorporação de novas āreas de cultivo (investimento em destoca e preparo do solo) e na compra de animais de trabalho. 0 total de investimentos em animais de trabalho (com ou sem crédi.to) soma aproximadamente $37 \%$ do total do crédito concedido no ano de 1975 neste Estado, segundo informação do Censo de 1975.

\subsubsection{A Grande Concentração do Crēdito Concedido}

As TABELAS 3.5, 3.6 e 3.7 apresentam algumas, evidēncias adicionais acerca da distribuição de crédito para os diversos Estados. Neste sentido, a partir de dados de crëdito rural total concedido à agropecuāria pelo Banco do Brasil (soma aproximadamente 68\% dos recursos do SNCR), podemos ter uma noção das diferenças na concentração em cada um dos Estados. Deve-se ter em mente que a participação do crēdito do Banco do Brasil ē maior nos Estados onde a participação dos bancos privados é menor, geralmente os Estados menos desenvolvidos. Nos Estados onde a integração entre o setor agrīcola e o financeiro è maior, os bancos privados participam mais intensamente na concessão de creditos e possivelmente beneficiam mais os grandes produtores.

A observação do T̄ndice de Gini (G) da TABELA 3.5 nos dā a indicação da grande concentração do crēdito rural. Mas devemos

\footnotetext{
IPara maiores detalhes vide CRIADORES Editora (1976)
} 
JABELA 3.5 - Distribuição do Crēdito Rural do Banco do Brasil no Brasil e em alguns Estados 1975² : Indice de Gini (G), indice de Theil ( $T$ ), porcentagem do crédito agrícola correspondente aos contratos menores do que a mediana (C50-)e aos maiores do que o 950 percentil ( $\mathrm{C} 5+1$, média (m) e a mediana: (D) em salārios mĩnimos.

\begin{tabular}{|c|c|c|c|c|c|c|c|}
\hline $\begin{array}{l}\text { ESTA- } \\
\text { DOS }\end{array}$ & $G$ & $\mathrm{~T}$ & C $50-$ & C. $5+$ & $\mathrm{Cl}+$ & $\mathrm{m}$ & $D$ \\
\hline MA & 0,585 & 0,696 & 12,2 & 49,4 & 25,8 & 36,4 & 17,5 \\
\hline$C E$ & 0,748 & 0,883 & 5,6 & 66,4 & 45,4 & 40,8 & 10,0 \\
\hline RN & 0,810 & 0,903 & 4,0 & 70,5 & 47,2 & $62 ; 9$ & 11,0 \\
\hline PB & 0,747 & 0,848 & 5,4 & 60,8 & 38,5 & $46 ; 9$ & 11,2 \\
\hline$P E$ & 0,852 & $0: 959$ & 3,1 & 74,5 & 56,3 & 100,8 & 13,6 \\
\hline$A L$ & 0,865 & 0,949 & 3,3 & 76,5 & 60,6 & 181,3 & 24,6 \\
\hline$B A$ & 0,751 & 0,764 & 4,9 & 49,2 & 26,7 & 134,5 & 28,5 \\
\hline$M G$ & 0,686 & 0,768 & 7,6 & 48,9 & 26,6 & 53,5 & 17,9 \\
\hline ES & 0,579 & 0,627 & 11,4 & 40,4 & 19,6 & 36,5 & 17,8 \\
\hline RJ & 0,775 & 0,910 & 5,7 & 66,2 & 49,5 & 70,6 & 17,4 \\
\hline$S P$ & 0,759 & 0,819 & $5,6$. & 55,7 & 34,6 & 128,6 & 31,6 \\
\hline$P R$ & 0,788 & 0,887 & 4,8 & 59,6 & 40,7 & 144,5 & 28,8 \\
\hline $\mathrm{SC}$ & 0,701 & 0,844 & 7,5 & 61,6 & 39,2 & 43,8 & 14,1 \\
\hline RS & 0,835 & 0,891 & 2,9 & 64,0 & 40,7 & 155,6 & 20,0 \\
\hline MT & 0,699 & 0,659 & 5,8 & 38,8 & 18,1 & 186,0 & 52,1 \\
\hline GO & 0,673 & 0,634 & 7,9 & 39,1 & 16,7 & 118,7 & 40,3 \\
\hline $\mathrm{BR}$ & 0,808 & 0,871 & 4,5 & 60,8 & 38,2 & 104,4 & - \\
\hline
\end{tabular}

${ }^{1}$ Não inclui Sergipe por não dispormos dos dados.

FONTE: Dados do Banco do Brasil. 
ter em mente que todas estas informações referem-se à distribuição entre os contratos que foram firmados pelos produtores que recebem crēdito. Podemos notar, a partir do indice de Gini, que os Estados que apresentam uma maior concentração na obtenção de crédito são Alagoas, Pernambuco, Rio Grande do Sul e Rio Grande do Norte. A observação dos dados do capítulo 2 que se referem à concentração da posse da terra, indicam semelhança quanto aos dois ỉndices, sendo a correlação entre os. mesmos igual a 0,25. Esta é uma constatação esperada visto que o crēdito é concedido tendo como garantia a propriedade da terra. A observação dos dados referentes à paríicipação dos 5\% maiores beneficiārios do crédito indica-nos que os Estados onde essa participação ē a maior são Alagoas, Pernambuco, Rio de Janeiro e Rio Grande do Norte.

Devemos ter em mente que são poucos os proprietärios que obtēm crédito. A TABELA 3.6 $6^{1}$ nos indica que em 1975 apenas 14,38\% dos estabelecimentos, no Brasil, obtinham crédito. Neste sentido, os indices de concentração da TABELA 3.5 apresentam uma distorção na medida em que consideram apenas a concentração entre os contratos assinados sem, levar em conta os estabelecimentos que obtiveram mais de um contrato ou aqueles que não obtiveram nenhum contrato.

Para sanar parte destes problemas, consideramos que cada contrato se refere a um estabelecimento e que os estabelecimentos que não obtém crédito (a partir dos dados de Censo) não tem contratos. Com este pressuposto e com a inclusão das propriedades que não obtēm crē-

IA TABELA 3.6 e oriunda dos Censos Agropecuārios. Hā, segundo alguns autores, uma subestimação no nūmero de estabelecimentos que obtém crédito. Isto porque geralmente os produtores declaram apenas o crédito de custeio como o crédito obtido, pois o crédito de comercializaçăo ē normalmente obtido pelos intermediārios e cooperativas. Em termos de comparaçäo entre os estados e entre 1970 e 1975 os dados são utilizāveis. 
TABELA 3.6 - Porcentagem de estabelecimentos que obtém crédito - 1970 1975

\begin{tabular}{|c|c|c|}
\hline & \multicolumn{2}{|c|}{$\begin{array}{cl}\text { PROPORÇAO DE } & \text { ESTABELECIMENTO } \\
\text { QUE OBTEM } & \text { CREDITO }\end{array}$} \\
\hline & 1970 & 1975 \\
\hline$M A$ & 1,41 & 2,51 \\
\hline CE & 9,13 & 12,25 \\
\hline RN & 7,66 & 11,81 \\
\hline PB & 7,65 & 9,81 \\
\hline$P E$ & 5,09 & 6,24 \\
\hline$A L$ & 5,23 & 6,33 \\
\hline$B A$ & 3,60 & 4,60 \\
\hline$M G$ & 15,45 & 19,87 \\
\hline ES & 12,25 & 19,91 \\
\hline RJ & 10,83 & 13,11 \\
\hline$S P$ & 22,72 & 31,89 \\
\hline PR & 15,26 & 20,56 \\
\hline SC & 21,63 & 30,45 \\
\hline RS & 21,28 & 31,43 \\
\hline MT & 19 & 11,28 \\
\hline GO & 14,03 & 19,77 \\
\hline BR & 11,53 & 14,38 \\
\hline
\end{tabular}

Fonte: CENSOS AGROPECUARIOS 1970 e 1975 
dito, no indice de Gini, obtivemos o indice de Gini corrigido $\left(G^{\prime}\right)^{1}$, a partir do qual pode-se realizar uma anāise mais realista da política de crēdito rural. Cabe frisar que esta medida, o indice de Gini corrigido do Crédito, tem a elevada correlação de 0,87 com o indice de Gini da concentração da posse da terra $(G)$. A partir da TABELA 3.7 podemos observar que hā uma grande concentração do crédito em todos os Estados e em muitos deles esta concentração atinge um nīvel quase absoluto (çasos de Alago:as:, Pernambuco e Maranhão). Por outro lado, os Estados onde essa concentração atinge nīveis mais baixos são aqueles onde a concentração da propriedade da terra tambēm è a menor (Santa Catarina e Espirito Santo).

Uma observação importante para a política de crēdito é que as correlações da TABELA 3,8 que relacionam grau de concentração de crēdito com nīvel tecnológico $\left(A_{1}\right)$, com montante de crédito concedido e com a produtividade por homem empregado são negativas. Isto é, hā indicações de que quanto mais concentrado è o crédito, menores serão os benefícios dele, isto $\bar{e}$, o nível da produtividade por homem empregado e o nível tecnológico. 0 fato de a maior concentração de crédito ter relação negativa com o montante de crēdito por hectare é bastante 10gico, 'pois com a concentração, menor nūmero de produtores recebem crēdito, fazendo com que a média (Crédito/ha) diminua.

Por outro lado, as correlações positivas e altas entre nível tecnológico, crédito por hectare e produtividade, atestam uma vez mais a relação entre essas variāveis. Ou seja, hā indicações de que quanto mais elevado è o montante de crédito concedido, mảis elevados são: o nīvel tecnolōgico e a produtịvidade por homem. Tambëm podemos constatar que o alto nível tecnolōgico se relaciona com a produtividade por homem empregado.

Constituem exceções os Estados de Santa Catarina e Espĩ rito Santo, que apesar de apresentàrem os mais baixos graus de concentração da obtenção de crēdito, obtēm relativamente baixos montantes de

10 Indice de Gini corrigido $\left(G^{\prime}\right)$ e dado por $G^{\prime}=S+G(1-S)$, onde $S$ è a proporção de propriedades que não obtêm crēdito. Maiores detalhes vide HOFFMANN (1971). 
TABELA 3.7 - Distribuição do Crēdito Rural do Banco do Brasil no Brasil e em alguns Estados para 1975: indice de Gini corrigido $\left(G^{\prime}\right)$ e indice de Theil corrigido $\left(T^{\prime}\right)$.

\begin{tabular}{|c|c|c|}
\hline ESTADOS & $G^{\prime}$ & $T^{\prime}$ \\
\hline MA & 0,990 & 0,992 \\
\hline$C E$ & 0,969 & 0,986 \\
\hline RN & 0,978 & 0,988 \\
\hline PB & 0,975 & 0,985 \\
\hline$P E$ & 0,991 & 0,997 \\
\hline$A L$ & 0,991 & 0,997 \\
\hline$B A$ & 0,988 & 0,989 \\
\hline$M G$ & 0,938 & 0,954 \\
\hline ES & 0,916 & 0,926 \\
\hline RJ & 0,970 & 0,988 \\
\hline$S P$ & 0,930 & 0,942 \\
\hline$P R$ & 0,956 & 0,977 \\
\hline SC & 0,909 & 0,952 \\
\hline $\mathrm{RS}$ & 0,948 & 0,966 \\
\hline MT & 0,966 & 0,961 \\
\hline GO & 0,935 & 0,928 \\
\hline$B R$ & 0,972 & 0,981 \\
\hline
\end{tabular}

Fonte: CĀLCULOS COM DADOS DO BANCO DO BRASIL E DOS CENSOS AGROPECUÄRIOS 
TABELA 3.8 - Correlações entre grau de concentração do crédito, os montantes de crédito por hectare, o nîvel tecnológico e a produtividade por homem ocupado - 16 Estados 1975

\begin{tabular}{|c|c|c|c|c|}
\hline & $\begin{array}{c}\text { GINI } \\
\text { CORRIGIDO }\end{array}$ & $\begin{array}{l}\text { CREDITO } \\
\text { POR } \\
\text { HECTARE }\end{array}$ & $\begin{array}{l}\text { NIVEL } \\
\text { TECNOLOTGICO } \\
\left(A_{1}\right)\end{array}$ & $\begin{array}{c}\text { PRODUT IV IDADE } \\
\text { POR } \\
\text { HOMEM }\end{array}$ \\
\hline Gini Corrigido & 1 & $-0,339$ & $-0,492$ & $-0,559$ \\
\hline Crédito por ha & & 1 & 0,866 & 0,815 \\
\hline $\begin{array}{l}\text { Nivel Tecnolo- } \\
\text { gico }\left(A_{1}\right)\end{array}$ & & & 1 & 0,781 \\
\hline $\begin{array}{l}\text { Produtividade } \\
\text { por homem }\end{array}$ & & . & & 1 \\
\hline
\end{tabular}


crédito por hectare. Is to significa que a tendência apontada pelas correlações advēm tanto de estados com al tas concentrações de crédito e de baixos montantes, quanto dos estados com relativamente baixas concentrações de obtenção de crēdito e grandes volumes de crēdito.

\subsubsection{O Direcionamento do Crédito para alguns produtos}

Além do aspecto da concentração do crédito rural por estabelecimentos, que agrava significativamente a di-stribuição da renda da popułação rural, observamos na TABELA 3.9 que hä tambēm concentração do crédito em alguns produtos.

0 arroz, a cana, a soja e o trigo obtēm proporção maior do crédito de custeios, do que geram em termos do Valor:Bruto da Produção para o ano de 1975. Is to significa que estes produtos para serem produzidos acabam por obter em termos de crédito uma parcela relativa maior do que geram de valor para o paīs. 0 café praticamente igual a percentual de crédito obtido como percentual dovalor gerado.

Mas os produtos como algodão, o feijão, a mandioca e 0 milho obtēm um percentual do crēdito menor do que seu percentual no va lor Bruto da Produção.

Podemos observar que os produtos mais típicos de pequena propriedadel e voltados para o abastecimento interno (feijão, mandioca e milho).tem menor participação no crédito do que no valor Bruto da Produção.

Enquanto os produtos de exportação ou ligados às agroindūstrias (café, soja e cana) estão entre os que obtém proporcionalmente mais crédito.

\footnotetext{
${ }^{I}$ Segundo GRAZIANO (1978) pg 179, 53,4\% do mi lho, 58,2\% do feijão, eram, em 1972, produzidos por estabelecimentos até 50ha. Pelos dados do Censo Agropecuärio de $1975,80 \%$ da mandioca foi colhida em estabelecimentos a te 50ha.
} 
TABELA 3.9 - Participação do crédito para certos produtos agrīcolas no total de crédito de custeio e participação do valor de produção desses mesmos produtos no valor bruto de produção total $19.75(\%)$

$\begin{array}{lrr}\text { Algodão } & 5,48 & 4,71 \\ \text { Arroz } & 12,07 & 17,56 \\ \text { Cafē } & 9,63 & 9,60 \\ \text { Cana } & 6,58 & 10,72 \\ \text { Feijão } & 6,61 & 1,40 \\ \text { Mandioca } & 8,25 & 0,41 \\ \text { Milho } & 12,73 & 10,75 \\ \text { Soja } & 13,52 & 17,39 \\ \begin{array}{l}\text { Trigo } \\ \text { Café + soja }+ \\ \text { cana + trigo }\end{array} & 3,30 & 12,44 \\ \begin{array}{l}\text { Feijão + man- } \\ \text { dioca + milho }\end{array} & 33,03 & 50,15 \\ \end{array}$

Fonte: MINISTERIO DA AGRICULTURA (CONCRED e SUPLAN) e BANCO CENTRAL DO BRASIL (dados primärios) in GUEDES PINTO (1980). 
A maior obtenção de crédito por alguns produtos reflete o maior incentivo do Estado aos mesmos. Neste sentido concluímos que os produtos voltados às agroindūstrias, de exportação ou de grandes e médios estabelecimentos, tem sido priorizados pela:política agrīcola.

\subsubsection{A Concentração Regional}

A concentração regional da polîtica de crēdito rural jā salientada no item 2.1.1 pode ser claramente observada na TABELA 3.10. A participação relativa da produção agrīcola no Norte e Nordeste $\bar{e}$ bastante maior que a participação destas duas regiões no crédito agrī:cola. Enquanto as régiões Sudeste, Sul e Centro-0este tem uma maior participação no crédito agrīcola do que suas produções na produção total.

TABELA 3.10 - Participação do Produto e do Crédito Agrīcola das regiões brasileiras no Produto Agrīcola Total e no Crédito Agrīcola Total 1975 - Porcentagem

\section{PRODUTO AGRICOLA CREDITO AGRICOLA}

\begin{tabular}{lcc}
\hline Norte & 2,30 & 0,99 \\
Nordeste & 22,41 & 11,28 \\
Sudeste & 28,34 & 33,33 \\
Sul & 40,17 & 46,07 \\
Centro-0este & 6,76 & 8,34 \\
\hline
\end{tabular}

Fonte: GUEDES PINTO (1980) 
Conclui-se daĩ que a polītica de crédito, espacialmente tem-se voltado para as regiões mais ricas do paĩs.

\subsection{Resumo do Capĩtulo}

- A política de crédito rural subsidiado tem sidoo principal instrumento de política agrícola nos anos recentes, tanto pelos grandes montantes concedidos quanto pela grande expansão do seu alcance.

- Esta política caracterizou-se durante a primeira metade da década de setenta por:

a) Grande crescimento dos montantes concedidos, chegando a $40 \%$ o crescimento anual em alguns estados.

b) Grande concentração do acesso ao crédito subsidiado.

c) Menor atendimento aos produtos ligados aos pequenos estabelecimentos e aos agricultores de abastecimento interno.

d) Grande concentração regional de sua destinação.

- Apesar de questionado por diversos autores, entendemos que o papel que o crédito subsidiado tem no sentido de elevar o nīvel de tecnificação da agricultura é inegāvel. Sem esta política, a modernização da agricultura brasileira, apesar de ainda pequena, não teria atingido nem sequer estes níveis. Inclusive a tecnificação de pequenas e médias produções sō parece ter sido possível dada a existéncia da política de crēdito subsidiado.

- A intensa concentração do crédito concedido parece dificultar a modernização da agricultura. Observamos que nos estados de maior concentração do crédito menores são os nĩveis de tecnificação e de produtividade por homem ocupado.

- 0 crédito rural subsidiado, pelas questões acima colocadas, acaba participando do ēxodo rural observado no perīodo. Como principal exemplo deste processo observamos o caso do estado do Paraná, onde a população rural decresceu entre os anos de 1970 e 1980.

- A política de crédito rural subsidiado, neste sentido, foi o principal instrumento de subordinação da agricultura ao capital, 
alēm de possibilitar a manutenção do pacto entre as burguesias industriais e financeiras e oligarquia agrāria. 
4. A QUESTAOO DA ELEVAÇAOO DO PREÇO DA TERRA

Um dos aspectos da subordinação da agricultura ao capital é a crescente mercantilização deste setor. Dentro desta mercantilização a terra passa a ser cada vez mais um elemento fundamental para a produção, posto que não ē um bem reprodutỉvel. Mas não ē apenas o fato de a terra ser umbem não repródutînel que determina a existência de um preço para ela. Este preço na realidade è composto de um grande número de relações que se estabelecem na economia, mas que se consolidam na renda que esta terra pode gerar.

Mas a elevação acentuada do preço da terra acarreta grandes alterações em toda economia e fundamentalmente no setor rural. Com a elevação acentuada do preço da terra observa-se a dificuldade de acesso a esta terra, a necessidade de uma produção ma is tecnificada (para os produtores que não haviam se tecnificado), a concentração da posse e a proletarização de parte dos pequenos produtores. Todos esses elementos participam do processo de subordinação da agricultura ao capital, dado que estas são condições necessárias à abertura de novas fronteiras de acumulação capitalista.

No Brasil, os dados disponiveis, referentes ao perīodo 1966 e 1978, apontam que a maior elevação dos preços de venda de terras deu-se durante os anos 70 a $75^{1}$.

1Vide PINHEIR E REYDON (1981). 
Neste perĩodo também verificaram-se as maiores transformações no uso de tecnologia moderna e uma política de crédito bastante generosa. Antes de adentrarmos nas relaçẽes entre o crédito, o nỉvel de tecnificação e o preço da terra, cabe uma discussão sobre os trabalhos de diversos autores que trataram do assunto.

\subsection{O preço da Terra: Algumas Anālises}

A anālise apresentada por SAYAD (1977) caracteriza a elevação do preço da terra pelo fato de o mercado de terra ser uma alternativa lucrativa de aplicações em relação ao investimento produtivo. Isto é, para ele o mercado financeiro não pode funcionar a contento principalmente porque os investidores tiveram preferência por "bens de raiz", e a existência de processos especulativos com a terra resultou na elevação de seu preço. Esta colocação se sustenta em uma anālise que se utiliza de um modelo para explicar o preço da terra em termos de reserva de valor. SAYAD coloca que "analisaremos um modelo onde a terra é considerada como uma reserva de valor alternativa ao capital produtivo. Consideramos a terra apenas como reserva de valor, e não como fator de produção, pois esta é a caracterīstica dos investimentos em imóveis que julgamos mais relevante". (SAYAD, 1977, p. 624).

A caracterî́stica bäsica do enfoque de SAYAD è que elevação excessiva do preço da terra nos ūitimos anos estā associada a um desarranjo no mercado financeiro, alēm de uma demanda acentuada por "bens de raîz". 0 fato de para SAYAD, haver substitutibilidade entre a aplicação em terras e aplicação no mercado financeiro faz com que as expectativas de ganhos futuros nesses dois tipos de aplicação determinam, em ūitima instância, a variação no preço da terra.

0 autor sugere que nos momentos em que o.mercado financei ro atuava com taxas de juros controladas e relativamente baixas, a opção seria o investimento em terras, acarretando a elevação em sua demanda, e consequentemente o seu preço elevar-se-ia acentuadamente. Is to basicamente ocorreu no periodo do "milagre", atë 1974. Sendo que no perīodo 
anterior e posterior ao "milagre" os preços não se elevaram tanto, dada a existēncia de taxas de juros não controladas.

Outros elementos que teriam participado dessa alteração na demanda, seriam o crédito seletivo para a agricultura, assim como a quebra do mercado de capitais (final de 1971)e os termos de troca agricultura/indūstria.

Neste sentido, a anālise de SAYAD, representa uma importante contribuição ao entendimento de um dos aspectos da elevação acentuada do preço da terra, as suas interrelações com os desarranjos dos mercados financeiros. Mas ao partir da visão de que a terra representa basicamente "reserva de valor", e que seu preço é determinado nos arranjos dos mercados, o autor acaba por não buscar as origens estrutu rais da acentuada elevação do preço da terra. Como consequência, SAYAD tambēm não coloca os efeitos dos processos de elevação do preço da terra, em termos da distribuição de riqueza, produção agrĩcola, concentração da posse da terra, etc.

Por outro lado, Ignācio Rangel em sua anālise traz uma importante contribuição ao estudo do papel desempenhado pela elevação do preço da terra nos aspectos mais globais do desenvolvimento recente da economia brasileira.

Para tanto, ele parte da visão de que a terra, por não ser produto de trabalho, não tem valor ${ }^{1}$, mas tem preço. Preço este advindo de renda que desta terra se pode auferir. E ele coloca que, a lém das rendas diferenciais (I e II) e de renda absoluta, temos a assim chamada 4a. renda, que seria a renda advinda da especulação em terras, ou seja, a valorização das terras dada basicamente pelo lado da demanda para fins não produtivos.

10 valor em termios marxistas, isto $\bar{e}$, o tempo de trabalho socialmente necessärito para a produçäo de uma mercadoria. 
Com 0 intuît to de buscar uma origem para a elevação recente do preço da terra, pela demanda não produtivã, Rangel coloca que "há uma relação inversa entre preço da terra e a taxa de lucros da economia, isto é, quando há uma "baixa conjuntura", o preço da terra deve se elevar. Mesmo que.o iucro da economia como um todo não caia, segundo o autor o preço da terra se elevará, pois há uma queda na taxa de juro.

Sendo que como conclusão bāsica. RANGEL coloca, 'de uma forma bastante semelhante a SAYAD, quezabase do problema do preço da terra é o mercado financeiro, que pelo fato de não funcionar a contento leva à aplicação de substancial montante de recursos na compra de terras, tendo sido este o mercado mais rentāvel em termos financeiros duran te o período 1970 a 1976.

Como consequencia, para o autor, a elevação acentuada do preço da terra fez com que o acesso de pequenos produtores a ela fosse dificultado tornando mais longinqua a idéia de uma terra bem distribuĩda. Ou como coloca RANGEL (1979 p. 190) "... o comportamento perverso do mecanismo de formação de preço da terra biloqueou eficazmente qualquer veleidade de reforma agräria, no sentido convencional de implantação de pequenas propriedades agrícolas (ou de solo urbano)...".

Sugere que com isto formou-se uma outra classe proprietāria, com fins apenas especulativos, que pode a qualquer momento entrar em algum tipo de conflito com o grupo latifundiārio propriamente dito.

Apesar de concordarmos com parte da anālise das consequēncias da acentuada elevação do preço da terra, nos parece importante frisar que no período maior de elevação do preço da terra, mesmo com taxas de juros relativamente baixas, as opções de investimento produtivo no setor urbano eram extraordinariamente boas. Is to é, 0 período 69/74 é marcado por taxas de crescimento da economia de até 13\%, que não criaria a necessidade da aplicação em bens com baixa liqquidez como a terra. Ainda mais quando observamos que o período de maior crescimento do preço da terra a nỉvel de Brasil é entre 1972 e 1975. 0 que levaria à grande aplicação em terras, acarretando sua elevação jā em 1972 e 1973? Talvez a queda nos preços da terra, apōs 1976, possa 
ser explicadas pela elevação da taxa de juro, ou pela queda na taxá de 1ucro, mas a elevação do preço da terra entre 1969 e 1975 tem outras causas mais especīficas do perīodo.

Um outro estudo, que não procura analisar as relações estruturais entre as variāveis, é de OLIVEIRA e COSTA (1978). Nește, atravēs da utilização de um modelo econométrico no qual hā o equilíbrio geral no mercado de terra agrīcola, tenta-se captar os principais fatores que participam da elevação do preço de terras, A conclusão bāsica à qual chega o estudo é que o ṕreço da terra se elevou dada a melhora na relação de trocas entre agricultura e indústria, sendo is to um subproduto inevitāvel da ação governamental. E coma colocam os autores "... deve-se esperar que toda polītica que eleve o valor da produtividade marginal da terra $(\ldots)$ determine um aumento ro aluguel desse fator" (OLIVEIRA e COSTA, 1978, pp. 149).

Neste sentido o estudo não procura abarcar a busca de explicações de problemas tais como o porque do preço da terra se elevar mais do que o arrendamento, ou que consequências adviriam desta elevação de preço.

WANDERLEY (1979), numa visão mais global, apresenta 0 preço da terra como determinado pela relação entre as diversas classes na divisão da renda gerada na economia. Para ela, dado que a terra é reserva de valor e seu preço normalmente tende a crescer, não hā necessidade do produtor incorporar no preço de sua produção o montante que seria destinado à renda desta terra. Isto porque na revenda da terra o produtor normalmente recupera pelo menos o montante que ele teria imobilizado na compra desta terra. Esta teria sido, para a autora, a forma que o capitalismo brasileiro encontrou para a manutenção do status-quo em termos da estrutura fundiāria. Mas mais do que isso Wanderley coloca que a terra tambēm se transformou em um poder de riqueza, levando atravēs de formas não produtivas (crédito, inflação) ganhos para este proprietārio.

REZENDE (:1981), por outro lado, coloca que a grande elevação do preço de vendas de terras agrīcolas se deve à política de crédito rural. A hipótese bāsica da qual parte o autor é de que o crédi- 
to subsidiado è um capital como outro qualquer. Isto é, é um capital que após obtido pode ser aplicado onde melhor convier ao beneficiārio da polïtica de crédito e passarā a fazer parte de seu capital. Neste sentido, para o autor, na realização da taxa média de lucro, por parte dos produtores, é imprescindīvel a obtenção do crédito rural subsidiado ${ }^{1}$. Portanto os produtores que não obtém o subsỉdio creditīcio não obtém a taxa média de lucro da economia.

Para ele, à medida que os subsīios dependem da posse da terra, a demanda por este bem vai se elevar, elevando seu preço. Neste sentido, para o autor, a elevação do preço da terra observado entre 1969 e 1973 é decorrência da política de crédito rural. Mas, por outro lado, REZENDE alerta para a questão de que a elevação acentuada do preço da terra deve ser analisada tambēm como fruto do próprio descenso cỉclico que se observa a partir de 1973. Isto, no sentido de que com as expectativas de baixos ganhos com a produção em geral, que proponderam a partir de 1973, os ganhos com terras passam a ser osmais rentavéis.

Jā em MARX (1975, p. 891) encontramos tentativas de explicação para este tipo de fenômeno. "No estudo que segue sobre o preço da terra abstraỉmos de todas as oscilações de concorrência, de todas as especulações e ainda da pequena propriedade fundiāria, quando a terra constitui o instrumento principal dos produtores, tendo eles por isso, de comprā-la a qualquer preço.

I - 0 preço da terra pode ascender, sem elevar-se a renda (1) por baixar simplesmente a taxa de juros o que faz vender-se a renda mais cara e por conseguinte aumentar a renda capitalizada, o preço da terra; (2) por subir o juro do capital incorporado ao solo.

$$
\text { II - } 0 \text { preço da terra pode elevar-se por aumentar }
$$

renda" 2 .

\footnotetext{
${ }^{i}$ Hā uma certa contradição na anāịise de REZENDE, pois em algumas passagens há a colocação de que o crédito é como um capital a maiș para os produtores, passando a ser um elemento constitutivo da taxa média de 1 ucro, enquanto em outras, para o autor este mesmo crédito è um lucro extraordinārio.

${ }^{2}$ Grifo do autor.
} 
İs to é, abstraindo as oscilações de concorrēncia e todaś as especulações pode haver elevação do preço da terra sem haver mudança

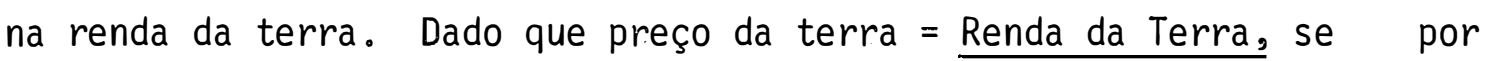
Juros

acaso o juro cai, a renda capitalizada aumenta, aumentando o preço da terra. Para MARX, dado que a renda da terra é, sob um prisma, como um retorno a um capital adiantando pelo proprietário, o arrendatário paga uma renda que sob a taxa de juro vigente, indica o preço da terra. Assim una queda na taxa de juro pode acarretar uma elevação do preço da terra. Por autro lado, o capital incorporado ao solo, em melhoramentos, investimentos, etc., tambëm participa do valor da renda. Se porventu ra 0 juro deste capital se eleva, dado a necessidade de manter o retornoao capital total adiantado,hā consequentemente uma elevação do preço da terra sem que varie a Renda da Terra.

E por ūltimo pode haver elevação da Renda da Terra, advinda da elevação da renda absoluta e/ou da renda diferencial. Por exemplo com uma elevação da produtividade de uma dada terra hă elevação da renda diferencial

Neste sentido, para MARX hā uma causação em termos da renda da terra para o preço, mas não necessariamente o inverso. Isto fica claro quando MARX (1975, pp. 895) coloca que "... do exposto se infere que a alta do preço da terra não acarreta necessariamente elevação da renda e que alta da renda, embora redunde sempre em elevação do preço da terra, não resulta necessariamente em alta dos produtos agrīcolas".

Portanto, a partir desta anālise nos parece claro que hā três grandes grupos de causas de elevação do preço da terra, que interagem. O primeiro seria atravēs da elevação da "Renda", isto é, elevação da produtividade; da urbanização, maior uso de tecnologia, etc. 0 segundo seria pela queda das taxas de juros, ou seja, o próprio mo- 
vimento cíclico da economia. Por ültimo teriamos os efeitos especulativos com terra que acarretariam uma elevação do seu preço.

4.2. 0 Crescimento do Preço da Terra no Brasil: uma contribuição

Neste item procuraremos mostrar como as alterações no preço da terra deram-se nos diversos Estados e que relações este preço guarda com as demais variāveis explicativas do preço em cada um dos Estados.

A TABELA 4.1 indica-nos que o crescimento do preço da terra foi bastante elevado para o período como um todo, mas concentrou-se mais nos Estadós do Sudeste, Centro-0este e Sul, e em alguns Estados do Nordeste. 0 maior crescimento foi observado no Estado do Espírito Santo; vindo logo a seguir Sergipe, Paranā, São Paulo e Alagoas. Mas os maiores preços da terra de lavoura em 1975 verificam-se, como podemos observar na TABELA 4.2, no Estado de São Paulo, vindo a seguir o Paranā e o Rio Grande do Sul.

Inicialmente devemos observar que o preço da terra elevou-se mais nos Estados onde houve um acentuado processo de tecnificação ou onde esta tecnificação tinha um nível mais elevado. A correlação entre a taxa de crescimento anual do nĩvel de tecnificação e capi talização e a taxa de crescimento do preço da terra é de 0,693, indicação da grande relação entre as duas variāveis. No nordeste, Alagoas e Sergipe estão entre os Estados que apresentam maiores crescimentos do preço da terra e é tambēm neles que observamos os maiores índices de valor da produção, das produtividades, da utilização de tēcnicas modernas, e de despesas de produção do Nordeste. Estes também são os Estados que obtém os maiores nîveis de crédito agrīcola por hectare na região.

Já na região Sudeste observamos que os maiores crescimentos em termos do preço da terra são observados no Espírito Santo e em São Paulo. O Espīrito Santo, apesar de ter um tipo de tecnificação mais atrasado (utilização de arados e de força animal), apresentou um crescimento substantivo na utilização de adubos e em despesas; mas foi entre os Estados do Sudeste, o que apresentou maior crescimento no crē- 
TABELA 4.1 - Taxas geométricas anuais médias de crescimento do preço real da terra de lavoura - 1969/1976 - 17 Estados $^{1}$

\begin{tabular}{lc}
\hline MA & $16,25^{\mathrm{a}}$ \\
CE & $7,54^{\mathrm{b}}$ \\
RN & $9,45^{\mathrm{a}}$ \\
PB & $14,97^{\mathrm{a}}$ \\
PE & $8,44^{\mathrm{C}}$ \\
AL & $28,72^{\mathrm{a}}$ \\
SE & $29,83^{\mathrm{a}}$ \\
BA & $19,11^{\mathrm{a}}$ \\
\hline MG & $25,70^{\mathrm{a}}$ \\
ES & $31,72^{\mathrm{a}}$ \\
RJ & $26,84^{\mathrm{a}}$ \\
SP & $29,43^{\mathrm{a}}$ \\
\hline PR & $29,65^{\mathrm{a}}$ \\
SC & $20,82^{\mathrm{a}}$ \\
RS & $28,33^{\mathrm{a}}$ \\
\hline MT & $27,13^{\mathrm{a}}$ \\
GO & $20,95^{\mathrm{a}}$ \\
\hline & \\
\hline & \\
\hline
\end{tabular}
a - significativo a $1 \%$
b - significativo a $5 \%$
c - significativo a $10 \%$

${ }^{1}$ Referente ao mês de dezembro, deflacionado pelo indice 2 de F.G.V. 
TABELA 4.2 - Preço real de venda da terra de lavoura ${ }^{3}$ - 17 Estados $1970 / 1975$ - Cr\$/ha de 1977

\begin{tabular}{|c|c|c|}
\hline & 1970 & 1975 \\
\hline MA & 315,94 & 537,94 \\
\hline$C E$ & 855,86 & $1.188,72$ \\
\hline RN & $1.129,32$ & $1.797,18$ \\
\hline PB & $1.753,78$ & $4.047,69$ \\
\hline$P E$ & $1.616,91$ & $2.848,89$ \\
\hline$A L$ & $1.274,52$ & $5.603,09$ \\
\hline SE & $1.322,91$ & $5.542,65$ \\
\hline$B A$ & $1.755,60$ & $4.549,36$ \\
\hline$M G$ & $2.344,95$ & $8.145,74$ \\
\hline ES & $2.455,30$ & $10.196,78$ \\
\hline RJ & $3.251,25$ & $10.313,64$ \\
\hline SP & $6.755,91$ & $25.990,62$ \\
\hline PR & $2.981,67$ & $13.406,32$ \\
\hline SC & $3.658,02$ & $10.507,06$ \\
\hline RS & $3.230,12$ & $11.611,16$ \\
\hline MT & $1.505,76$ & $5.732,04$ \\
\hline GO & $1.652,03$ & $5.190,06$ \\
\hline
\end{tabular}

Fonte: AGROPECUARIA - F.G.V.

Deflacionado pelo indice 2 da F.G.V. 
dito concedido por hectare. Jā São Paulo, alēm de apresentar o maior volume de crēdito por hectare, é o Estado mais tecnificado e que apresenta os maiores indices de produtividade tanto por hectare quanto por homem empregado.

Na região Sul, o Paranā surge como Estado de grande crescimento do preço da terra. E neste Estado tambēm que observamos os maiores indices de valor da produção e de produtividade e de diversas modalidades de tecnificação. Este Estado, além de ter os maiores īndices de tecnificação, apresentou os maiores crescimentos destes mesmos indices durante o perīodo 70/75. Um outro dado que observamos é que no Paraná é grande o montante de crédito por hectare. 0 Rio Grande do Sul, alēm de apresentar grande elevação do preço da terra, obteve grandes montantes de crédito e uma elevação significativa nos indices, de utilização de tēcnicas modernas.

Neste sentido, a partir das evidéncias acima, podemos colocar que a elevação acentuada do preço da terra estā intimamente 1jgada tanto ao uso de tecnologia quanto à concessão de crédito.

A TABELA 4.3 nos dā uma indicação da grande relação que hā entre a elevação do preço da terra e o crédito concedido durante o perīodo de 1969 a 1976. As correlações apresentam valores acima de $80 \%$ para todos os estados, exceto para Pernambuco e Maranhão, indi cando claramente a grande relação entre o crescimento do preço da terra e o crescimento da concessão de crédito.

Para melhor caracterizar as relações do crédito e de outras variāveis com o preço da terra, apresentamos no item seguinte um estudo econométrico.

\subsubsection{Um Estudo Econométrico para o Preço da Terra}

Neste item apresentaremos alguns resultados obtidos com a utilização de modelos econométricos, para explicar o preço da terra. As regressões visam captar os elementos que participam da formação do preço da terra da lavoura para o Brasil nos anos de 1970 e 1975 . As

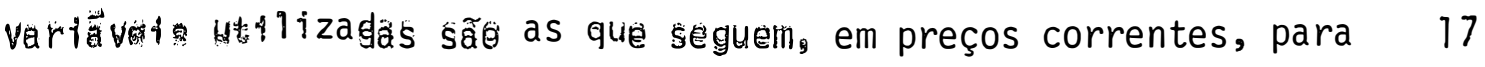


TABELA 4.3 - Equação de regressão do preço da terra de lavoura em função do crēdito rural total - Coeficiente de correlação, Coeficiente de regressão. 1969 - 1976

\begin{tabular}{ccc}
\hline ESTADO & CORRELAÇAO & $\begin{array}{c}\text { COEF ICIENTE DE } \\
\text { REGRESSÃA }\end{array}$ \\
\hline MG & 98,72 & $0,9624^{\mathrm{a}}$ \\
ES & 94,39 & $0,7824^{\mathrm{a}}$ \\
RJ & 97,45 & $0,5759^{\mathrm{a}}$ \\
SP & 98,34 & $0,6444^{\mathrm{a}}$ \\
\hline BA & 95,85 & $1,3056^{\mathrm{a}}$ \\
SE & 90,84 & $0,7753^{\mathrm{a}}$ \\
AL & 99,05 & $1,0382^{\mathrm{a}}$ \\
PE & 57,36 & $0,8511^{\mathrm{a}}$ \\
PB & 90,80 & $1,4669^{\mathrm{a}}$ \\
RN & 89,07 & $2,5080^{\mathrm{a}}$ \\
CE & 80,87 & $2,2374^{\mathrm{b}}$ \\
MA & 77,10 & $1,2184^{\mathrm{c}}$ \\
\hline MT & 89,62 & $1,1945^{\mathrm{a}}$ \\
GO & 93,21 & $1,2292^{\mathrm{a}}$ \\
\hline RS & 91,52 & $0,8866^{\mathrm{a}}$ \\
SC & 97,54 & $1,5200^{\mathrm{a}}$ \\
PR & 97,04 & $1,0289^{\mathrm{a}}$ \\
\hline
\end{tabular}

(a) Significativo a $1 \%$

(b) Significativo a $5 \%$

(c) Significativo a $10 \%$

OBS.: A equação foi ajustada aas logarítimos neperianos dos valores reais corrigidos pelo indice 2 da F.G.V. 
Éstados da Federação:

a) Variāvel Dependente:

Preço da Terra de Lavoura (PT), em cruzeiros por hectare.

b) Variāveis Independentes:

Nĩvel de Tecnificação e de Capitalização $\left(A_{1}\right)$ - Indice que indica a capitalização nos diversos Estados, obtido atravēs do método de componentes principais. (vide item 2.3.1.3).

Urbanização (URB) - Relação entre a população urbana e o total da população do estado.

Crēdito Agrīcola Total (CRE) - Crédito concedido pelas instituições financeiras oficiais e privadas à agricultura, em milhões de cruzeiros por hectare de lavoura.

Rentabilidade (RENT) - Diferença entre o valor da produção da agropecuāria e as despesas de produção dividida pela área total com agropecuāria ( $\mathrm{Cr} \$ / \mathrm{ha})$.

Preço de arrendamento (ARE) - Valor dos arrendamentos de terra agrīcola para lavoura (Cr\$/ha).

A função considerada é:

$\mathrm{PT}=F\left(A_{1 j}, \mathrm{URB}_{i}, \mathrm{CRE}_{i}, \mathrm{RENT}_{i}, \mathrm{ARE}_{i}\right)$ com $i=1, \ldots \ldots \ldots 17$

Inicialmente, podemos observar nos seis modelos de regressão da TABELA 4.4 um alto poder das variāveis para explicar o preço da terra $\left(R^{2}\right)$. Notamos também que o nível de capitalização $\left(A_{1}\right)$, sempre que aparece, tem um efeito estatisticamente significativo, indicando que tem uma participação efetiva na formação do preço da terra.

Observamos tambēm que quando o nīvel de capitalização $\left(A_{1}\right)$ não é incluīdo, o crédito agrícola passa a ter um efeito significativo, o mesmo ocorre com a rentabilidade da agricultura para o ano de 


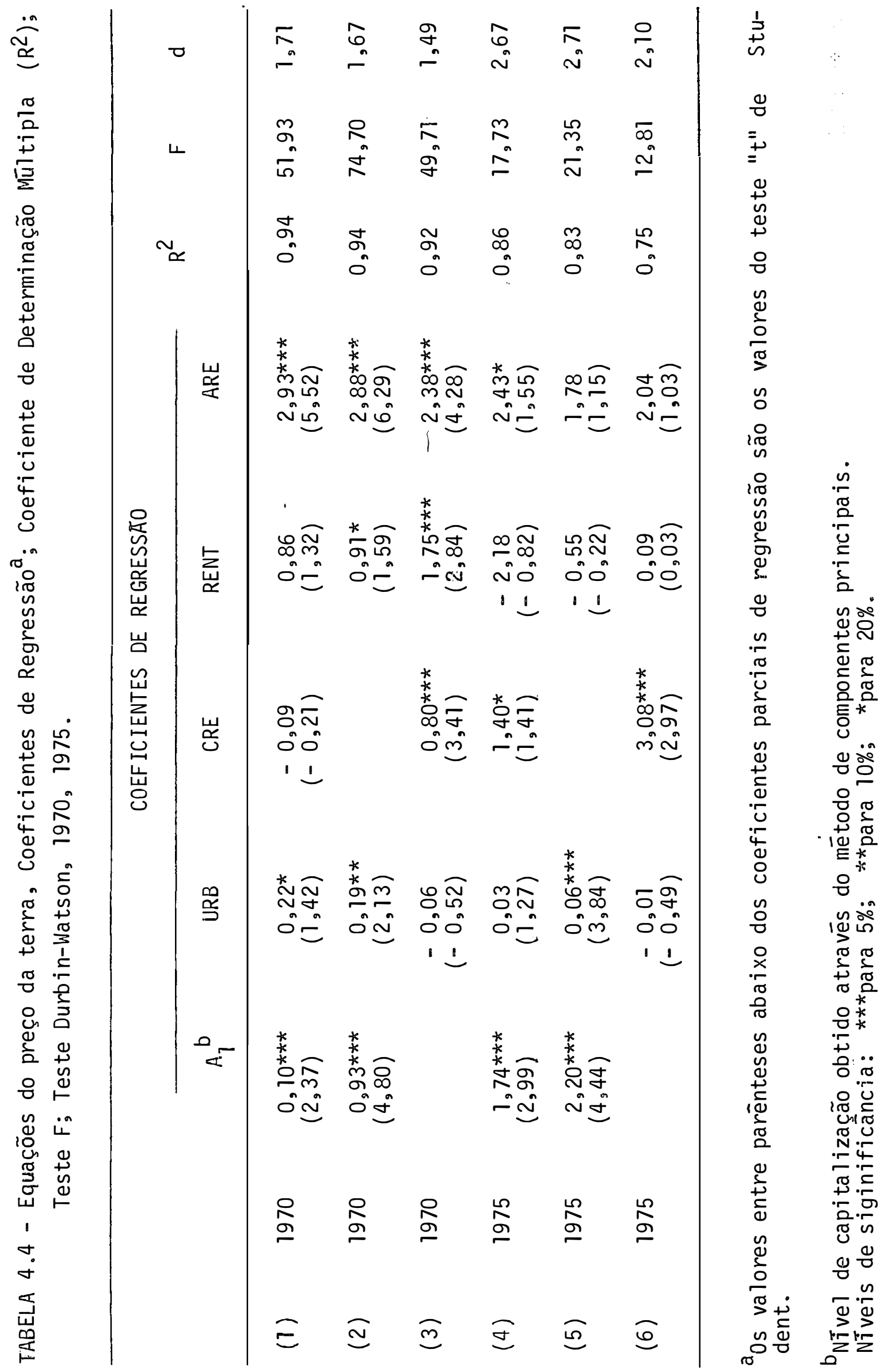


1970. Isto se deve ao fato de que a tecnificação ábsorve todo o poder explicativo que a rentabilidade e o crédito tem sobre o preço da terra, o que pode ser observado nas altas correlações em que hā entre o crēdito e $A_{1}$ na TABELA 4.5 .

TABELA 4.5 - Correlações entre nỉvel técnico e de capitalização com crédito por hectare, preço da terra, e rentabilidade de agropecuária por hectare - 1970 - 1975 - 17 estados.

Preços Correntes

\begin{tabular}{cccc}
\hline & CREDIT0 & $\begin{array}{c}\text { PRECO DA } \\
\text { TERRA }\end{array}$ & $\begin{array}{c}\text { RENTABILIDADE DA } \\
\text { AGROPECUARIA POR } \\
\text { HECTARE }\end{array}$ \\
\hline $\mathrm{A}_{1} 1970$ & 0,822 & 0,842 & 0,631 \\
$\mathrm{~A}_{1} 1975$ & 0,867 & 0,915 & 0,854 \\
\hline
\end{tabular}

Cabe observar também que as correlações tanto do crédito quanto do preço da terra com $A_{1}$ se elevam no perīodo. Isto é, há maior relação entre o nĩvel tecnológico e o preço da terra em 1975 que em 1970 .

Uma outra informação interessante refere-se ao ano de 1975, no qual se observa que nem o valor de arrendamento, nem a rentabilidade da agropecuária tem poder explicativo sobre o preço da terra. Basicamente são o crédito, o nỉvel de tecnificação e a urbanização que explicam este preço, mas com $R^{2}$ inferior ao observado nas equações referentes a 1970 .

Neste sentido, a partir destas regressões podemos concluir que entre 1970 e 1975 alteram-se os principais elementos na formação dos preços da terra. Em 1970 as cinco variāveis independentes participavam da formação do preço da terra, enquanto que em 1975 a rentabilidade e o valor de arrendamento perderam importância na determinação deste preço. 
tecnificação se elevar (como mostramos no capítulo.2); elevando o preço da terra, cresceu a importāncia de componentes especulativos na determinação do preço da terra.

A partir dos dados da TABELA 4.5, podemos tirar outras conclusões acerca deste processo. Inicialmente observamos que as correlações do crédito com o nîvel de capitalização e tecnificação $\left(A_{1}\right)_{2}$ além de serem relativamente elevadas, sofreram um crescimento entre 1970 e 1975, indicando que a relação entre elas se acentou. Embora a existência de correlação entre duas variāveis não prove que hā relação de causalidade, essas correlações indicam que o crédito desempenhou papel fundamental no processo de tecnificação da agricultura no período 1970-75.

Por outro lado, como se observa na TABELA 4.5, a rentabilidade da agropecuāria (RENT), a lém de apresentar correlações elevadas com o nỉvel de capitalização e tecnificação $\left(A_{1}\right)$, também teve estas correlações aumentadas neste quinquênio. Nas TABELAS 4.6 e 4.7 observa-se que entre as correlações com a rentabilidade, a que mais aumentou foi a com o crédito agrícola. Isso indica que hā uma maior relação entre o volume de crédito obtido pelos diversos Estados e a rentabilidade da agropecuāria destes mesmos Estados. Mas a correlação entre o preço da terra e a rentabilidade da agropecuāria decresceu, indicando que neste perīodo o preço da terra tem seu referencial com maior determinação em outro âmbito que não o produtivo.

E claro que o preço da terra não pode ser interpretado simplesmente como valor capitalizado dos preços de arrendamento. Verificamos que as correlações do arrendamento com quase todas as variáveis decresceu de valor, inclusive a com o preço da terra, no período em anālise. No nosso entender esta questão foi muito bem tratada por PINHEIRO (1980), que coloca que para o Brasil o preço de arrendamentos apenas em casos especīficos, onde o arrendamento é feito para produções tipicamente capitalistas, pode representar a renda da terra. Com isso não queremos apenas colocar que durante a conjuntura específica do inîcio dos anos 70 o arrendamento deixou de ser representativo do preço da terra, mas que o valor de arrendamento em si não coincide com a rendu da terre no Brasil. 
TABELA 4.6 - Correlações entre o crédito à agropecuāria, preço da terra de lavoura, rentabilidade da agropecuāria, preço de arrendamento e urbanização - 1970 - 17 Estados - Preços Correntes

\begin{tabular}{lccccc}
\hline & CREDITO & $\begin{array}{c}\text { PREÇO } \\
\text { DA } \\
\text { TERRA }\end{array}$ & $\begin{array}{c}\text { RENTA- } \\
\text { BILI- } \\
\text { DADE }\end{array}$ & $\begin{array}{c}\text { PRECO } \\
\text { ARRENDA- } \\
\text { MENTO }\end{array}$ & $\begin{array}{c}\text { URBA- } \\
\text { NIZA- } \\
\text { ÇAO }\end{array}$ \\
\hline Crëdito & 1 & 0,83 & 0,59 & 0,61 & 0,79 \\
Preço da Terra & 1 & 0,75 & 0,85 & 0,69 \\
Rentabilidade & & & 1 & 0,48 & 0,39 \\
Preço de Arrendam. & & & 1 & 0,45 \\
Urbanização & & & & 1 \\
\hline
\end{tabular}

TABELA 4.7 - Correlações entre crēdito, preço da terra, rentabilidade da agropecuāria, preço de arrendamento e urbanização - 1975 17 Estados - Preços Correntes

\begin{tabular}{lccccc}
\hline & CREDITO & $\begin{array}{c}\text { PREÇO } \\
\text { DA } \\
\text { TERRA }\end{array}$ & $\begin{array}{c}\text { RENTA- } \\
\text { BILI- } \\
\text { DADE }\end{array}$ & $\begin{array}{c}\text { PRECO } \\
\text { ARRENDA- } \\
\text { MENT0 }\end{array}$ & $\begin{array}{c}\text { URBA- } \\
\text { NIZA- } \\
\text { ÇÃO }\end{array}$ \\
\hline $\begin{array}{l}\text { Crédito } \\
\text { Preço da Terra }\end{array}$ & 1 & 0,85 & 0,72 & 0,08 & 0,55 \\
Rentabilidade & 1 & 0,68 & 0,34 & 0,63 \\
Preço de Arrendam. & & 1 & 0,31 & 0,25 \\
Urbanização & & & 1 & 0,22 \\
\hline
\end{tabular}


A elevação do preço da terra, além de estar ligada ao uso mais intensivo de técnicas (que dão uma expectativa de ganhos futuros elevados), teve componentes especulativos na sua formação entre 1970 e 1975.

0 fato de a rentabilidade da agropecuāria perder poder explicativo sobre o preço da terra em 1975 é um forte indicador do processo especulativo em curso. Mas este processo especulativo nunca está desligado do processo produtivo. Ou seja, se hā especulação com a terra, esta dar-se-ā nas terras onde há expectativa de elevados ganhos futuros. Ganhos futuros que são possîveis tanto com a produção quanto com rendas não produtivas que são auferidas com a propriedade da terra. Estas rendas abrangem desde o subsīdio do crédito, a possibilidade de ganhos não produtivos com o crédito, até os incentivos fiscais.

Como jā apontamos anteriormente, hā grande relação entre o crédito concedido e o preço da terra; as regressões da TABELA 4.3 deram-nos indicações de quão forte era esta relação. Claro que nestas regressões estão embutidos os componentes de tecnificação que 0 crédito possibilita e que elevam o preço da terra. As regressões da TABELA 4.4 dão uma amostra de quão significativo é o nĩvel de tecnificação para o preço da terra, mas no sentido de que esta tecnificação indica um ganho futuro mais elevado.

Mas o fato de que para a regressão de 1975 o crédito é significativo mesmo quando incluî̉da a tecnificação, é uma indicação de que o preço da terra também é diretamente afetado pelo crédito.

Cabe explicar como este crédito eleva o preço da terra pela via especulativa ${ }^{1}$. Na medida em que a utilização do crédito não é fiscalizado, sua distribuição é relativamente farta entre os grandes produtores e sua aplicação em outros setores é rentável, seu desvio ē inevitāve1. O fato de que hä setores mais rentáveis fica bastante 
agravado quando observamos que a partir de 1973 hā o que os economistas chamam de "Ciranda Financeira", que è uma grande especulação no mercado financeiro bancado pelo governo, dada a desestruturação des te mercado. E é exatamente nos anos 1973, 1974 e 1975 que mais se elevam os preços da terra e a concessão de crédito agrīcola.

Queremos destacar que a desestruturação do mercado de capitais não ē a principal causa da elevação do preço da terra, pois esta desestruturação se dā em 1971, e è a partir de 1973 que o preço da terra começa a sofrer sua maior elevaçãol. Deve-se assinalar, entretanto, que a desestruturação do mercado de capitais em 1971 certamente tem algum efeito no sentido de elevar o preço da terra, mas não ē 0 principal componente explicativo.

Mas a elevação do preço da terra pela via especulativa, que o crédito possibilita, se dá na medida em que a terra é a garantia para a obtenção do crēdito, e a prōpria possibilidade de ganhos com essa terra, via o desvio do crédito, é bastante atraente. Ganho este que se incorpora $\bar{a}$ assim chamada renda da terra e que passa a compor o preço da terra.

Para uma observação mais detalhada da relação entre 0 crédito e o preço da terra apresentamos a TABELA 1 e 4 do APENDICE onde observamos que nos Estados onde. o preço da terra mais se elevou (Espĩrito Santo, Sergipe, Paranā, São Paulo, Alagoas), hā uma grande relação entre as taxas de crescimento do crédito concedido e do preço da terra, principalmente no periodo 1972 a 1975. Observamos que mesmo nos Estados onde o crescimento do preço da terra apesar de grande, e menor que nos cinco Estados acima, hä crescimento significativo do crédito total concedido no perỉodo de 72 a 75 .

Para a observação da existência de causalidade entre 0 crédito concedido e o preço da terra há também os grāficos que constam do APENDICE. A partir deste gráficos podemos constatar que tanto em Alagoas quanto em São Paulo todo crescimento do crédito representou

IVide TABELAS 1 e 3 do Apểndice. 
um crescimento do preço da terra. Apenas no ano de 1976 o decréscimó do crédito concedido em Alagoas representou uma queda no preço da terra, enquanto em São Paulo o decréscimo do crédito não impediu que o preço da terra crescesse, embora menos intensamente que no ano anterior.

\subsubsection{Algumas Conclusões acerca do Comportamento do Preço da Terra}

- 0 preço de venda de terra de lavoura cresceu mais nos estados onde o nīvel de tecnificação era maior ou onde mais se elevou.

- Tambēm hā relação entre a elevação do preço da terra e os montantes de crédito concedido.

- 0 estudo economētrico do preço da terra nos indicaque:

a) 0 preço da terra tem sido bastante influenciado pe10 nîvel de tecnificação da agricultura.

b) Elementos especulativos passam a ter maior participação em 1975 da formação do preço da terra do que em 1970.

c) 0 crédito subsidiado tem uma elevada participação na formação do preço da terra em 1975, inciusive quando se exclue a sua participação na tecnificação.

- Concluimos que apesar da elevação do nĩvel tecnolōgico, e da elevação de sua influêncja sobre o preço da terra, os elementos não produtivos (especulativos) apresentaram um maior crescimento no perīodo. Elementos especulativos estes, provavelmente advindos da própria política creditīcia, que possibilitam ganhos não produtivos elevados, mas extremamente dependentes da propriedade territorial.

- A acentuada elevação do preço da terra observada no perỉodo estudado tem grande participação no processo de subordinação da. agricultura. A terra ao ter acentuada sua caracterīstica de um bem mer cantil de alta lucratividade acaba por impossibilitar o acesso a ela de qualquer forma de produção que não tenha um elevado grau de capitalização. Neste sentido, a produção agrĩcola necessita crescen temente estar ligada às formas de exploração que viabilizant uń àle vetórno, e isto implica em uma produção 
altamente subordinada aos demais setores da economia. 


\section{CONSIDERAÇOES FINAIS}

Neste item procuraremos descrever o caminho que percorremos, lançando mão de diversas hipōteses, que muitas vezes não puderam ser testadas e merecem outros estudos, para tentar analisar o papel da política de crédito rural noprocessode subordinação da agricultura brasileira ao capital.

A hipōtese básica deste trabalho è que o crédito rural foi, durante a primeira metade da década de 70 , o principal instrumento de subordinação da agricultura ao capital. Isto é, o crédi.to teria viabilizado na agricultura um novo espaço de atuação e de valorização de capital. Para tanto, inicialmente coube observar que o crédito rural foi o mais importante fator de transformação da agricultura brasileira.

As transformações na agricultura foram bastante intensas durante o período, desde o aumento da produtividade do trabalho e da terra agrīcola de produtos de exportação, em algumas regiões, passando pelo aumento do grau de concentração fundiāria em alguns estados e pela elevação do preço da terra, atē o aumento da tecnificação de uma forma mais geral.

A partir destas constatações podemos aventar a hipōtese de que a industrialização da agricultura brasileira parece ter se pautado peỉa elevação da produtividade por homem ocupado e, consequentemente, pela elevação dos lucros na agricultura, mantendo a ênfase nas expor- taçểes agrïcolas. Visou a subordinação da agricultura, na medida em que 
possibilitou novo campo de aplicação de capitais.

As inūmeras informações ao longo do trabalho

(TABELA

4.5), que mostram a elevada relação entre o crédito rural e o nīvel tecnológico e de capitalização, e o crescimento desta relação, aliado ao fato de que a maior concessão de crédito e a maior tecnificação se deram no perīodo 1970/1975; evidenciam a importância que esta política teve para o processo de modernização.

Os pacotes tecnológicos acoplados aos financiamentos do S.N.C.R. (Serviço Nacional de Crédito Rural) são mais uma evidência da importância que o crédito rural assumiu no processo de modernização da agricultura brasileira:

Hā indicações, que merecem mais estudo, de que os agricultores tornaram-se extremamente dependentes do crédito rural, tanto para o plantio e investimento quanto para o custeio agrícola, tornandose mais vulnerāveis às mudanças da polītica de crédito rural, o que não deixa de ser uma forma de subordinação da agricultura ao processo de acumulação de capital.

Caberia ressaltar que o processo de Modernização se deu de formas bastante dispares, nos diversos estados brasileiros, o que mereceria estudos especīficos mais aprofundados. 0 prōprio processo de concentração fundiāria, não observado em todos os Estados, durante o período, possivelmente em decorrência de fatores históricos e polīticos de cada Estado ou região, è um importante assunto a ser mais profundamente analisado.

Hā algumas evidencias de que a modernização da agricultura brasileira se fez mais presente entre os grandes e médios estabelecimentos, mas com alguma importância também entre os pequenos estabeTecimentos. Acerca disto levantou-se a hipótese de que a tecnologia disponīvel não é prōpria a pequenos estabelecimentos e que os altos custos desta tecnologia dificultam o acesso dos menores estabelecimentos a esta tecnologia, mesmo porque a obtenção de crédito pelos pequenos agricultores e bastante reduzida. 
Outra questão, que apesar de ser decorrēncia lōgic a da. anālise, mas não pode ser comprovada, é a importância que o setor rural passou a ter para o setor industrial em termos de consumo de tecnologia e de insumos, o que nos leva a levantar a hipōtese de que um dos principais fatores que levaram a este tipo de modernização da agricultura brasileira tenha sido a necessidade da indústria de insumos no Brasil de ocupar novos espaços de realização de sua produção. Esta seria uma das formas mais importantes de subordinação da agricultura ao capital, isto $\bar{e}$, a agricultura passa a ter suas transformações, como um todo, determinadas em outras esferas.

Por outro lado, há evidēncias de que a polītica de credito no Brasil; no inīcio da década de 70, afetou a agricultura, num de seus pontos mais importantes: o preço da terra.

A acentuada elevação do preço da terra, no nosso entender, foi decorrente tanto da elevação dos ganhos produtivos com a terra, advindos da elevação da utilização de tecnologia, possīvel com a polītica de crédito, quanto da elevação dos ganhos especulativos advindos da propriedade da terra.

Quanto aos ganhos especulativos, estes podem advir do aumento da demanda por terras, decorrente da prōpria polītica de crédito. Por um lado a prōpria propriedade da terra, na medida que è uma condição necessāria para a obtenção de crédito, passa a ser um bem extremamente atrativo. Por outro lado, o próprio crédito ao ser um recurso não fisca lizado pode ser utilizado para compra de terras, elevando a demanda por este bem.

A acentuada elevação do preço da terra acabou por dificultar o acesso a ela, de produtores sem grandes capitais, e por outro lado, possibllitou ganhos não produtivos a inūmeros proprietários. Elementos estes que indicam que a agricultura, tambēm por este aspecto, tenhà se tornado mais subordinada ao capital.

Neste sentido, a "Modernização Conservadora", implementada no Brasil a partir do inīcio dos anos 70, apesar de revolucionária, dadas as transformações dela decorrentes, se iniciou sem grandes transformações estruturais da agricultura. Hā indicações de que suas conśéquëncias vão desde a formação de um proletariado rural, com a 
expulsão de inümeros pequenos agricultores, subordinando outros, chegando atē a subordinação mais geral da agricul tura ao capital.

Se não pudemos provar parte do que colocamos, pelo mesnos gostariamos de que este estudo seja uma primeira análise de alguns pontos que entendemos serem de suma importância para os estudiosos do meio rural. Ou seja, uma anālise que procura observar na estrutura ou na base da agricultura, os principais mecanismos de sua transformação. 
BIBLIOGRAFIA

BRASIL. Fundação Instituto Brasileiro de Geografia e Estatīstica, 1975. Censo Agropecuário de 1970 - Brasil. Rio de Janeiro.

BRASIL. Fundação Instituto Brasileiro de Geografia e Estatĩstica, 1979. Censo Agropecuário de 1975 - Brasil. Rio de Janeiro.

CASTRO, A. e outros, 1979. Evolução Recente e Situação Atual da Agricultura Brasileira. Rio de Janeiro, Binagri Ed.

CONTADOR, C.R., 1975. Tecnologia e Desenvolvimento Agrīcola. Rio de Janeiro (Série IPEA/INPES nọ 17).

EDITORA DOS CRIADORES - 1976. Crēdito Rural. São Paulo, Editora dos Criadores.

FUNDAÇAO GETULIO VARGAS, Rio de Janeiro, 1979. Agropecuāria-Preços Mēdios e Indices de: Arrendamentos, Vendas de Terra, Salärios de 1966 a 1978. (Centro de Estudos Agrícolas - IBRE).

FUNDAÇAO GETULIO, Rio de Janeiro, vārios anos. Conjuntura Econōmica.

GRAZIANO DA SILVA, J.F., Coord., 1978. Estrutura Agrāria e Produção de Subsistencia na Agricultura Brasileira. São Paulo, Hucitec. 
GRAZIANO DA SILVA, J.F., 1980. Progresso Técnico e Relações de traba Tho na Agricultura Paulista. Campinas, UNICAMP (Tese de Doutoramento).

GRAZIANO DA SILVA, J. F., 1930b. A Pequena Produção e as Transformações da Agricultura Brasileira. In: Cadernos CEAS. Salvador, 69:56-67.

GRAZIANO DA SILVA, J. F., e HOFFMANN, R. 1980. A Reconcentração Fundiāria. In: Reforma Agrāria, Campinas, ano X, nọ 06. (Boletim da Associação Brasileira de Reforma Agrāria).

GRAZIANO DA SILVA, J. F., coord., 1981. A Modernização da Agricultura e as alterações nas Relações de Trabalho. Campinas, UNICAMP/FINEP (mimeo).

GRAZIANO DA SILVA, J: e KAGEYAMA, A.1983. Emprego e Relações de Trabalho na Agricultura Brasileira: Uma anālise dos dados censitārios de 1960, 1970 e 1975. In: Pesquisa e Planejamento Econômico, IPEA, vol. 13, 1:235.266.

GUEDES PINT0, L. C., 1979. Notas sobre a Polĩtica Agrỉcola Brasileira. In: Encontres com a Civilização Brasileira. Rio de Janeiro, Ed. Civilização Brasileira, 7:193-206.

GUEDES PINTO, L. C., 1980. Notas sobre Polïtica Agrīcola e Crēdito Rural. Campinas, UNICAMP (mimeo).

GuiprarAES, A. P., 1979. A Crise Agrāria. Rio de Janeiro, Edi tora Paz e Terra.

HOFFMANN, R., 1971. Contribuição à. Anālise da Distribuição da Renda e da Posse da Terra no Brasil. Piracicaba, ESALQ/USP (Tese de Livre Docência).

HOFFMANN, R., 1979. Anālise de Regressão: Uma introdução à Econometria. São Paulo, Hucitec.

HOFFMANN, R., 1979. A Concentração da Posse da Terra no Brasil. In: Encontros com a Civilização Brasileira. Rio de Janeiro, Ed. Civilização Brasileira, 7:207-2.21. 
INCRA/UNICAMP, Campinas, 1978. Comercialização e Formação de Preços: vol. I (mimeo).

KAGEYAMA, A e GRAZIANO DA SILVA, J., 1983. Os resultados da Modernização Agrīcola nos anos 70. In: Revista de Estudos Econômicos, IPE, vor. 13, 3:537-559.

LENIN, V. I., 1979. El Dessarollo del Capitalismo en la Rüssia. Buenos Aires, Ed. Estudio.

LENIN, V. I., 1980. Capitalismo e Agricultura dos E.U.A. São Paulo, Ed. Debates.

LOUREIRO, M.R.G., Org., 1981. Cooperativas Agrícolas e Capitalismo no Brasil. São Paulo, Cortez Autores Associados.

MARX, K., 1974. O Capital. Rio de Janeiro, Ed. Civilização Brasileira, livro 3 , vol. 6 .

MELLO, J.M.C., 1975. O Capitalismo'Tardio. Campinas, UNICAMP.(Tese de Douitoramento).

MEDONÇA DE BARROS, J e GRAHMAN, D. H., 1978: A Agricul tura Brasileira e o Problema da Produção de Alimentos. In: Pesquisa e Planejamento Econômico, IPEA, vol. 8, $\underline{3}: 695-725$.

MOORE, B., 1968. As origens Sociais da Ditadura e da Democracia. Lisboa, Edicões Cosmos

MORRISON, D. F., 1976. Multivariate Statistical Methods, U.S.A., MC Graw - Hill Book Company.

OLIVEIRA, J. T. e COSTA, I.D.N. da, 1978. Evolução do Preço da Terra no Brasil - 1966/1974. In: Revista Econömica do Nordeste. Salvador, vol.9, no 2, abr./jun. 1978, p.149-174.

PAIVA, R. M, Coórd: 1976. Setor Agrīcola do Brasil. Rio de Janeiro,

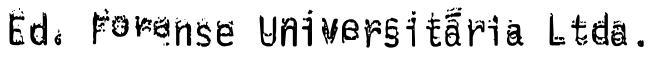


PINHEIRO, F. A., 1980. Renda e o Preço da Terra: Uma contribuição à Anālise da Questão Agrāria Brasileirra. Piracicaba, (Tese de Livre Docência).

PINHEIRO, F. A. e REYDON, B. P., 1981. O Preço da Terra e a Questão Agrāria - Algumas Evidências Empīricas. In: Revista de Economia Rural, Brasileira, SOBER, vol.19, no 1, jan./mar. 1981, p. 5 - 15.

RANGEL, I. M., 1977. Questão Agräria e Agricultura. In: Encontros com a Civilização Brasileira. Rio de Janeiro, Ed. Civiliz. Bras, nọ 7 (janeiro de 1977) p. 172 a 192.

REG0, A. C., 1980. Crédito Rural no Brasil: Uma Contribuição à Anālise. da Distribuição. Brasīlia, UnB (Tese de Mestrado).

REZENDE, G. C., 1981a. Polītica de Crēdito e sua Eficácia. In: Conjuntura Econômica. Ri.o de Janeiro, FG. , vol. 35, no 5, maio, p. 99 a 90.

REZENDE, G. C., 1981b. Crédito Rural Subsidiado e Preço da Terra no Brasil. In: Textos para Discussão Interna, INPES/IPEA, nọ 41, dezembro de 1981.

RIBEIRO, D., 1979. Crédito Rural no Brasil: Avaliação e Altternativas. São Paulo, Ed. Unidas.

RYFF, T., 1978. Por que è tão cara a terra? In: Jornal do Brasil, 2/4/78.

SANDRONI, P., 1980. Questão Agrāria e Campesinato, São Paulo, Edittora Polis.

SAYAD, J., 1976. Crédito Rural no Brasi1: Avaliação e Crīticas. In: FIPE - Ministério da Agricultura - fevereiro de 1976, relatōrio de pesquisa.

SAYAD, J., 1977. Preço da Terra e Mercados Financeiros. In: Pesquisa e Plánejamento Econômico, Rio de Janeiro, $\underline{7}(3): 623-62$ (dez.). 
SAYAD., J., 1977. Planejamento, Crēdito e Distribuição de Renda. In: Revista de Estudos Económicos. São Paulo, FIPE, v̀ol. 7, nọ 1.

SILVA, S. S., 1979. Formas de Acumulação e Desenvolvimento do Capitalisno Campo. In: PINSKY, J., Coord. Capital e Trabalho no Campo. São Paulo, Hücitec.

SILVA, S. S., 1981. Valor e Renda da Terra (0 Movimento do Capital no Campo). São Paulo, Polis.

SORJ, B., 1980. Estado e Classes. Socia is na Agricultura Brasileira. Rio de Janeiro, Zahar Editores.

TIKHONOV, V. 1978. On The Industrialization of Agriculture. In: Probiems of Economics. New York, 52(21):3-22/jun. 1978.

WANDERLEY, M.N.B., 1979. Capital e Propriedade Fundiāria na Agricultura Brasileira. In: ARAUJO, J. B., coord. Reflexões sobre a Agricultura. Brasileira. Rio de Janeiro, Ed. Paz e Terra. 
APẼNDICE

TABELA 1 - Preço da terra de lavoura - 17 Estados. dez. $69=100$

\begin{tabular}{ccccccc}
\hline & \multicolumn{2}{c}{ MARANHAO } & \multicolumn{2}{c}{ CEARA } & \multicolumn{2}{c}{ RIO GRANDE } \\
\cline { 2 - 7 } & $\begin{array}{c}\text { INDICE } \\
\text { REAL }\end{array}$ & $\begin{array}{c}\text { TAXA DE } \\
\text { CRESC。 }\end{array}$ & $\begin{array}{c}\text { INDICE } \\
\text { REAL. }\end{array}$ & $\begin{array}{l}\text { TAXA DE } \\
\text { CRESC. }\end{array}$ & $\begin{array}{c}\text { INDICE } \\
\text { REAL }\end{array}$ & $\begin{array}{c}\text { TAXA DE } \\
\text { CRESC. }\end{array}$ \\
\hline 69 & 100 & 0 & 100 & 0 & 100 & 0 \\
70 & 173 & 78 & 86 & -13 & 92 & -7 \\
71 & 213 & 22 & 80 & -7 & 89 & -3 \\
72 & 342 & 56 & 85 & 6 & 89 & -0 \\
73 & 271 & -20 & 91 & 7 & 108 & 21 \\
74 & 301 & 10 & 111 & 21 & 125 & 15 \\
75 & 304 & 0 & 120 & 8 & 147 & 17 \\
76 & 366 & 20 & 161 & 34 & 177 & 20 \\
\hline
\end{tabular}

\begin{tabular}{ccccccc}
\hline & \multicolumn{2}{c}{ PARAIBA } & \multicolumn{2}{c}{ PERNAMBUCO } & \multicolumn{2}{c}{ ALAGOAS } \\
\cline { 2 - 7 } & $\begin{array}{c}\text { INDICE } \\
\text { REAL }\end{array}$ & $\begin{array}{c}\text { TAXA DE } \\
\text { CRESC. }\end{array}$ & $\begin{array}{c}\text { INDICE } \\
\text { REAL }\end{array}$ & $\begin{array}{c}\text { TAXA DE } \\
\text { CRESC. }\end{array}$ & $\begin{array}{c}\text { INDICE } \\
\text { REAL }\end{array}$ & $\begin{array}{c}\text { TAXA DE } \\
\text { CRESC. }\end{array}$ \\
\hline 69 & 100 & 0 & 100 & 0 & 100 & 0 \\
70 & 96 & -3 & 83 & -16 & 108 & 8 \\
71 & 90 & -7 & 82 & -1 & 111 & 3 \\
72 & 90 & 0 & 64 & -21 & 143 & 28 \\
73 & 125 & 39 & 80 & 23 & 175 & 22 \\
74 & 166 & 32 & 135 & 68 & 336 & 92 \\
75 & 224 & 34 & 147 & 8 & 477 & 41 \\
76 & 207 & -7 & 137 & -6 & 435 & -8 \\
\hline
\end{tabular}


TABELA 1 - Continuação - Preço da terra de 1avoura - 17 Estados.dez. 69 $=100$

\begin{tabular}{rrrrrrr}
\hline & \multicolumn{2}{c}{ SERGIPE } & \multicolumn{2}{c}{ BAHIA } & \multicolumn{2}{c}{ MINAS GERAIS } \\
\cline { 2 - 7 } & $\begin{array}{c}\text { INDICE } \\
\text { REAL }\end{array}$ & $\begin{array}{c}\text { TAXA DE } \\
\text { CRESC. }\end{array}$ & $\begin{array}{c}\text { INDICE } \\
\text { REAL }\end{array}$ & $\begin{array}{l}\text { TAXA DE } \\
\text { CRESC. }\end{array}$ & $\begin{array}{c}\text { INDICE } \\
\text { REAL }\end{array}$ & $\begin{array}{c}\text { TAXA DE } \\
\text { CRESC. }\end{array}$ \\
\hline 69 & 100 & 0 & 100 & 0 & 100 & 0 \\
70 & 86 & -13 & 85 & -14 & 103 & 3 \\
71 & 95 & 10 & 73 & -13 & 107 & 4 \\
72 & 113 & 18 & 89 & 20 & 117 & 8 \\
73 & 150 & 32 & 124 & 40 & 228 & 95 \\
74 & 249 & 65 & 195 & 56 & 294 & 28 \\
75 & 372 & 49 & 223 & 14 & 360 & 22 \\
76 & 513 & 37 & 258 & 15 & 375 & 4 \\
\hline
\end{tabular}

\begin{tabular}{|c|c|c|c|c|c|c|}
\hline & \multicolumn{2}{|c|}{ ESPIRITO SANTO } & \multicolumn{2}{|c|}{ RIO DE JANEIRO } & \multicolumn{2}{|c|}{ PARANA } \\
\hline & $\begin{array}{c}\text { INDICE } \\
\text { REAL }\end{array}$ & $\begin{array}{l}\text { TAXA DE } \\
\text { CRESC. }\end{array}$ & $\begin{array}{c}\text { INDICE } \\
\text { REAL }\end{array}$ & $\begin{array}{l}\text { TAXA DE } \\
\text { CRESC. }\end{array}$ & $\begin{array}{c}\text { INDICE } \\
\text { REAL }\end{array}$ & $\begin{array}{l}\text { TAXA DE } \\
\text { CRESC. }\end{array}$ \\
\hline 69 & 100 & 0 & 100 & 0 & 100 & 0 \\
\hline 70 & 108 & 8 & 102 & 2 & 105 & 5 \\
\hline 71 & 101 & -5 & 107 & 4 & 103 & -1 \\
\hline 72 & 105 & 3 & 87 & -18 & 142 & 37 \\
\hline 73 & 180 & 79 & 167 & 91 & 287 & 101 \\
\hline 74 & 379 & 110 & 297 & 77 & 353 & 23 \\
\hline 75 & 449 & 18 & 326 & 9 & 472 & 33 \\
\hline 76 & 517 & 15 & 444 & 36 & 409 & -13 \\
\hline
\end{tabular}


TABELA 1 - Continuação - Preço da terra de lavoura - 17 Estados. dez. 69 $=100$

\begin{tabular}{cccccccc}
\hline & \multicolumn{2}{c}{ SANTA } & CATARINA & RIO GRANDE DO SUL & \multicolumn{2}{c}{ MATO GROSSO } \\
\cline { 2 - 7 } & $\begin{array}{c}\text { INDICE } \\
\text { REAL }\end{array}$ & $\begin{array}{c}\text { TAXA DE } \\
\text { CRESC. }\end{array}$ & $\begin{array}{c}\text { INDICE } \\
\text { REAL }\end{array}$ & $\begin{array}{c}\text { TAXA DE } \\
\text { CRESC. }\end{array}$ & $\begin{array}{c}\text { INDICE } \\
\text { REAL }\end{array}$ & $\begin{array}{c}\text { TAXA DE } \\
\text { CRESC. }\end{array}$ \\
\hline 69 & 100 & 0 & 100 & 0 & 100 & 0 \\
70 & 100 & 0 & 118 & 18 & 101 & 1 \\
71 & 101 & 1 & 126 & 5 & 102 & 0 \\
72 & 109 & 7 & 150 & 19 & 139 & 36 \\
73 & 126 & 16 & 265 & 75 & 247 & 77 \\
74 & 232 & 83 & 349 & 31 & 444 & 79 \\
75 & 283 & 24 & 428 & 22 & 388 & -12 \\
76 & 312 & 8 & 474 & 10 & 334 & -13 \\
& & & & & & \\
\hline
\end{tabular}

\begin{tabular}{lrccc}
\hline & \multicolumn{2}{c}{ GOIAS } & \multicolumn{2}{c}{ SÃO PAULO } \\
\cline { 2 - 5 } & $\begin{array}{c}\text { INDICE } \\
\text { REAL }\end{array}$ & $\begin{array}{c}\text { TAXA DE } \\
\text { CRESC. }\end{array}$ & $\begin{array}{c}\text { INDICE } \\
\text { REAL }\end{array}$ & $\begin{array}{c}\text { TAXA DE } \\
\text { CRESC. }\end{array}$ \\
\hline 69 & 100 & 0 & 100 & 0 \\
70 & 85 & -14 & 119 & 19 \\
71 & 84 & -0 & 129 & 8 \\
72 & 119 & 41 & 188 & 45 \\
73 & 192 & 60 & 386 & 104 \\
74 & 284 & 48 & 392 & 1 \\
75 & 268 & -5 & 459 & 16 \\
76 & 237 & -11 & 473 & 3 \\
\hline
\end{tabular}

Fonte: Agropecuāria - F.G.V. 
TABELA 2 - Ocupação da fronteira em ha - 17 Estados - 1970 e 1975

\begin{tabular}{lrrrrrr}
\hline & \multicolumn{2}{c}{ AREA LAVOURA } & TAXA DE & \multicolumn{2}{c}{ AREA TOTAL } & \multicolumn{1}{c}{ TAXA DE } \\
\cline { 2 - 3 } & \multicolumn{1}{c}{1970} & 1975 & CRESC. & \multicolumn{1}{c}{1970} & 1975 & ANESC. \\
\hline MA & 763.305 & 1.066 .612 & 6,9 & 4.116 .082 & 4.875 .447 & 3,4 \\
CE & 1.134 .503 & 2.239 .700 & 13,6 & 5.228 .315 & 5.842 .148 & 2,2 \\
RN & 771.895 & 835.586 & 1,6 & 2.676 .711 & 2.503 .477 & $-1,3$ \\
PB & 1.181 .862 & 1.185 .262 & 0,1 & 3.238 .458 & 3.154 .512 & $-0,5$ \\
PE & 1.472 .734 & 1.674 .384 & 7,2 & 3.858 .279 & 4.392 .301 & 2,6 \\
AL & 571.705 & 789.832 & 6,7 & 1.267 .562 & 1.559 .701 & 4,2 \\
SE & 202.382 & 245.326 & 3,9 & 1.219 .682 & 1.413 .889 & 3,0 \\
BA & 2.363 .444 & 2.869 .474 & 4,0 & 11.429 .049 & 14.088 .616 & 4,3 \\
MG & 3.542 .477 & 4.146 .128 & 3,2 & 33.259 .049 & 36.095 .410 & 1,6 \\
ES & 693.539 & 690.054 & $-0,1$ & 2.523 .514 & 2.820 .617 & 2,2 \\
RJ & 637.464 & 644.413 & 0,2 & 2.366 .794 & 2.503 .451 & 1,1 \\
SP & 4.735 .925 & 5.928 .502 & 2,2 & 16.199 .308 & 16.645 .403 & 0,5 \\
PR & 4.718 .606 & 5.859 .167 & 4,4 & 9.228 .316 & 10.842 .007 & 3,3 \\
SC & 1.331 .676 & 1.729 .306 & 5,4 & 3.799 .661 & 4.136 .335 & 1,7 \\
RS & 4.978 .173 & 6.271 .239 & 4,7 & 19.613 .159 & 20.044 .127 & 0,4 \\
MT & 753.749 & 1.847 .166 & 19,6 & 32.342 .052 & 33.884 .131 & 0,9 \\
G0 & 1.636 .170 & 2.665 .485 & 10,2 & 25.421 .352 & 31.829 .648 & 4,5 \\
& & & & & & \\
\hline
\end{tabular}

Fonte: Censos Agropecuārios - 1970 e 1975. 
TABELA 3 - Preço médio da terra - Brasil - 70 a 79

\begin{tabular}{lcc}
\hline & \multicolumn{2}{c}{ MEDIA BRASIL } \\
\cline { 2 - 3 } 70 & Cr\$/ha DE 1977 & TAXA DE CRESCIMENTO (\%) \\
\hline 71 & $3.042,17$ & 3,9 \\
72 & $3.161,39$ & 27,5 \\
73 & $4.030,04$ & 87,4 \\
74 & $7.552,01$ & 20,0 \\
75 & $9.065,38$ & 20,0 \\
76 & $10.870,38$ & 3,1 \\
77 & $11.206,13$ & $-3,2$ \\
78 & $10.852,10$ & 5,1 \\
79 & $11.405,91$ & 8,0 \\
\hline
\end{tabular}

Fonte: Agropecuāria - F.G.V. 
TABELA 4 - Crédito total real concedido à Agropecuāria para 17 Estados Dez. $69=100$

\begin{tabular}{|c|c|c|c|c|c|c|}
\hline & \multicolumn{2}{|c|}{ MARANHÃO } & \multicolumn{2}{|c|}{ CEARA } & \multicolumn{2}{|c|}{ RIO GRANDE DO NORTE } \\
\hline & $\begin{array}{l}\text { INDICE } \\
\text { REAL }\end{array}$ & $\begin{array}{l}\text { TAXA DE } \\
\text { CRESC. }\end{array}$ & $\begin{array}{c}\text { INDICE } \\
\text { REAL }\end{array}$ & $\begin{array}{l}\text { TAXA DE } \\
\text { CRESC. }\end{array}$ & $\begin{array}{l}\text { INDICE } \\
\text { REAL }\end{array}$ & $\begin{array}{l}\text { TAXA DE } \\
\text { CRESC. }\end{array}$ \\
\hline 69 & 100 & 0 & 100 & 0 & 100 & 0 \\
\hline 70 & 93 & -7 & 79 & -27 & 62 & -38 \\
\hline 71 & 154 & 65 & 131 & 65 & 127 & 104 \\
\hline 72 & 136 & 21 & 169 & 29 & 151 & 19 \\
\hline 73 & 281 & 51 & 221 & 31 & 201 & 33 \\
\hline 74 & 246 & -22 & 284 & 29 & 260 & 29 \\
\hline 75 & 546 & 122 & 362 & 27 & 439 & 69 \\
\hline 76 & 540 & -1 & 500 & 38 & 497 & 13 \\
\hline
\end{tabular}

\begin{tabular}{ccccccc}
\hline & \multicolumn{2}{c}{ PARAIBA } & \multicolumn{2}{c}{ PERNAMBUCO } & \multicolumn{2}{c}{ ALAGOAS } \\
\cline { 2 - 7 } & $\begin{array}{c}\text { INDICE } \\
\text { REAL }\end{array}$ & $\begin{array}{c}\text { TAXA DE } \\
\text { CRESC. }\end{array}$ & $\begin{array}{c}\text { INDICE } \\
\text { REAL }\end{array}$ & $\begin{array}{c}\text { TAXA DE } \\
\text { CRESC. }\end{array}$ & $\begin{array}{c}\text { INDICE } \\
\text { REAL }\end{array}$ & $\begin{array}{c}\text { TAXA DE } \\
\text { CRESC. }\end{array}$ \\
\hline 69 & 100 & 0 & 100 & 0 & 100 & 0 \\
70 & 67 & -33 & 105 & 5 & 103 & 22 \\
71 & 139 & 107 & 155 & 47 & 103 & -11 \\
72 & 113 & -15 & 179 & 16 & 134 & 37 \\
73 & 176 & 49 & 220 & 23 & 192 & 38 \\
74 & 234 & 33 & 210 & -4 & 284 & 63 \\
75 & 333 & 44 & 320 & 57 & 503 & 78 \\
76 & 395 & 17 & 333 & 4 & 489 & -5 \\
\hline
\end{tabular}


TABELA 4 - Continuação - Crédito concedido

\begin{tabular}{crrrrrr}
\hline & \multicolumn{2}{c}{ SERGIPE } & \multicolumn{2}{c}{ BAHIA } & \multicolumn{2}{c}{ MINAS GERAIS } \\
\cline { 2 - 7 } & $\begin{array}{c}\text { INDICE } \\
\text { REAL }\end{array}$ & $\begin{array}{c}\text { TAXA DE } \\
\text { CRESC. }\end{array}$ & $\begin{array}{c}\text { INDICE } \\
\text { REAL }\end{array}$ & $\begin{array}{l}\text { TAXA DE } \\
\text { CRESC. }\end{array}$ & $\begin{array}{c}\text { INDICE } \\
\text { REAL }\end{array}$ & $\begin{array}{c}\text { TAXA DE } \\
\text { CRESC。 }\end{array}$ \\
\hline 69 & 100 & 0 & 100 & 0 & 100 & 0 \\
70 & 80 & -20 & 101 & 1 & 125 & 25 \\
71 & 100 & 25 & 118 & 17 & 130 & 3 \\
72 & 196 & 96 & 127 & 8 & 160 & 23 \\
73 & 203 & 4 & 134 & 45 & 257 & 57 \\
74 & 271 & 33 & 266 & 44 & 313 & 24 \\
75 & 346 & 23 & 454 & 70 & 416 & 33 \\
76 & 334 & -4 & 502 & 11 & 432 & 4 \\
\hline
\end{tabular}

\begin{tabular}{ccccccc}
\hline & \multicolumn{2}{c}{ ESPIRITO SANTO } & \multicolumn{2}{c}{ RI0 DE } & JANEIRO & \multicolumn{2}{c}{ SÃO PAUL0 } \\
\cline { 2 - 7 } & $\begin{array}{c}\text { INDICE } \\
\text { REAL }\end{array}$ & $\begin{array}{c}\text { TAXA DE } \\
\text { CRESC. }\end{array}$ & $\begin{array}{c}\text { INDICE } \\
\text { REAL }\end{array}$ & $\begin{array}{l}\text { TAXA DE } \\
\text { CRESC. }\end{array}$ & $\begin{array}{c}\text { INDICE } \\
\text { REAL }\end{array}$ & $\begin{array}{c}\text { TAXA DE } \\
\text { CRESC。 }\end{array}$ \\
\hline 69 & 100 & 0 & 100 & 0 & 100 & 0 \\
70 & 124 & 24 & 105 & 5 & 120 & 20 \\
71 & 153 & 27 & 104 & -7 & 130 & 8 \\
72 & 180 & 13 & 90 & -13 & 150 & 15 \\
73 & 223 & 27 & 132 & 45 & 214 & 42 \\
74 & 295 & 29 & 178 & 35 & 246 & 15 \\
75 & 490 & 66 & 239 & 34 & 310 & 26 \\
76 & 510 & 4 & 215 & -10 & 292 & -6 \\
\hline
\end{tabular}


TABELA 4 - Continuação - Crédito concedido

\begin{tabular}{ccccccc}
\hline & \multicolumn{2}{c}{ PARANA } & \multicolumn{2}{c}{ SANTA CATARINA } & \multicolumn{2}{c}{ RIO GRANDE DO SUL } \\
\cline { 2 - 7 } & $\begin{array}{c}\text { INDICE } \\
\text { REAL }\end{array}$ & $\begin{array}{c}\text { TAXA DE } \\
\text { CRESC. }\end{array}$ & $\begin{array}{c}\text { INDICE } \\
\text { REAL }\end{array}$ & $\begin{array}{c}\text { TAXA DE } \\
\text { CRESC. }\end{array}$ & $\begin{array}{c}\text { INDICE } \\
\text { REAL }\end{array}$ & $\begin{array}{c}\text { TAXA DE } \\
\text { CRESC. }\end{array}$ \\
\hline 69 & 100 & 0 & 100 & 0 & 100 & 0 \\
70 & 143 & 43 & 132 & 32 & 122 & 22 \\
71 & 161 & 8 & 118 & -10 & 162 & 32 \\
72 & 237 & 47 & 161 & 36 & 192 & 19 \\
73 & 346 & 46 & 247 & 54 & 261 & 36 \\
74 & 444 & 28 & 392 & 59 & 329 & 26 \\
75 & 659 & 48 & 667 & 70 & 518 & 58 \\
76 & 669 & 2 & 717 & 7 & 507 & -2 \\
& & & & & & \\
\hline
\end{tabular}

\begin{tabular}{ccccc}
\hline & \multicolumn{2}{c}{ MATO GROSSO } & \multicolumn{2}{c}{ GOIASS } \\
\cline { 2 - 5 } & $\begin{array}{c}\text { INDICE } \\
\text { REAL }\end{array}$ & $\begin{array}{l}\text { TAXA DE } \\
\text { CRESC. }\end{array}$ & $\begin{array}{c}\text { INDICE } \\
\text { REAL }\end{array}$ & $\begin{array}{l}\text { TAXA DE } \\
\text { CRESC. }\end{array}$ \\
\hline 69 & 100 & 0 & 100 & 0 \\
70 & 122 & 22 & 99 & -7 \\
71 & 147 & 21 & 130 & 32 \\
72 & 276 & 88 & 171 & 32 \\
73 & 349 & 27 & 241 & 41 \\
74 & 422 & 21 & 329 & 36 \\
75 & 789 & 87 & 508 & 54 \\
76 & 1.036 & 31 & 537 & 6 \\
\hline
\end{tabular}


GRAFICO 1

Evolução do Indice Real de Crēdito para agropecuäria e do Indice Real do Preço da Terra em São Pau1o ${ }^{1}$

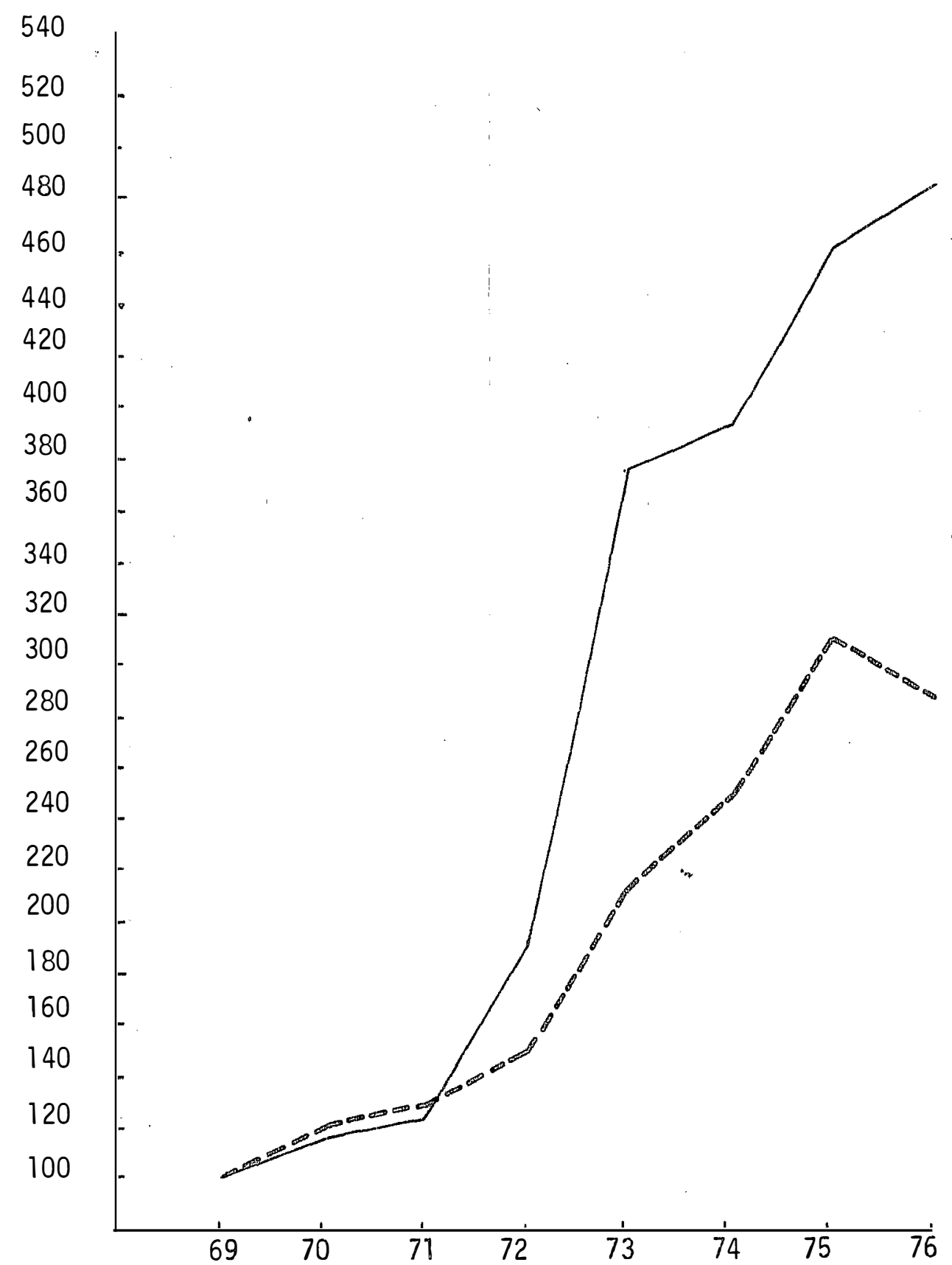

Indice do Preço da terra de lavoura em $\mathrm{Cr} \$ /$ ha

Indice do montante de crédito concedido à agropecuária em $\mathrm{Cr} \$$

${ }^{1}$ Cr\$ de 1977, deflacionado pelo Indice 2 da F.G.V. 
GRAFICO 2

Evolução do Indice Real de Crédito concedido à agropecuäria e do Indice Real do Preço da Terra em Alagoas ${ }^{1}$

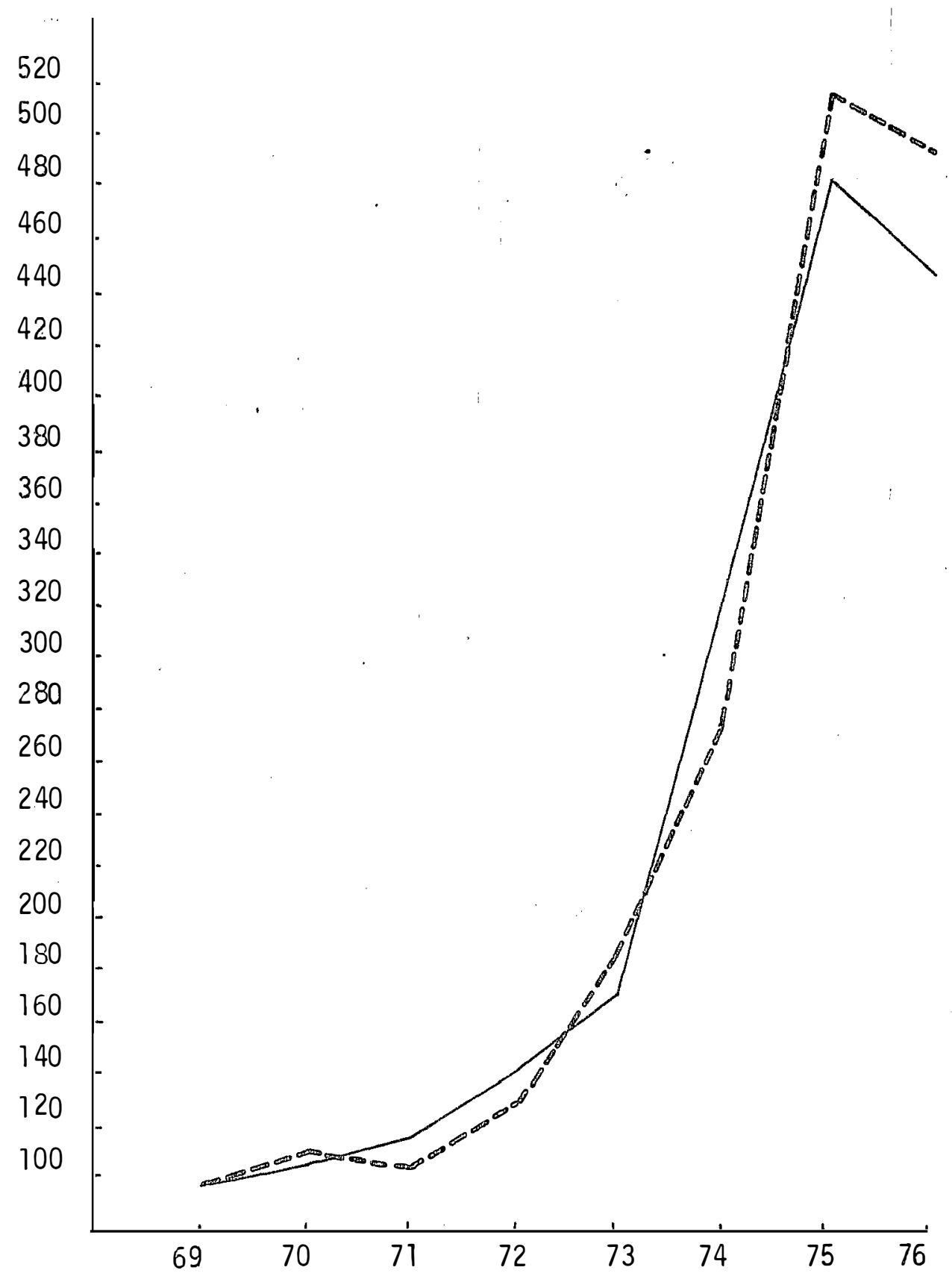

___ Indice do Preço da terra de lavoura em $\mathrm{cr} \$$

- Indice do montante de Crédito concedido à agropecuäria em $\mathrm{Cr} \$ / \mathrm{ha}$

${ }^{1}$ Cr\$ de 1977, deflacionado pelo Indice 2 da F.G.V. 


\section{GRAFICO 3}

Evolução do Indice Real de Crēdito concedido ā Agropecuāria e do Indice Real do Preço da Terra em Pernambuco ${ }^{1}$

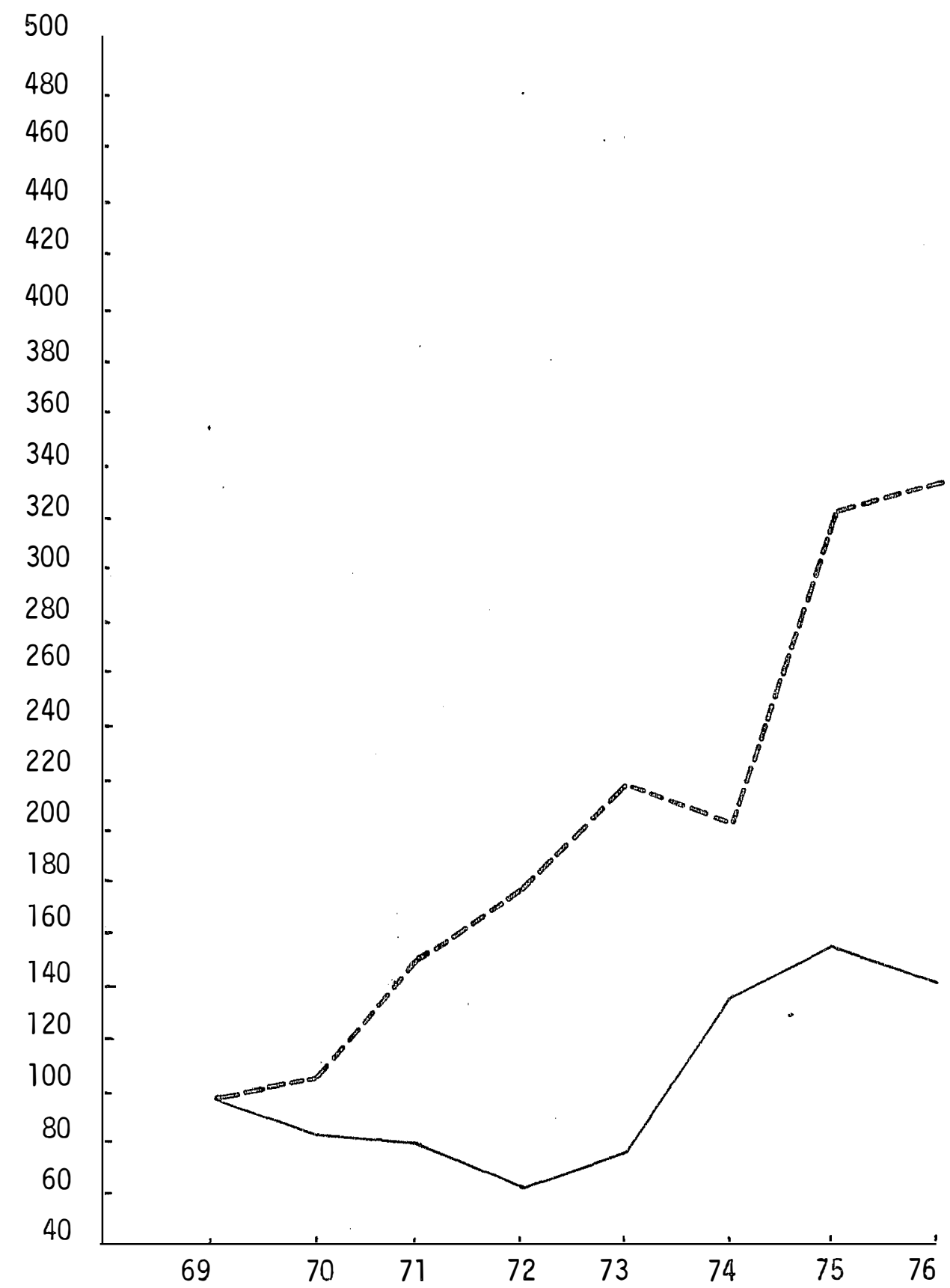

Indice do Preço da terra de lavoura em $\mathrm{Cr} \$$

Indice do montante de crédito concedido à agropecuāria Cr\$/ha

${ }^{1}$ Cr\$ 1977, deflacionado pelo Indice 2 da F.G.V. 
GRAFICO 4

Evolução do Indice Real do Crédi to à Agropecuāria e do Indice Real do Preço da Terra na Bahia ${ }^{1}$

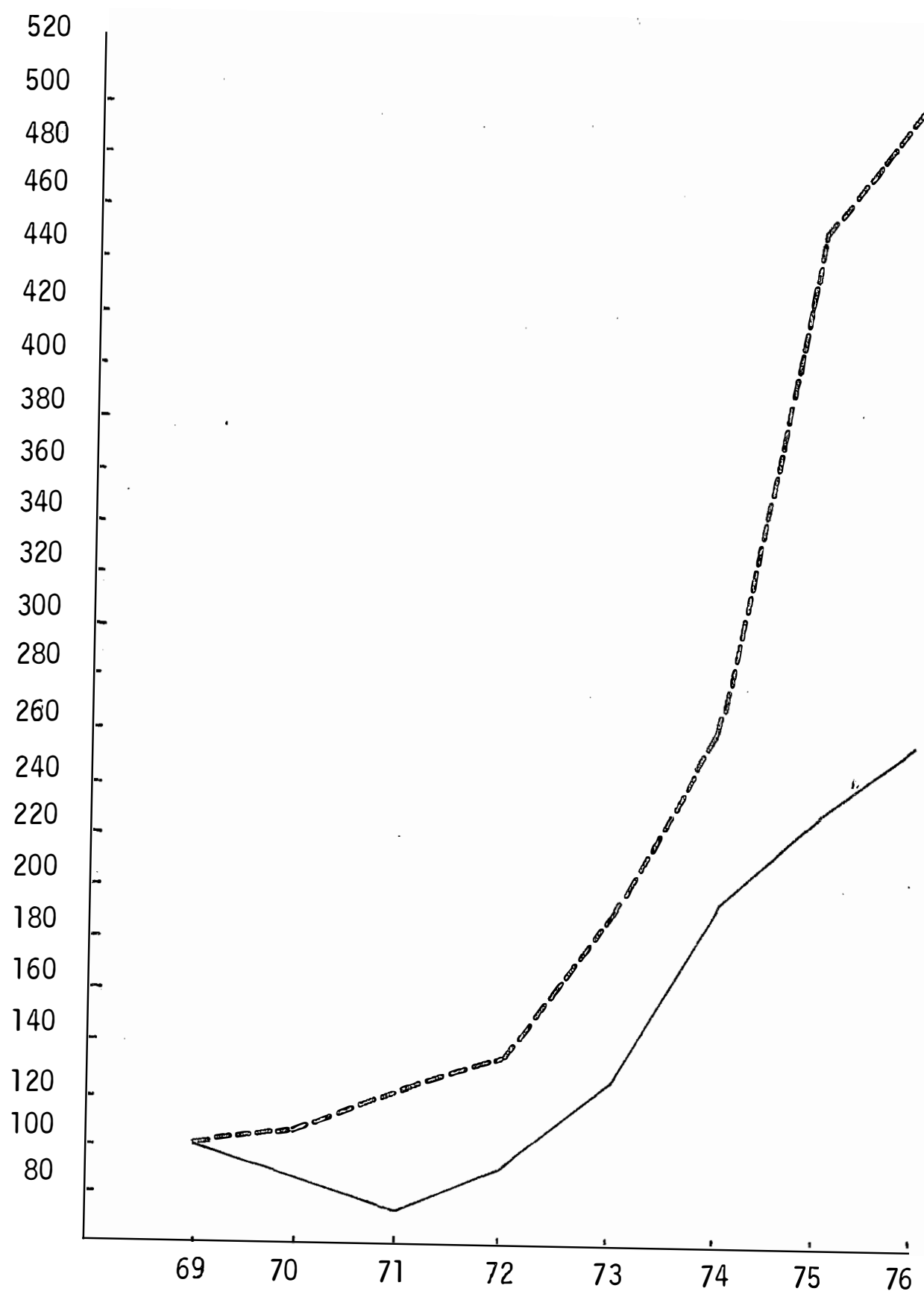

Indice do preço da terra de lavoura em $\mathrm{Cr} \$ /$ ha

Indice do montante do crédito concedido à agropecuāria Cr\$

${ }^{1}$ Cr\$ de 1977, deflacionado pelo Indice 2 da F.G.V. 